Karla Alejandra Vizcarra Zevallos

\title{
Análise da função de genes candidatos à manutenção da inativação do cromossomo $X$ em humanos
}

Dissertação apresentada ao Programa de Pós-Graduação Interunidades em Biotecnologia USP/ Instituto Butantan/ IPT, para obtenção do Título de Mestre em Ciências. 
Karla Alejandra Vizcarra Zevallos

\section{Análise da função de genes candidatos à manutenção da inativação do cromossomo $X$ em humanos}

Dissertação apresentada ao Programa de Pós-Graduação Interunidades em Biotecnologia do Instituto de Ciências Biomédicas USP/ Instituto Butantan/ IPT, para obtenção do Título de Mestre em Ciências.

Área de concentração: Biotecnologia

Orientadora: Profa. Dra. Lygia da Veiga Pereira Carramaschi

Versão corrigida. A versão original eletrônica encontra-se disponível tanto na Biblioteca do ICB quanto na Biblioteca Digital de Teses e Dissertações da USP (BDTD) 


\section{CATALOGAÇÃO NA PUBLICAÇÃO (CIP) \\ Serviço de Biblioteca e informação Biomédica \\ do Instituto de Ciências Biomédicas da Universidade de São Paulo}

Ficha Catalográfica elaborada pelo(a) autor(a)

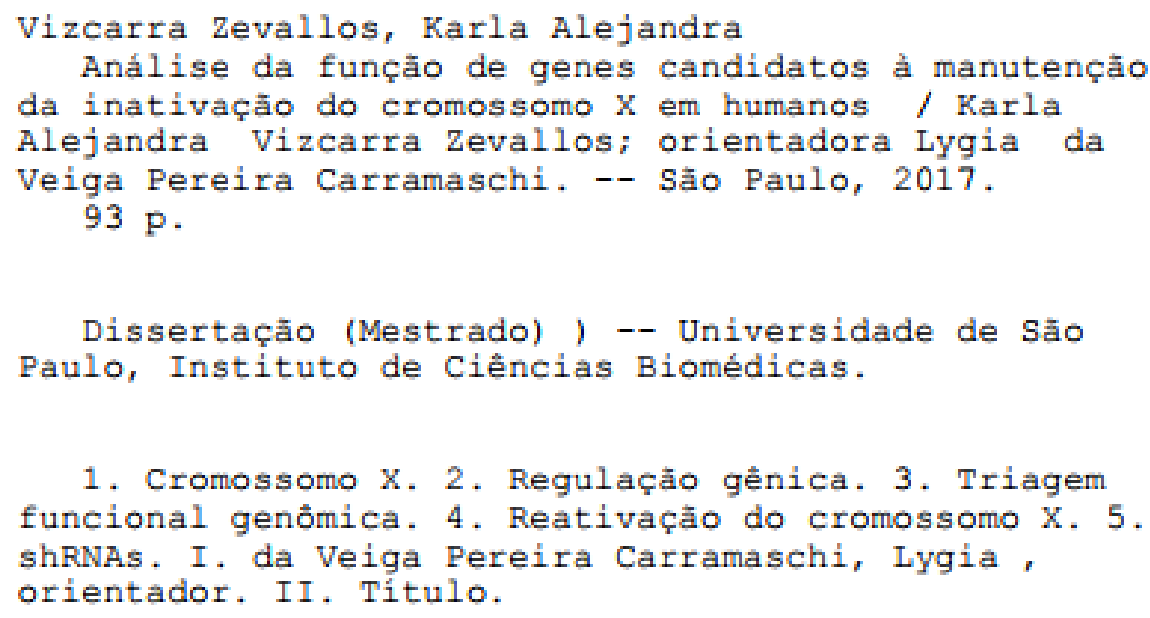

1. Cromossomo X. 2. Regulaçăo gểnica. 3. Triagem funcional genômica. 4. Reativaçăo do cromossomo X. 5 . shRNAs. I. da Veiga Pereira Carramaschi, Lygia, orientador. II. Título. 


\section{UNIVERSIDADE DE SÃO PAULO}

\section{Programa de Pós-Graduação Interunidades em Biotecnologia}

Universidade de São Paulo, Instituto Butantan, Instituto de Pesquisas Tecnológicas

Candidato(a): Karla Alejandra Vizcarra Zevallos

Título da Dissertação: Análise da função de genes candidatos à manutenção da inativação do cromossomo $\mathrm{X}$ em humanos

Orientador: Profa. Dra. Lygia da Veiga Pereira Carramaschi

A Comissão Julgadora dos trabalhos de Defesa da Dissertação de Mestrado, em sessão pública realizada a ............................., considerou o(a) candidato(a):

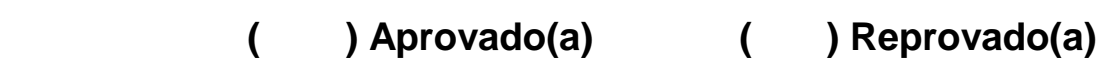

Examinador(a):

Assinatura:

Nome:

Instituição:

Examinador(a):

Assinatura:

Nome:

Instituição:

Examinador(a):

Assinatura:

Nome:

Instituição:

Presidente:

Assinatura:

Nome:

Instituição: 
A minha família pelo carinho, apoio e dedicação. 


\section{AGRADECIMENTOS}

Este trabalho não é fruto simplesmente do meu esforço pessoal, também é resultado da contribuição de muitas pessoas que colaboraram no meu desenvolvimento profissional e pessoal, direta ou indiretamente. Através destas linhas gostaria de mostrar meu agradecimento a todas elas.

A minha família por ser uma fonte infinita de amor e apoio nesse período longe de casa.

A minha orientadora Profa. Dra. Lygia da Veiga Pereira, por ter me aceitado como membro de seu laboratório. Pela confiança e as lições aprendidas.

Um agradecimento especial ao Luis, Simone, Luciana, Erica, Gustavo e Joana pela grande e constante ajuda, pela importante ajuda recebida nesse trabalho, pela pronta disponibilidade em discutir meus resultados, seu conhecimento foi fundamental para a interpretação em nossas análises.

À Profa. Dra. Ângela Maria Vianna Morgante pela importante ajuda recebida nesse trabalho. Agradeço também as queridas Mara e Fátima, sempre prontas a me socorrer técnica e emocionalmente.

À Doutora Fabiana Bentonni pela imensa ajuda, boa vontade e toda a paciência em me ensinar.

Aos meus colegas de laboratório: Juliana, Raquel, Lucas, Giselle, Isabela, Carol, Rodrigo, Fabiano, Gustavo, Mariana, Yordanka pela grande e constante ajuda, pela amizade de todo dia, pelos momentos de diversão e pelo carinho de vocês. Por todas aquelas risadas e carinho nestes últimos meses.

Aos meus amigos do grupo Hamutay - Young Peruvian Network for Bioscience Research, por ter me ensinado a importância de compartilhar o conhecimento e ter me dado a oportunidade de formar parte deste grande projeto. Pela confiança, amizade, e por ter me trazido um pouco do nosso país. Foi formidável poder contar com vocês. 
Aos meus amigos de infância, Tatiana, Sergio, Fernando e Elena por estar sempre comigo nesse tempo fora de casa. Por me fazer sentir que este tempo longe não reduziu o carinho entre nós.

Ao meu namorado, Fernando Salvador, meu profundo agradecimento pela força e companheirismo durante esse processo, por todo seu amor e sua paciência.

Às amizades que não foram mencionadas, mas que me acompanharam nestes dois anos longe de casa. Obrigada pelas conversas, brincadeiras, passeios, festas e comidas que animaram meus dias.

À Universidade de São Paulo (USP) pelo suporte estrutural. 
Agradeço à Fundação de Amparo à Pesquisa do Estado de São Paulo (FAPESP processo número 2014/26348-6) e o Conselho Nacional de Desenvolvimento Científico e Tecnológico (CNPq) pelo suporte financeiro concedido no âmbito do Programa de Excelência Acadêmica (PROEX) durante o período de fevereiro de 2015 a fevereiro de 2017. 
"Eu acredito demais na sorte.

E tenho constatado que, quanto mais duro eu trabalho, mais sorte eu tenho".

Thomas Jefferson 


\section{RESUMO}

Zevallos KA. Análise da função de genes candidatos à manutenção da inativação do cromossomo X em humanos. [Dissertação (Mestrado em Biotecnologia)] - Instituto de Ciências Biomédicas, Universidade de São Paulo, São Paulo; 2017.

A inativação do cromossomo $X$ (ICX) em fêmeas é um exemplo de regulação epigenética. $O$ silenciamento de um dos cromossomos $X$ leva à formação estável da heterocromatina facultativa através da aquisição de múltiplas modificações na cromatina que são mantidas nas subsequentes divisões celulares. Atualmente, algumas características epigenéticas associadas à manutenção da ICX têm sido descritas, contudo os mecanismos de ação e a identidade dos diferentes fatores envolvidos na manutenção da ICX ainda são desconhecidos ou pouco compreendidos. Nosso laboratório realizou uma triagem funcional genômica por bibliotecas de shRNAs (short harpin RNAs) para encontrar genes envolvidos na manutenção da ICX em humanos. A partir deste estudo foram identificados 20 novos genes candidatos a estarem envolvidos na manutenção da ICX. Assim, o objetivo deste trabalho foi validar o grau de envolvimento de dois destes genes candidatos (H3F3B e ASF1A) no processo de controle epigenético do cromossomo X. Para isto, foi realizado o silenciamento dos genes candidatos através da utilização de partículas lentivirais portando shRNAs específicos em fibroblastos primários femininos heterozigotos para uma mutação no gene HPRT e com desvio total de ICX, onde o único alelo normal do gene HPRT está no Xi. A reativação do Xi nestas células foi avaliada por cultivo das mesmas em meio HAT, que seleciona células HPRT+. Só sobreviveram os fibroblastos que foram silenciados para o gene H3F3B. Nestes, as células transduzidas com o shH3F3B.2 expressam o alelo selvagem do gene, presente no Xi, além do gene mutante. Ensaios de RNA-FISH e trimetilação de histonas foram feitos nessas células para avaliar a perda das marcas de cromatina inativa. Foi observada uma perda da nuvem de XIST nas células transduzidas com o shH3F3B.2 e selecionadas em HAT em passagens altas. Por último, análises de expressão alelo-específica de genes ligados ao $\mathrm{X}$ comprovaram que dois genes que são submetidos à ICX apresentaram expressão do alelo inativado (FLNA e FHL1). Porém, também foi observada uma mudança no padrão de expressão alelo-específica em genes autossômicos. Finalmente, as análises de expressão geral do cromossomo $\mathrm{X}$ mostraram que as células transduzidas com o shH3F3B.2 e selecionada em HAT tinham uma expressão gênica aumentada em relação ao controle. Em conclusão, nossos resultados sugerem uma descondensação da cromatina no cromossomo Xi e portanto um provável envolvimento do gene $H 3 F 3 B$ na manutenção da ICX.

Palavras-chave: Regulação gênica. Cromossomo X. Triagem funcional genômica. Reativação do cromossomo X. shRNAs. 


\section{ABSTRACT}

Zevallos KA. A functional analysis of candidate genes for the maintenance of $X$ chromosome inactivation in humans. [Masters thesis (Biotechnology)]. - Instituto de Ciências Biomédicas, Universidade de São Paulo, São Paulo; 2017.

The $\mathrm{X}$ chromosome Inactivation $(\mathrm{XCl})$ in females is an example of epigenetic regulation. Silencing of one of the $X$ chromosomes leads to the stable formation of the facultative heterochromatin through the acquisition of multiple modifications in the chromatin that are maintained in the subsequent cell divisions. Currently, some epigenetic features associated with the maintenance of $\mathrm{XCl}$ have been described. Nonetheless, the mechanisms of action and the identity of the different factors involved in the maintenance of $\mathrm{XCl}$ are still unknown or poorly understood. Our laboratory performed a genomic functional screening by shRNA (short harpin RNAs) libraries to find genes involved in the maintenance of $\mathrm{XCl}$ in humans. From this study, we identified 20 new candidate genes to be involved in the maintenance of XCl. Thus, the objective of this work was to validate the degree of involvement of two of these candidate genes (H3F3B and ASF1A) in the epigenetic process control of the $\mathrm{X}$ chromosome. For this, the silencing of the candidate genes was performed in female heterozygous primary fibroblasts for a mutation of the HPRT gene and with a total XCl shift through the use of lentiviral particles carrying specific shRNAs, where the only normal allele of the HPRT gene is in the $\mathrm{Xi}$ (inactivated $\mathrm{X}$ ). $\mathrm{Xi}$ reactivation was evaluated in these cells by culturing them in HAT medium, which selects HPRT + cells. Only the fibroblasts that were silenced for the H3F3B gene survived. Furthermore, the cells transduced with shH3F3B.2 express the HPRT wild gene allele, present in $\mathrm{Xi}$, in addition to the mutant gene. RNA-FISH and histone trimethylation assays were performed on these cells to evaluate the loss of inactive chromatin marks. A loss of the XIST cloud was observed in cells transduced with shH3F3B.2 and selected in HAT at high passages. Finally, allele-specific expression analyzes of $\mathrm{X}$-linked genes showed that two genes that undergo $\mathrm{XCl}$ showed expression of the inactivated allele (FLNA and FHL1). However, a change in allele-specific expression pattern was also observed in autosomal genes. Finally, the $X$ chromosome general expression analyses showed that cells transduced with shH3F3B.2 and selected on HAT had increased gene expression relative to the control. In conclusion, our results suggest a decondensation of the chromatin in the $\mathrm{Xi}$ chromosome and therefore a probable involvement of the $H 3 F 3 B$ gene in the maintenance of ICX.

Key words: Genic regulation. X chromosome. Functional Genomic Screening. X chromosome reactivation. shRNAs. 


\section{LISTA DE ABREVIATURAS}

\begin{tabular}{|c|c|}
\hline 6TG & 6-tioguanina \\
\hline$A C T B$ & Beta Actina \\
\hline ASF1A & Anti-Silencing Function 1A Histone Chaperone gene \\
\hline ATF7IP & Activating Transcription Factor 7 Interacting (Proteina \\
\hline ATRX & Alpha Thalassemia/Mental Retardation Syndrome $X$ gene \\
\hline BSA & Bovine Serum Albumin (albumina do soro bovino) \\
\hline Cat\# & Número de catálogo \\
\hline cDNA & DNA complementar \\
\hline CDYL & Chromodomain Y-Like (proteína de cromodominio Y-Like) \\
\hline Chr. & Cromossomo \\
\hline $\mathrm{CO}_{2}$ & dióxido de carbono \\
\hline CTCF & CCCTC-binding factor \\
\hline DAPI & 4',6-diamidino-2-phenylindole \\
\hline ddPCR & Digital Droplet PCR (PCR digital) \\
\hline DEPC & diethylpyrocarbonate (dicarbonato de dietila) \\
\hline DMEM & Dulbecco's Modified Eagle Medium \\
\hline DMSO & Dimetilsulfóxido \\
\hline DNA & Ácido dexoxirribonucléico \\
\hline DNMT1 & DNA Methyltransferase 1 \\
\hline DNMT3A & DNA Methyltransferase 3 Alpha \\
\hline DNMT3B & DNA Methyltransferase 3 Beta \\
\hline dNTP & Desoxirribonucleotídeo trifosfato \\
\hline DPBS & Dulbecco's Phosphate-Buffered Saline \\
\hline EDTA & Ácido etilenodinitrotetracético \\
\hline EED & $\begin{array}{l}\text { embrionicaEmbryonic Ectoderm Development protein } \\
\text { (Proteína de deenvolvimento da ectoderme) }\end{array}$ \\
\hline ESALQ & Escola Superior de Agricultura "Luiz de Queiroz" \\
\hline ESC & Embryonic stem cell (células tronco-embrionárias) \\
\hline
\end{tabular}


FBS Fetal bovine serum (soro fetal bovino)

FBS-ES Fetal Bovine Serum, embryonic stem cell-qualified (soro fetal bovino para células-tronco)

FHL1 Four And A Half LIM Domains 1 gene

Firre $\quad$ Functional Intergenic Repeating RNA Element gene

FLNA Filamin A gene

G9a Euchromatic histone-lysine N-methyltransferase 2 protein

GFP Green fluorescent protein (proteína verde fluorescente)

H2AK119ub Proteína H2A monoubiquitinada na lisina 119

H3.3 Histona 3, familia 3

H3F3B H3 Histone Family Member 3B

H3K27me3 Histona 3 trimetilada na lisina 27

H3K9me2 Histona 3 dimetilada na lisina 9

H3K9me3 Histona 3 trimetilada na lisina 9

H4 Histona 4

H4K20me1 Histona 4 monometilada na lisina 20

H4K20me3 Histona 4 trimetilada na lisina 20

HAT Hipoxantina, Aminopterina e timidina

HBiX1 Proteína que se liga a HP1

HDAC1 Histona desacetilase 1

HEK293T Linhagem celular humana derivada de HEK293 com expressão de antigen $\mathrm{T}$

Hg19 Genoma Referência Humano do UCSC

hiPSC human induced pluripotent cell (células-tronco pluripotentes induzidas humanas)

HIRA Histone Cell Cycle Regulator (Histona reguladora do ciclo celular)

HnRNPU Ribonucleoproteína nuclear heterogênea U

HP1 Proteína de Heterocromatina 1

HPRT Hypoxanthine guanine phosphoribosyl transferase

ICX Inativação do Cromossomo X

IgG Imunoglobulina $G$

JPX Just Proximal to XIST gene 
InRNA long non-coding RNA (RNA não-codificador longo)

macroH2A H2A histone isoform

MBD1 Methyl-CpG-binding domain protein 1

MEF mouse embryo fibroblast (fibroblasto embrionário de camundongo)

$\mathrm{MgCl} 2 \quad$ Cloreto de magnésio

MOI Multiplicity of infection (multiplicidade de infecção)

mRNA RNA mensageiro

MUT Mutante

NEAA Non-Essential Amino Acid (amino ácidos não essenciais)

NGS Next generation sequencing (sequenciamento de próxima geração)

PARs Regiões pseudo-autossômicas do X

$\mathrm{pb} \quad$ Pares de base

PBS phosphate buffered saline (Tampão fosfato-salino)

PCNA Proteína antígeno de proliferação celular nuclear

PCR Reação em cadeia da polimerase

qPCR PCR quantitativo

Ring1b Ring Finger Protein 1b protein

RNA Pol. II RNA polimerase II

RNA Ácido ribonucleico

RNA-FISH Hibridização fluorescente in situ de RNA

RNA-Seq Sequenciamento de RNA

RNF12 Ring Finger Protein, LIM Domain Interacting

RT room temperature (Temperatura ambiente)

RT-PCR reverse transcription polimerase chain reaction (reação de transcriptase reversa seguida de uma $\mathrm{PCR}$ )

SAHF senescence-associated heterochromatic foci

SETDB1 Proteína de dominio SET bifucardo 1

shRNA Short hairpin RNA

SMCHD1 Structural Maintenance Of Chromosomes Flexible Hinge Domain Containing protein

SNP Single nucleotide polymorphism (polimorfismo de base única) 


\begin{tabular}{|c|c|}
\hline SRF & Familia de proteínas reguladoras de splicing \\
\hline$S R Y$ & sex-determining region Y gene \\
\hline SSC & saline-sodium citrate buffer (Tampón salino de citrato de sódio) \\
\hline SYAP1 & Synapse Associated Protein 1 \\
\hline TBP & TATA-Box Binding Protein \\
\hline Tm & melting temperature temperature de fusão \\
\hline TPM & transcritos por milhão \\
\hline TRC2 & vetor scrmable \\
\hline TRC2-GFP & vetor scramble com GFP \\
\hline Tris & Tris (hidroximetil) aminometano \\
\hline Tsix & X-Inactivation-Specific Transcript-Antisense \\
\hline$U$ & Unidade \\
\hline USP & Universidade de São Paulo \\
\hline VAR & Variante do alelo \\
\hline WT & wild type (tipo selvagem) \\
\hline $\mathrm{X} 0$ & $\begin{array}{l}\text { Condição na qual a fêmea tem ausência parcial ou complete de um } \\
\text { Cromossomo X }\end{array}$ \\
\hline $\mathrm{Xa}$ & Cromossomo $\mathrm{X}$ ativo \\
\hline$X A C T$ & $X$ active specific transcript \\
\hline$X G$ & Xg Blood Group gene \\
\hline $\mathrm{Xi}$ & Cromossomo $\mathrm{X}$ inativo \\
\hline $\mathrm{XIC}$ & Centro de inativação do cromossomo $X$ \\
\hline XIST & $X$-inactive specific transcript \\
\hline YY1 & Proteína Yin Yang 1 \\
\hline
\end{tabular}




\section{LISTA DE FIGURAS}

Figura 1 - Inativação do cromossomo X em humanos ........................................22

Figura 2 - Esquema representativo da regulação do processo de ICX - Iniciação ....24 Figura 3 - Esquema representativo da regulação do processo de ICX - Manutenção

Figura 4 - Esquematização das etapas experimentais desenvolvidas durante a triagem funcional de genes envolvidos na manutenção da $\mathrm{XCl}$ em humanos ... .30

Figura 5 - Quantificação relativa por qPCR da expressão de ASF1A em células HEK293T transduzidas com lentivirus para produção de diferentes shRNAs

Figura 6 - Quantificação relativa por qPCR da expressão de ASF1A em células GM1661 transduzidas com lentivirus para produção de shRNAs

Figura 7- Células transduzidas com o shASF1A.1 no décimo segundo dia de cultivo em HAT $1,5 x$

Figura 8 - Quantificação relativa por qPCR da expressão de H3F3B em células HEK293T transduzidas com lentivirus para produção de diferentes shRNAs

Figura 9 - Quantificação relativa por qPCR da expressão de H3F3B em células GM1661 transduzidas com lentivirus para produção de dois diferentes shRNAs. ....51 Figura 10 - Células transduzidas com o shH3F3B.2 no décimo segundo dia de cultivo em HAT $1,5 \mathrm{x}$

Figura 11 - Avaliação da expressão de H3.3 por Imunofluorescência ...........................53

Figura 12 - Avaliação do acúmulo da H3K27me3 e exclusão da RNA Pol. II ...........54

Figura 13 - Avaliação da presença da nuvem de XIST por RNA-FISH (Teste 1) ......56

Figura 14 - Avaliação da presença da nuvem de XIST por RNA-FISH (Teste 2) ......57

Figura 15 - Quantificação relativa por qPCR da expressão de XIST em células GM1661 transduzidas com shH3F3B.2 ........................................................ 58

Figura 16 - Análise dos alelos do gene HPRT por RT-PCR ...............................59

Figura 17 - Avaliação da reativação do cromossomo $X$ através do gene HPRT .......60

Figura 18 - Avaliação da expressão alelo-específica do gene ATRX ......................62

Figura 19 - Genes informativos de expressão bialélica .....................................65

Figura 20 - Indução de expressão bialélica de genes nos cromossomos

autossômicos.

Figura 21 - Média móvel entre as amostras da linhagem GM1661

Figura 22 - Representação gráfica do grupo de genes com expressão aumentada na amostra de células transduzidas com shRNAs contra o gene candidato e selecionadas com HAT (S2) com relação a amostra controle (S3) 


\section{LISTA DE TABELAS}

Tabela 1 - Genes silenciados neste estudo 37

Tabela 2 - Lista de sondas Taqman utilizadas para técnica de RT-PCR em tempo real 40 Tabela 3 - Lista dos primers e sondas utilizadas para técnica de digital droplet PCR 44

Tabela 4 - Número de reads dos resultados de sequenciamento, de filtragem e dos alinhamentos 63

Tabela 5 - Porcentagem de variantes anotadas com expressão bialélica nos cromossomos autossômicos e cromossomos sexuais. 


\section{SUMARIO}

1 INTRODUÇÃO

1.1 Surgimento dos cromossomos sexuais .................................................20

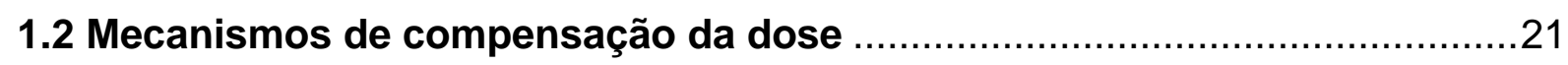

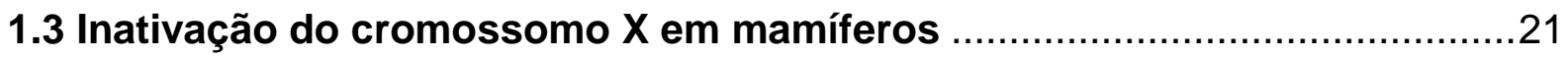

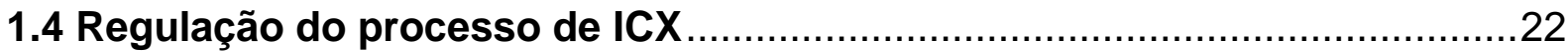

1.4.1 Iniciacão

1.4.2 Manutencão

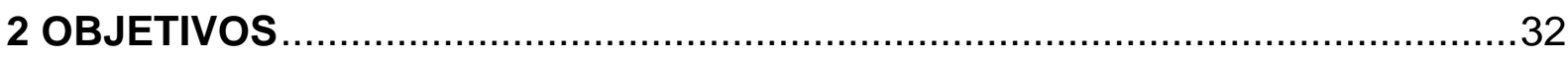

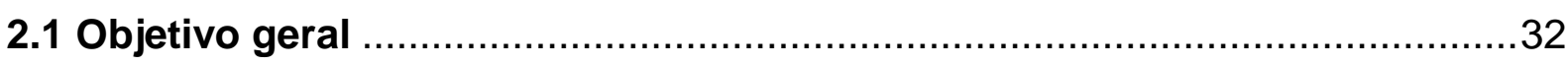

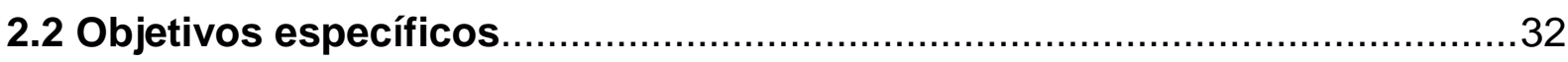

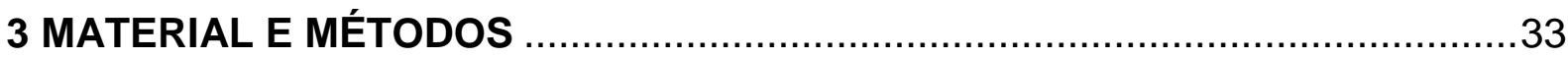

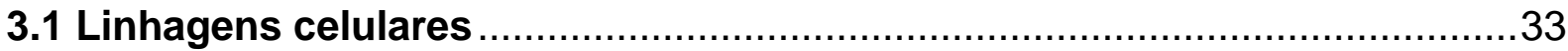

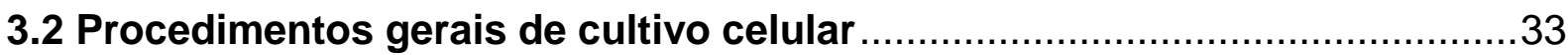

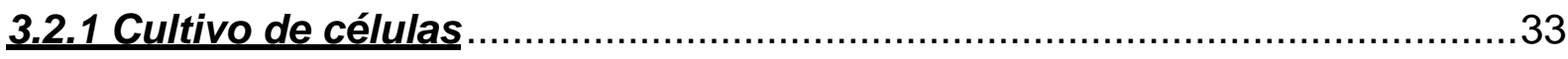

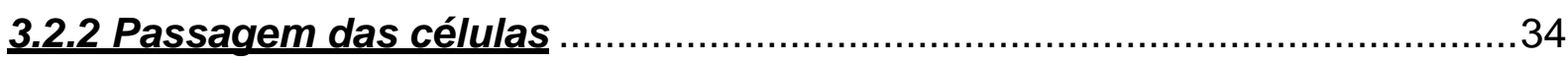

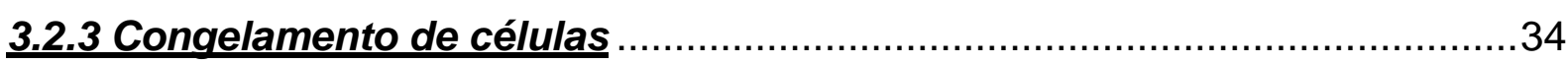

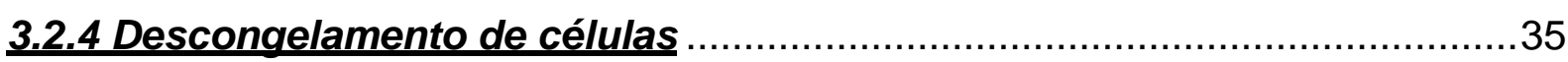

3.3 Seleção de células HPRT- na linhagem GM1661 ....................................35

3.4 Transdução das linhagens celulares GM1661 e HEK293T com shRNAs .....36

3.5 Seleção de células HPRT+ em fibroblastos primários humano_transduzidos 38

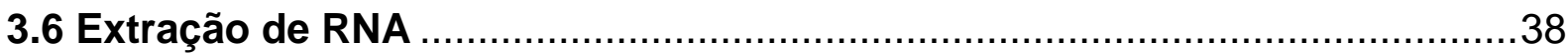

3.7 Síntese de cDNA

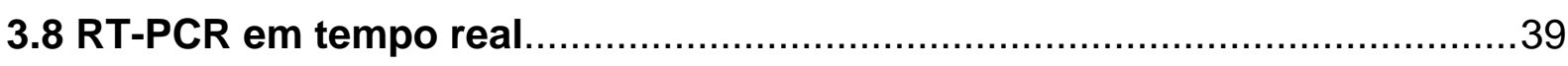

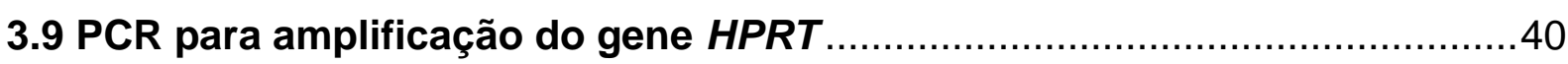

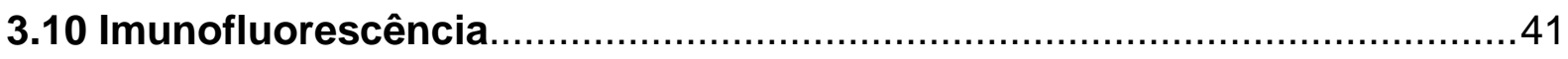

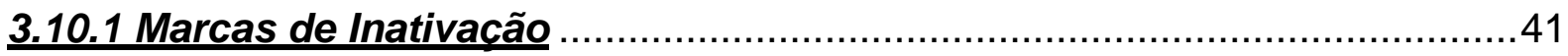

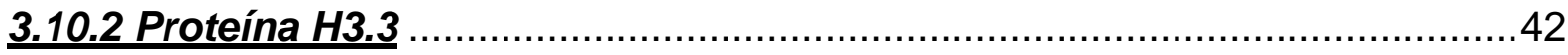

3.11 FISH de RNA

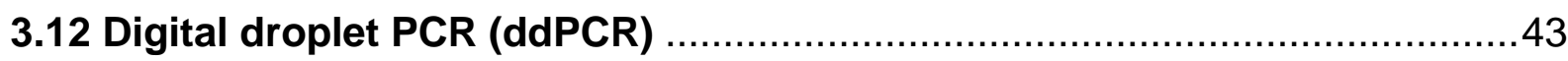

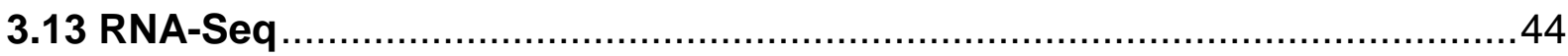

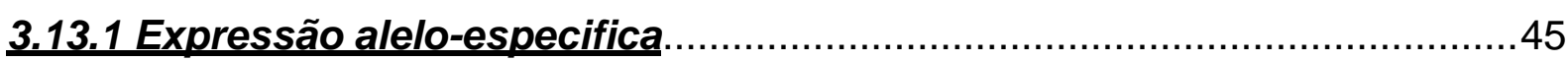

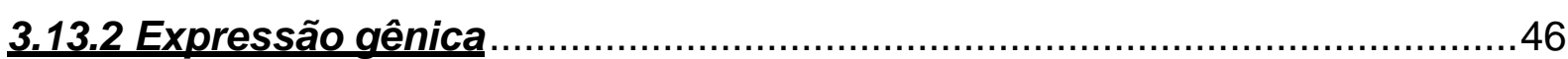

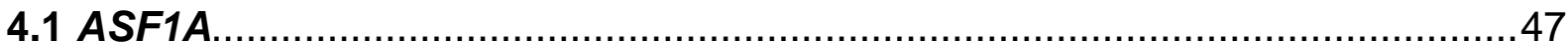


4.1.1 Validacão de shRNAs na linhagem HEK293T

4.1.2 Validacão de shRNAs escolhidos na linhagem GM1661 desviada .............48

4.1.3 Selecão de fibroblastos humanos primários HPRT+ ................................ 48

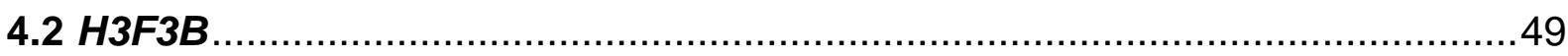

4.2.1 Validacão de shRNAs na linhagem HEK293T …........................................49

4.2.2 Validacão de shRNAs escolhidos na linhagem GM1661 desviada ............50

4.2.3 Selecão de fibroblastos humanos primários HPRT+ ...............................51

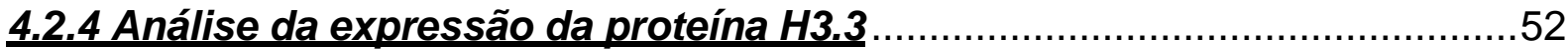

4.2.5.1 Análise das marcas de cromatina inativa ...........................................53

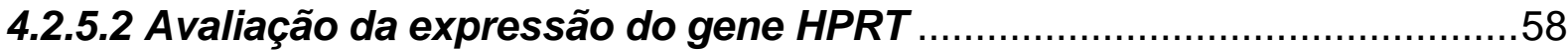

4.2.5.3 Avaliação da expressão alelo-específica no cromossomo $X$..................60

4.2.5.3.1 Avaliação da expressão alelo-específica do gene ATRX ..........................60

4.2.5.3.2 Avaliação da expressão alelo-específica ao longo do cromossomo $X$........63

4.2.5.3.3 Avaliação da expressão alelo-específica em cromossomos_autossômicos66

4.2.5.3.4 Avaliação dos níveis de expressão ao longo do cromossomo X.................68

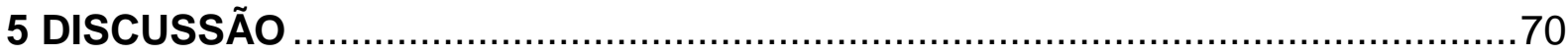

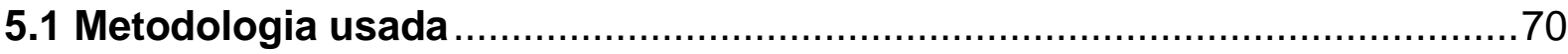

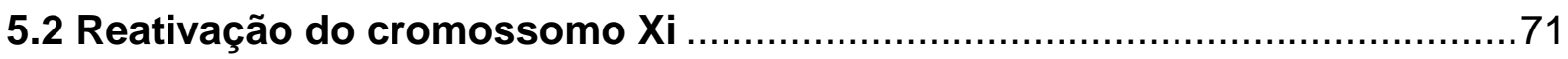

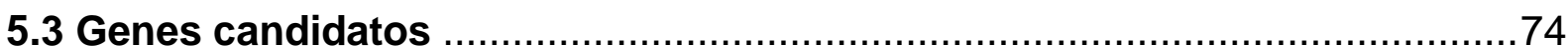

6 CONCLUSÕES

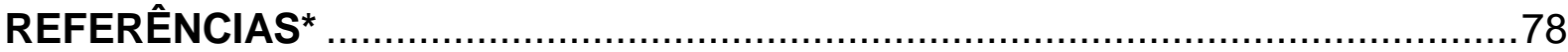

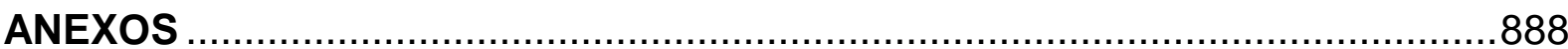

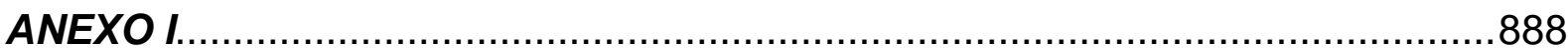

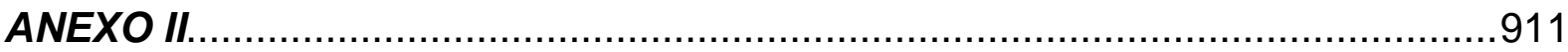

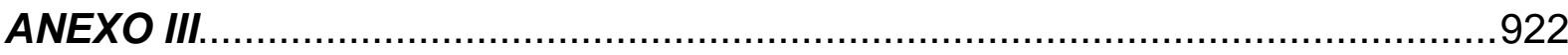




\section{INTRODUÇÃO}

\subsection{Surgimento dos cromossomos sexuais}

Em vertebrados gonocorísticos, existem dois mecanismos de determinação sexual, um dependente dos fatores ambientais e o outro dependente da informação genética (Conover, Heins, 1987). No primeiro mecanismo, o fato da prole ser macho ou fêmea é determinado por fatores ambientais, como a temperatura. Assim por exemplo, em tartarugas, baixas temperaturas no momento de incubação dos ovos produzem tartarugas machos, enquanto que altas temperaturas produzem tartarugas fêmeas (Bull, Vogt, 1979). No segundo mecanismo, o sexo é determinado pelo genótipo no momento da concepção e se dá com a presença dos cromossomos sexuais transmitidos pelas gametas parentais. Dentre os sistemas de cromossomos sexuais, o presente nos mamíferos placentários é o $\mathrm{XY}$, sendo que, a presença ou ausência do cromossomo $Y$ é o que determina a formação de gônadas masculinas ou femininas, respectivamente. Desse modo, as fêmeas são homogaméticas (XX) enquanto os machos são heterogaméticos (XY), havendo, portanto, cromossomos sexuais dismórficos, com uma grande diferença de tamanho entre eles: o cromossomo $X$ é bem maior e contém mais genes que o Y (Graves, 1995).

Segundo Muller et al. (1914) os cromossomos sexuais, X e Y, evoluíram a partir de um par de cromossomos autossômicos que depois divergiram, mais tarde foi proposto que um deles adquiriu uma mutação importante para a determinação do sexo, o gene SRY (Koopman, 1991), o qual levou a uma diminuição na recombinação das regiões homólogas durante a meiose e produziu uma rápida degradação do cromossomo Y (Charlesworth, 1991; Rice, 1996). Portanto, para poder se parear durante o processo de divisão celular, os cromossomos sexuais utilizam pequenas regiões homologas entre eles, as regiões pseudo-autossômicas (PARs) (Graves, 1995). 


\subsection{Mecanismos de compensação da dose}

A perda de genes no cromossomo $Y$ levou a uma haploinsuficiência funcional dos genes ligados ao cromossomo $\mathrm{X}$, o qual ficou essencialmente monossômico nos machos. Em geral, copias extras ou perda de cromossomos têm consequências prejudiciais na maioria de organismos eucarióticos diploides (Lindsley et al., 1972; Lee et al., 1996; Torres et al., 2007; Williams et al., 2008; Stingele et al., 2012). Por isso, a necessidade do desenvolvimento de mecanismos de compensação de dose dos cromossomos sexuais e autossômicos tem surgido ao longo do tempo em diferentes espécies para superar este problema (revisto em Ferrari et al., 2014).

Em mamíferos placentários, existem dois mecanismos de compensação gênica. O primeiro mecanismo é a inativação transcricional de um dos cromossomos $X$ femininos, que equipara a quantidade de transcritos do cromossomo $X$ entre machos (XY) e fêmeas (XX) (Lyon,1961). O segundo é a superexpressão do único $X$ ativo em ambos os sexos para compensar a quantidade de produtos gênicos entre cromossomos sexuais e autossômicos (Ohno,1967). Embora o primeiro mecanismo de compensação de dosagem seja bem estabelecido, a hipótese de Ohno ainda é debatida na literatura (Veitia et al., 2015).

\subsection{Inativação do cromossomo X em mamíferos}

A primeira evidencia registrada na literatura sobre a inativação do cromossomo X (ICX) veio de um trabalho publicado em 1949 por Barr e Bertram, no qual foi descrita uma estrutura nuclear fortemente marcada em células neurais de gatas, o corpúsculo de Barr. Anos mais tarde, algumas outras evidencias como o fato de indivíduos portadores da Síndrome de Klinefelter (47, XXY) apresentarem fenótipo masculino, ainda que possuem dois cromossomos $X$ (Jacobs, Strong, 1959) ou camundongos $X 0$ apresentarem fenótipo normal e serem férteis, mesmo tendo apenas um cromossomo X (Welshons, Russell, 1959), levaram Mary Frances Lyon a propor a hipótese de inativação do cromossomo X (Lyon, 1961). 
Atualmente, mais de 50 anos após a hipótese de Mary Lyon ter sido proposta, a inativação do cromossomo $X$ é considerada um exemplo clássico de regulação epigenética. Desta forma, em mamíferos placentários, a determinação de qual cromossomo X vai ser silenciado, se o paterno ou o materno, é aleatória (Lyon, 1961). Contudo, existem algumas exceções, como os tecidos extra-embrionários dos camundongos nos quais o X paterno sempre é inativado (Takagi; Sasaki, 1975). Uma vez estabelecida a ICX em uma célula, esta é mantida ao longo das múltiplas divisões das células descendentes. Assim, as fêmeas apresentam um fenótipo do tipo mosaico (Figura 1), pois as células do corpo se dividem em dois grupos - cada um expressando somente os genes de um dos dois cromossomos $X$ (Lyon, 1961, 1962).

\subsection{Regulação do processo de ICX}

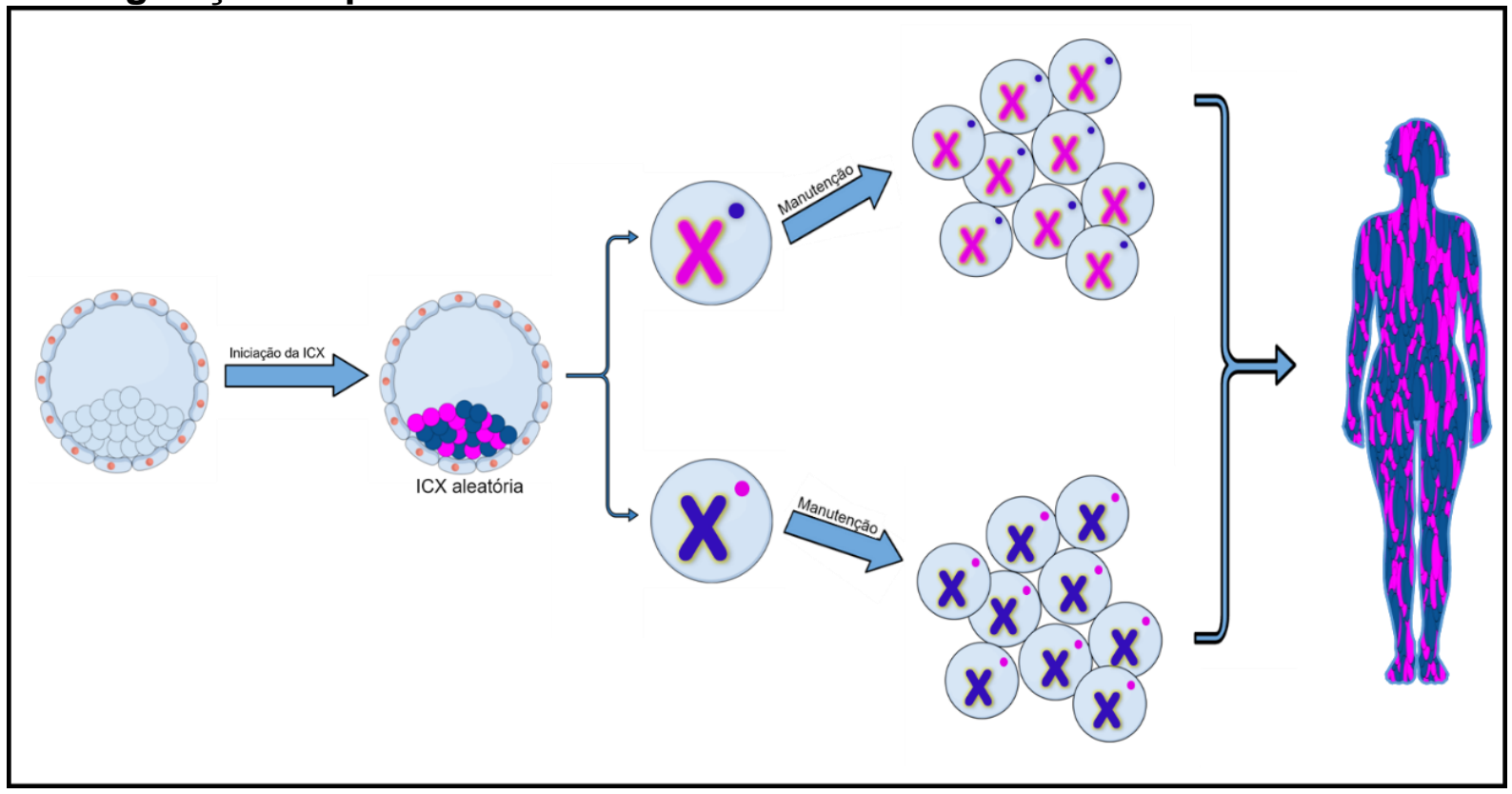

Figura 1 - Inativação do cromossomo $X$ em humanos. A inativação do cromossomo $X$ inicia-se cedo na embriogênese. Em humanos, a seleção do $X$ a ser inativado em cada uma das células somáticas é aleatória, assim, pode ser inativado tanto o X paterno (azul) como o X materno (rosa). Uma vez que um dos cromossomos é selecionado para ser inativado em uma célula, todas as células-filhas desta terão o mesmo X inativo. Isto torna as mulheres um mosaico em relação à expressão dos genes do cromossomo X. Fonte: Modificado de Morey e Avner, 2010.

Este é um processo constituído por vários mecanismos que podem ser agrupados principalmente em duas fases: Iniciação e manutenção (Kalantry, 2011).

\subsubsection{Iniciacão}


A iniciação da ICX é controlada a partir de uma região mínima necessária no cromossomo X para desencadeá-la, o centro de inativação do cromossomo X (XIC) (Brown et al., 1991). O processo de ICX começa com a contagem do número de cromossomos $X$ em relação ao número de autossomos, onde só um cromossomo $X$ permanece ativo por cada conjunto diplóide. Em seguida, vem a escolha de qual cromossomo $X$ será inativado (Kay et al., 1993). Após a escolha, o gene XIST (Xinactive specific transcript), localizado no XIC, que transcreve um RNA longo não traduzido (IncRNA), passa a ser expresso a partir do futuro $X$ inativo (Xi) e inicia a fase de silenciamento pelo seu acúmulo e posterior propagação (Clemson et al.,1996) (Figura 2). O estabelecimento do sinal de XIST depende de múltiplos fatores que regulam a sua expressão alelo-específica, tanto em cis quanto em trans. Dentre os fatores mais importantes nestas etapas iniciais estão as proteínas YY1 e CTCF, as quais atuam em trans e são importantes para a correta propagação do sinal de XIST ao longo do cromossomo X (Sun et al., 2013; Makhlouf et al., 2014). Alguns dos fatores mais destacados que atuam em cis são os ativadores RNF12 e hnRNPU, sendo que, o primeiro é importante nas fases iniciais da ICX, pois induz a expressão de XIST (Barakat et al., 2011) e o segundo é um regulador de splicing alternativo necessário para a produção da isoforma de XIST presente na ICX (Hasegawa et al., 2010).

Após estabelecido o sinal de XIST no futuro Xi, diferentes complexos modificadores de cromatina e proteínas que causam uma reorganização e compactação do cromossomo são recrutados. Dessa maneira, os principais eventos que levam ao estabelecimento da ICX são: a exclusão da RNA polimerase II dos domínios de ligação do RNA de XIST (Okamoto et al., 2004); a perda das marcas de cromatina ativa, como a metilação de histonas (H3K4, H3K9me2) (Kohlmaier et al., 2004) e hipoacetilação da H4 (Boggs et al., 1996); o ganho das marcas de cromatina inativa (H3K27me3, H3K9me3 e H4K20me1) (Plath et al., 2003; Silva et al., 2003), o recrutamento dos complexos repressivos polycomb 1 e 2 (PRC1 e PRC2) (Margueron, Reinberg, 2011) e a metilação das ilhas CpG do DNA (Lock et al., 1987; Gilbert, Sharp, 1999; Hellman et al., 2007) (revisto em Pinter, 2016). Após os complexos repressivos e metilação do DNA estabelecerem a compactação da heterocromatina, o Xi é replicado tardiamente e sofre compactação da cromatina até formar o que conhecemos como corpúsculo de Barr (Zhang et al., 2007). 
Além disso, sabe-se que em camundongos o gene Tsix (sobreposto no sentido antisense ao gene $X i s t$ ) é expresso no Xa (X ativo), evitando que o Xist seja expresso (Migeon et al., 2001). No entanto, em humanos, este é pouco conservado e não apresenta funções de repressão sobre o XIST, sendo possível que outros fatores exerçam esta função. Assim, em 2013, Vallot e colaboradores descreveram o IncRNA $X A C T$, o qual só é expresso no cromossomo Xa durante o estabelecimento da ICX. Contudo, a função deste ainda não é bem conhecida.

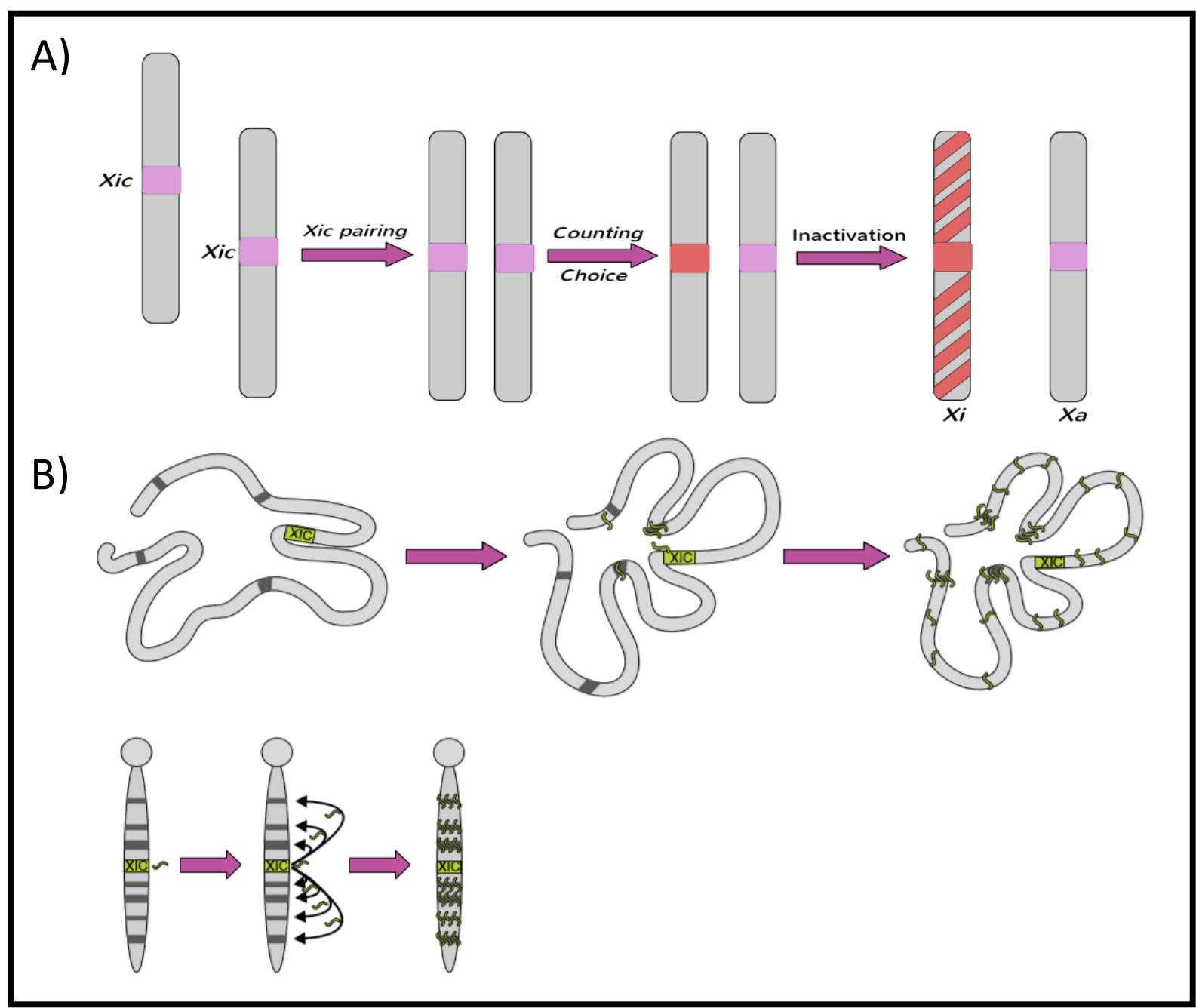

Figura 2 - Esquema representativo da regulação do processo de ICX - Iniciação. A) A iniciação da ICX começa com o pareamento dos cromossomos $X$ e posterior contagem do número destes em relação ao número de autossomos, por último, vem a escolha de qual cromossomo $X$ será inativado. Só um cromossomo $X$ permanece ativo por cada conjunto diplóide. B) O gene XIST que está localizado no XIC, produz um RNA longo não traduzido (IncRNA), que inicia a fase de silenciamento do futuro Xi, pelo seu acúmulo e posterior propagação ao longo do cromossomo. Fonte: Modificado de $\mathrm{Ng}$ et al., 2007.

\subsubsection{Manutencão}


A transição à fase de manutenção é marcada pelo surgimento de um Xi que apresenta uma localização periférica, com replicação tardia e um "locking" da sua memória epigenética através do recrutamento de fatores de repressão, os complexos PRC1/PRC2, a variante de histona macroH2A e a metilação das ilhas CpG no DNA. Durante a manutenção da ICX, a expressão do RNA XIST é dispensável, contudo, nos primeiros momentos desta fase o transcrito de XIST permanece associado ao Xi recrutando os diferentes fatores de heterocromatina (Figura 3) (revisto em Pinter, 2016).

A incorporação da proteína macroH2A marca a entrada da célula na fase de manutenção da ICX (Mermoud et al., 1999). Esta é considerada um repressor transcricional e geralmente é encontrada em co-localização com a marca de histona H3K27me3 na heterocromatina facultativa (Gamble et al., 2010). Estudos realizados com células-tronco embrionárias (ESC) já tem demonstrado que a macroH2A apresenta funções relacionadas à regulação da memória celular, pois atua como antagonista dos genes de pluripotência e regula a ativação dos genes necessários para a diferenciação celular (Creppe et al., 2012; Pasque et al., 2012). Atualmente, sabe-se que macroH2A é enriquecida ao longo do cromossomo Xi (Costanzi et al., 1998). Contudo, sua função durante a fase de manutenção ainda é pouco entendida e mais trabalhos deveram ser feitos ao respeito.

Segundo Chadwick e Willard (2004), dois diferentes tipos de heterocromatina são formados no Xi durante o processo de "locking" da memória do Xi. O primeiro tipo de heterocromatina, "Domínio 1", é enriquecido nas bandas G claras e é estruturalmente similar à heterocromatina facultativa. Esta é caracterizada pelo enriquecimento de H3K27me3, H2AK119ub, MacroH2A, e RNA XIST. O segundo tipo de heterocromatina, "Domínio 2", é enriquecido nas bandas G obscuras distribuídas ao longo do Xi e compartilha semelhanças com a heterocromatina pericêntrica, sendo enriquecida nas seguintes marcas: H3K9me3, H4K20me3 e HP1. Os detalhes de como estes diferentes domínios surgiram ainda não são claros, mas estes parecem formar um sistema de redundância parcial e reforço mútuo no processo de silenciamento do Xi (revisto em Dixon-Mcdougall, Brown, 2016). 
Outros fatores que são importantes para a manutenção da $\mathrm{XCl}$ são as proteínas SMCHD1 e HBiX1, as quais estão presentes nas regiões de divisa entre os dois tipos de heterocromatina do Xi; estas têm um papel mediador das interações entre os dois domínios de heterocromatina (revisto em Dixon-Mcdougall, Brown, 2016). Além disso, durante a manutenção da ICX, SMCHD1 apresenta um papel importante no estabelecimento do silenciamento gênico, pois este produz alterações na estrutura da cromatina que levam a compactação do Xi e a metilação do DNA nas regiões CpG (Blewitt et al., 2008). Em paralelo à metilação do DNA, a hipoacetilação das histonas H3 e H4 também asseguram que o Xi permaneça inativo e coordena a replicação sincrônica deste (Figura 3) (Casas-Delucchi et al., 2011; Csankovszki et al., 2001).

Uma das últimas marcas epigenéticas a ser estabelecida durante a ICX é a metilação do DNA, assim, acredita-se que esta tenha um papel mais importante na manutenção do que no estabelecimento do estado inativo do cromossomo $X$ (Yasukochi et al., 2010). Durante a fase de manutenção, o Xi apresenta um padrão de silenciamento onde a região promotora dos genes silenciados se encontra hipermetilada e o corpo dos genes hipometilado quando comparado ao Xa (Hellman, Chess 2007; Yasukochi et al., 2010). Em humanos, as DNA metiltransferases DNMT1, DNMT3A e DNMT3B são importantes para manter as marcas de metilação. A DNMT1 mantém as marcas de metilação durante a replicação do DNA, enquanto que, as outras DNMTs metilam sítios que escapam da metilação por DNMT1 (Vasques et al., 2005; revisto em Miller, Grant, 2012). Em camundongos, a deleção do gene Dnmt1 (DNA methyltransferase 1) produz uma reativação do cromossomo $\mathrm{Xi}$ (Sado et al., 2000) e a ausência de metilação na região promotora do Xist leva a uma inativação inapropriada do X (Panning, Jaenisch, 1996).

Por outro lado, diversos estudos têm demonstrado que alguns fatores que fazem parte da manutenção da XCI são dispensáveis. Em 2006, um estudo feito com camundongos transgênicos que sofreram depleção da EED (uma metiltransferase de histonas que faz parte do complexo PRC2) mostrou que estes não apresentaram alterações durante o processo da XCl (Kalantry, Magnuson, 2006). Outro estudo feito 
com células-tronco embrionárias de camundongo constatou que a $\mathrm{XCl}$ não era alterada em células deficientes em Ring1b, uma ligase do complexo PRC1 (Leeb, Wutz, 2007). Em 2004, Ohhata e colaboradores demonstraram que a G9a, uma metilase de H3K9me1 e H3K9me2, não é essencial para a inativação do X através do uso de embriões de camundongo (Ohhata et al., 2004). Ainda, Sado e colaboradores realizaram ensaios com camundongos transgênicos para demonstrar que as Dnmt3a/b, metiltransferases de novo, podem ser dispensáveis durante a XCl (Sado et al., 2004). Por fim, um estudo usando camundongos que sofreram knockdown da histona macroH2A demonstrou que esta é dispensável para a XCl (Perhson et al., 2014).

Nos últimos anos, só dois estudos descreveram fatores envolvidos na manutenção da ICX (Escamilla-Del-Arenal et al., 2013; Minkovsky et al., 2014). O primeiro é um estudo feito mediante o uso de células-tronco embrionárias de camundongo com mutação para as metiltransferases de histona. Este demonstrou que a CDYL é recrutada na cromatina inativa (Xi) pelas marcas de histona H3K9me2 e H3K27me3. Uma vez associada ao Xi, CDYL ajuda à propagação da marca de repressão H3K9me2 ao longo de todo o Xi (Escamilla-Del-Arenal et al., 2013). Já o segundo estudo, também feito em camundongos, revela que a proteína ATF7IP tem um papel importante na manutenção do estado de "bloqueio" do cromossomo X pósICX, pois esta interage com SETDB1 e MBD1 para coordenar a metilação da histona H3K9 e do DNA, respectivamente. Além disso, também demonstraram que esta interage com CDYL para coordenar a metilação da histona H3K9me2 (Minkovsky et al., 2014).

Em síntese, a manutenção da ICX é um processo mantido por uma série de fatores que atuam em sinergismo, tais como, hipermetilação da H3K27me3 e H3K9me3 (representantes dos dois domínios de heterocromatina no Xi), metilação do 
DNA nas ilhas de CpG, hipoacetilação das histonas H3 e H4 (Csankovszki et al., 2001; revisto em Minkovsky et al., 2014; Dixon-Mcdougall, Brown, 2016).

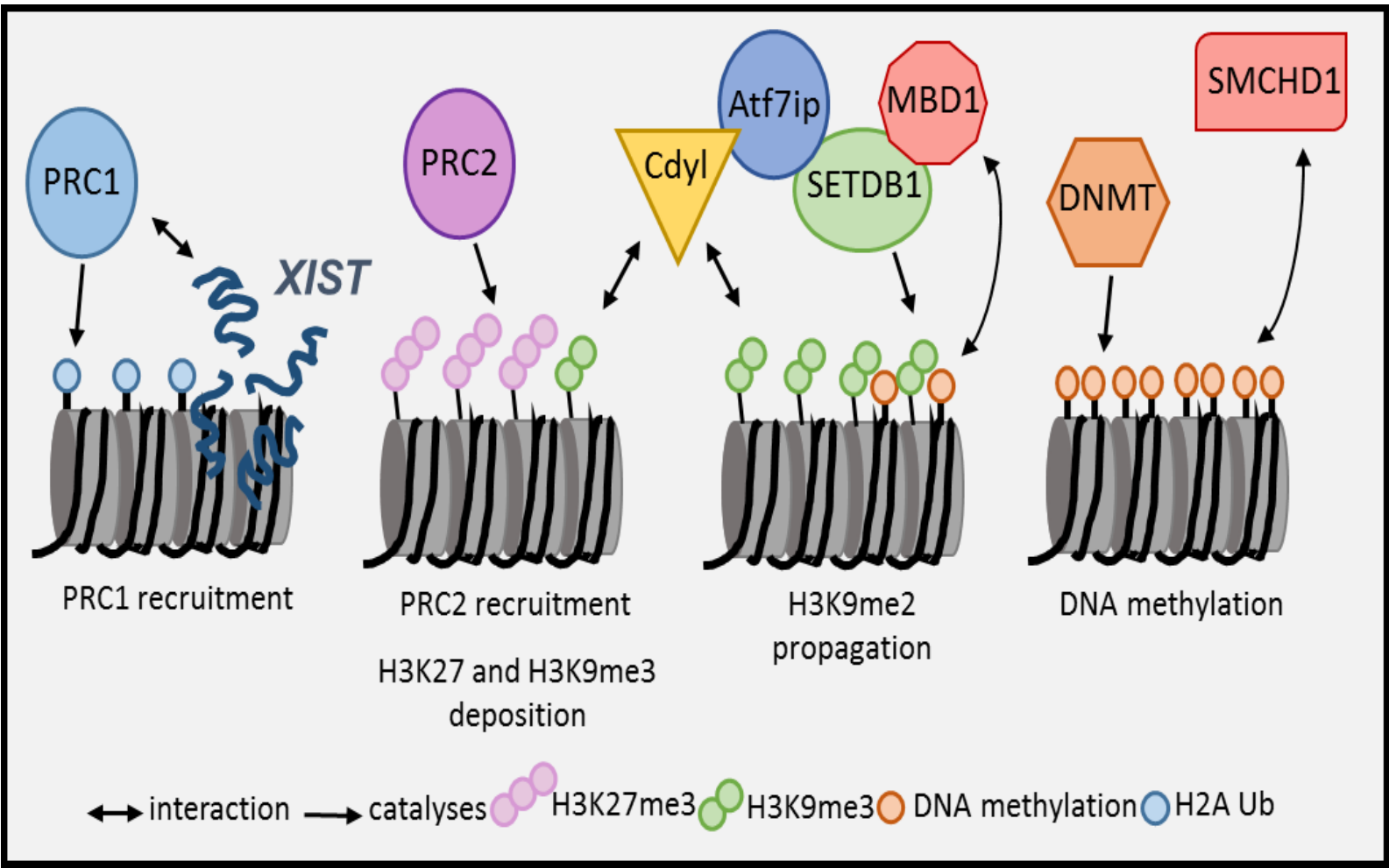

Figura 3 - Esquema representativo da regulação do processo de ICX - Manutenção. Durante a fase de manutenção o RNA XIST recruta complexos de silenciamento (PRC1 e PRC2) que atuam em sinergismo com marcas de cromatina inativa (H3K27me3 e H3K9me2) e as DNMTs para manter o estado inativo do X. Novos fatores como CDYL e ATF7IP tem sido propostos como proteínas importantes para manter o estado de silenciamento do Xi. Fonte: Modificado de Galupa e Heard, 2015.

\subsection{Triagens genômicas funcionais de genes envolvidos na ICX}

Nos últimos anos, múltiplos estudos com triagens funcionais em fibroblastos embrionários de camundongos têm sido realizados para desvendar outros possíveis fatores que apresentem um papel importante na ICX (Bhatnagar et al., 2014; Minkovsky et al., 2015; Chu et al., 2015; McHugh et al., 2015; Minajigi et al., 2015; Mondroit et al., 2015; Monfort et al., 2015). Contudo, o processo de ICX apresenta diferenças significantes entre camundongos e humanos, como o fato de XIST ser dispensável para a manutenção da ICX em humanos ou o número de genes que escapam à ICX em humanos ser maior que em camundongos (Chang, Brown, 2010). Além disso, a grande maioria de estudos se foca na descrição de fatores que atuam nas fases iniciais da ICX, deixando assim a identidade dos diferentes fatores 
envolvidos na manutenção da ICX pouco compreendidos.

No nosso laboratório, foi feita uma triagem funcional para poder identificar prováveis genes necessários para a manutenção do estado de inativação do cromossomo X (Vergani, 2014). Dessa maneira, foram utilizados como modelo celular fibroblastos dérmicos humanos 46, XX heterozigotos para uma mutação de perda de função no gene HPRT1, pois tem sido muito utilizados na literatura como ferramenta de detecção da reativação do cromossomo X (Mekhoubad et al., 2012). O gene HPRT1 codifica a enzima hipoxantina-guanina fosforibosiltransferase 1, que tem um papel importante na síntese de purinas pela via de recuperação de nucleotídeos, o que permite que as células possam ser facilmente selecionadas, de acordo com 0 alelo HPRT presente no $\mathrm{X}$ ativo, em meio contendo HAT (células HPRT+) ou 6TG (células HPRT-) (Watson et al., 1988).

Neste experimento, uma população de fibroblastos dérmicos humanos da linhagem GM1661 $\mathrm{HPRT}^{+/-}$foi selecionada positivamente para células HPRT- em meio 6TG, gerando uma população de células com o alelo normal do gene HPRT1 no X inativo (HPRT-) (Figura 4). Após transdução com uma biblioteca de shRNAs, estas foram divididas em dois grupos: um controle que foi mantido em meio 6TG para continuar a seleção positiva de células HPRT' e uma amostra experimental que foi colocada em meio HAT para a seleção positiva de células HPRT ${ }^{+}$. Dessa forma, se alguma célula sofresse o silenciamento de um gene importante para a manutenção do estado de inativação do cromossomo $X$, acarretaria a reativação do cromossomo Xi contendo o alelo $\mathrm{HPRT}^{+}$e estas sobreviveriam em meio HAT. Após tratamento com as drogas seletivas, foi realizado sequenciamento de próxima geração (NGS - Next Generation Sequencing) em cada uma das amostras para determinar a identidade dos shRNAs enriquecidos na amostra selecionada em HAT (Figura 4). Essas análises identificaram 20 possíveis candidatos à manutenção da $\mathrm{XCl}$ em humanos (Vergani, 2014). 


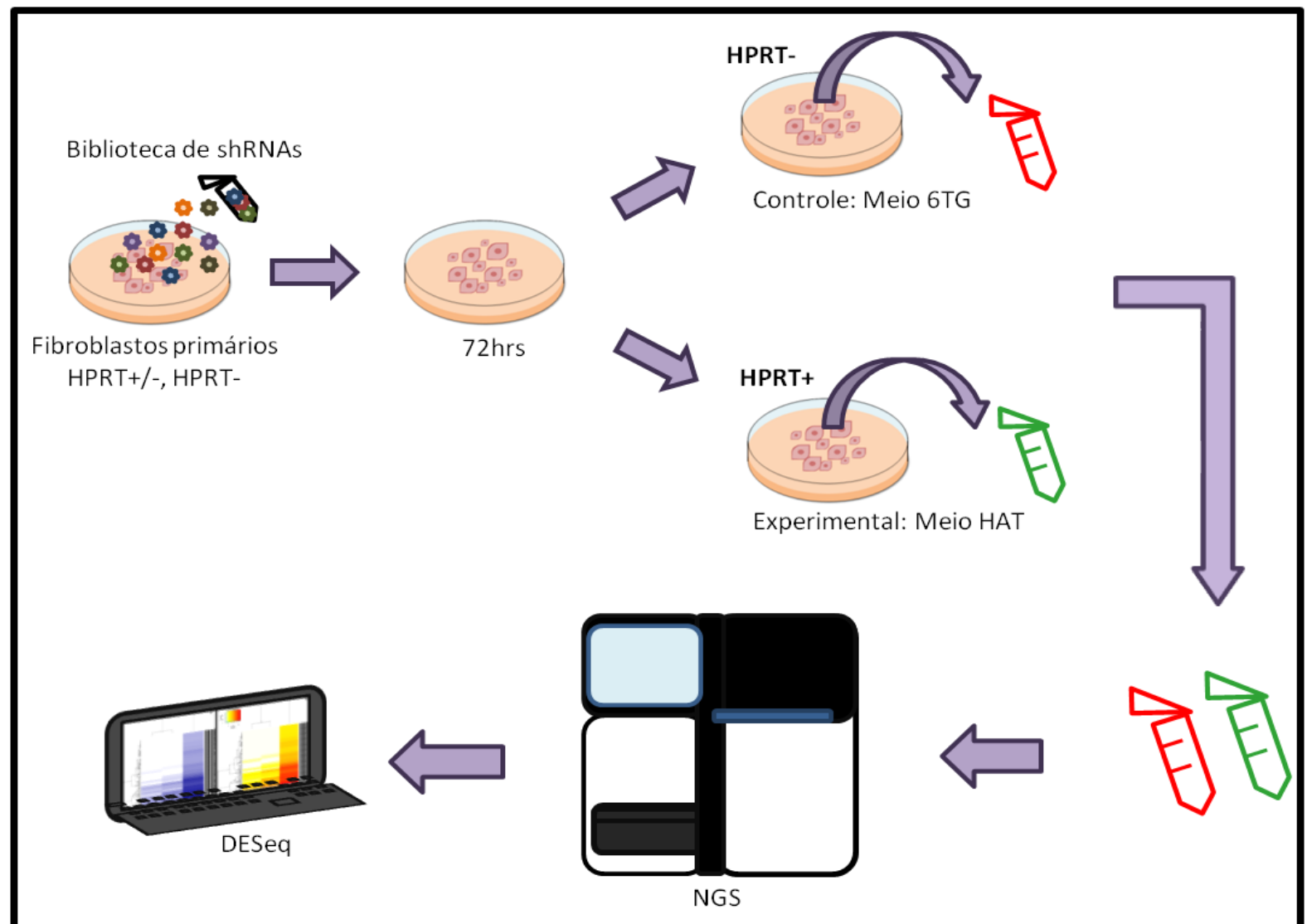

Figura 4 - Esquematização das etapas experimentais desenvolvidas durante a triagem funcional de genes envolvidos na manutenção da XCl em humanos. Fibroblastos primários 46, XX HPRT+/-, fenotipicamente HPRT-, foram transduzidos com uma biblioteca lentiviral de shRNAs. Após 72h, a população de células transduzidas foi dividida em duas populações: a amostra controle mantida em meio 6TG para seleção de células HPRT- e a amostra experimental mantida em HAT para seleção de células HPRT+ (células com reativação do Xi). O DNA genômico foi coletado e submetido ao sequenciamento de próxima geração (NGS) e análise computacional foi realizado para identificação e contagem de cada shRNA presente em cada amostra. Os dados obtidos foram comparados entre as amostras para determinação dos candidatos. Fonte: Modificado de Vergani, 2014.

\subsection{Genes candidatos}

O estudo da estrutura e função das proteínas codificadas por cada gene candidato pode fornecer pistas sobre um possível papel dos mesmos na manutenção da ICX ou em mecanismos de resistência ao tratamento com HAT. Dentre os 20 candidatos identificados na nossa triagem gênica, há 12 genes que foram considerados como os mais prováveis de apresentar um papel relacionado à manutenção da ICX. Este trabalho pretende analisar a função de dois deles $(H 3 F 3 B$, $A S F 1 A$ ), principalmente porque têm um papel em mecanismos de controle epigenético, o que Ihes outorga uma maior probabilidade de envolvimento na 
manutenção da ICX. Por exemplo, a proteína H3.3B (codificada pelo gene H3F3B, H3 histone family $3 B$ ) tem um papel no silenciamento gênico e está associada a sítios de início da transcrição de genes reprimidos (Goldberg et al., 2010). Além disso, esta proteína é encontrada em promotores silenciados bivalentes de células pluripotentes, os quais são caracterizados pelas modificações pós-transducionais H3K4me3 (geralmente associada a ativação da transcrição gênica) e H3K27me3 (geralmente associada a repressão da transcrição gênica) (Goldberg et al., 2010).

Já a proteína ASF1A (anti-silencing function 1A histone chaperone) é uma chaperona de histona que interage diretamente com H3 e H4 e está envolvida preferencialmente na montagem de nucleossomos e repressão da atividade gênica (Agez et al., 2007). ASF1A é a principal isoforma relacionada ao silenciamento gênico e quando complexada com HIRA (Histone Cell Cycle Regulator) e H3 forma SAHF (senescence-associated heterochromatic foci), regiões presentes em células senescentes ricas em MacroH2A e associadas ao silenciamento de genes envolvidos na proliferação celular (Banumathy et al., 2009). 


\section{OBJETIVOS}

\subsection{Objetivo geral}

O presente trabalho tem como principal objetivo validar dois genes candidatos a estarem envolvidos na manutenção da inativação do cromossomo $X$ em células somáticas femininas humanas.

\subsection{Objetivos específicos}

- $\quad$ Silenciar com shRNAs os 2 genes candidatos em células HPRT(+/-)/HPRT-:

- Transduzir células HPRT- usando lentivirus com código para shRNAs direcionados para o silenciamento dos dois genes candidatos selecionados, em ensaios independentes.

- Verificar se houve silenciamento de cada gene alvo no nível transcrional e traducional.

- Avaliar a reativação do Xi nas células transduzidas:

- Selecionar as células HPRT- transduzidas em meio HAT.

- Verificar se há expressão bi-alélica de genes originalmente submetidos à inativação do cromossomo X por SNPs informativos, previamente identificados em nosso laboratório.

- Avaliar a reativação do Xi através de RNA-FISH para o gene XIST e imunofluorescência para H3K27me3 e RNA Pol. II. 


\section{MATERIAL E MÉTODOS}

\subsection{Linhagens celulares}

Dois diferentes linhagens de fibroblastos dérmicos humanos primários foram usadas nesse trabalho; as linhagens GM1661 e GM1660, com cariótipo 46, XX, heterozigotas para uma mutação no gene HPRT1. Todas as linhagens acima mencionadas foram adquiridas do Centro de Pesquisa Coriell Institute for Medical Research $\circledast$. A linhagem derivada de rim de embrião humano e transformada para expressar o antígeno T denominada HEK293T foi adquirida do centro de pesquisa ATCC®.

\subsection{Procedimentos gerais de cultivo celular}

\subsubsection{Cultivo de células}

As linhagens de fibroblastos e a HEK293T foram cultivadas a $37 \stackrel{\circ}{\mathrm{C}} \mathrm{com} 5 \%$ $\mathrm{CO}_{2}$ em placas aderentes. A formulação dos meios de cultura utilizados foi baseada nos protocolos previamente padronizados no nosso laboratório e nas recomendações dadas pelas empresas fornecedoras. Para a manutenção das células foi usado meio de fibroblastos denominado GM contendo $20 \%$ de soro fetal bovino (FBS) com a seguinte formulação:

- 1 X DMEM High Glucose (Life Technologies ${ }^{\mathrm{TM}}$ - Gibco®, Cat\#11965-092)

- 20\% FBS-ES Cell-Qualified (Life Technologies ${ }^{\mathrm{TM}}$ - Gibco®, Cat\# 10439024)

- 0.1 mM MEM NEAA (Life Technologies ${ }^{\mathrm{TM}}$ - Gibco®, Cat\# 11140-050)

- 1 mM Sodium Piruvate (Life Technologies ${ }^{\mathrm{TM}}$ - Gibco®, Cat\# 11360-070)

- 2 mM GlutaMAX ${ }^{\mathrm{TM}}$ Supplement (Life Technologies ${ }^{\mathrm{TM}}$ - Gibco®, Cat\# 35050061)

- $100 \mathrm{U} / \mathrm{mL}$ Penicillin / $100 \mu \mathrm{g} / \mathrm{mL}$ Streptomycin (Life Technologies ${ }^{\mathrm{TM}}$ - 
Gibco®, Cat\# 15140-122)

\subsubsection{Passagem das células}

A metodologia de passagem das linhagens celulares empregada consistiu de 5 etapas. O meio de cultura foi removido das placas e as células lavadas com DPBS (Life Technologies ${ }^{\mathrm{TM}}$ - Gibco®, Cat\# 14190-144) (Etapa 1). Em seguida, foi adicionada a solução de tripsina-EDTA 0,25\% (Life Technologies ${ }^{\mathrm{TM}}$ - Gibco®, Cat\#25200-072) e incubada a $37 \stackrel{\circ}{\circ} \mathrm{C}, 5 \% \mathrm{CO}_{2}$ por 3 minutos (Etapa 2). Para parar a reação de tripsinização, foi adicionado meio de cultura GM pré-aquecido em banho-maria a 37 ${ }^{\circ} \mathrm{C}$ (Etapa 3). Depois, as células em suspensão foram transferidas para um tubo falcon de $15 \mathrm{~mL}$ e centrifugadas a $200 \mathrm{~g}$ por 5 minutos a RT (Etapa 4). Finalmente, o sobrenadante foi descartado, o pellet ressuspendido em volume de meio GM apropriado, transferido para placas de cultura e as mesmas foram incubadas a $37^{\circ} \mathrm{C}$, $5 \% \mathrm{CO}_{2}$ (Etapa 5).

\subsubsection{Congelamento de células}

As diferentes linhagens utilizadas nesse trabalho foram congeladas seguindose o protocolo padrão adotado em nosso laboratório. O protocolo constou de 6 etapas. Etapa 1: O meio de cultura foi removido das placas e as células lavadas com DPBS. Etapa 2: Em seguida, foi adicionada a solução de tripsina-EDTA 0,25\% e incubada a $37 \stackrel{\circ}{\circ}, 5 \% \mathrm{CO}_{2}$ por 3 minutos. Etapa 3: Para parar a reação de tripsinização, foi adicionado meio de cultura GM pré-aquecido em banho-maria a $37{ }^{\circ} \mathrm{C}$. Etapa 4: Depois, as células em suspensão foram transferias para um tubo falcon de $15 \mathrm{~mL}$ e centrifugadas a $200 \mathrm{~g}$ por 5 minutos a temperatura ambiente. Etapa 5: $\mathrm{O}$ sobrenadante foi descartado e o pellet ressuspendido em meio de congelamento de fibroblastos (90\% FBS-ES Cell-Qualified e 10\% DMSO - Sigma-Aldrich ${ }^{\circledR}$, Cat\# D2650). Etapa 6: Finalmente, as células ressuspendidas foram transferidas para um criotubo, colocadas em recipiente criogênico (Mr. Frosty Freezing Container, ThermoScientific ${ }^{\mathrm{TM}}$ - Nalgene ${ }^{\circledR}$, Cat\# $5100-001$ ), transferidas para freezer $-80^{\circ} \mathrm{C}$ por 24 horas e posteriormente colocadas em nitrogênio líquido. 


\subsubsection{Descongelamento de células}

As diferentes linhagens utilizadas nesse trabalho foram descongeladas segundo o protocolo padrão utilizado em nosso laboratório, descrito a seguir. Etapa 1: O criotubo contendo as células foi transferido para o banho-maria a $37 \stackrel{\circ}{\mathrm{C}}$ por um minuto para que ocorra o descongelamento. Etapa 2: Em seguida, a amostra foi transferida para um tubo falcon de $15 \mathrm{~mL}$ e foram adicionados $5 \mathrm{~mL}$ de meio de cultura GM ao tubo falcon. Etapa 3: A amostra foi centrifugada a $200 \mathrm{~g}$ por $5 \mathrm{~min}$ a temperatura ambiente. Etapa 4: O pellet foi ressuspendido em volume apropriado de meio GM, transferido para placa de cultura apropriada e colocada na incubadora a 37 ${ }^{\circ} \mathrm{C}, 5 \% \mathrm{CO}_{2}$. Etapa 5: Após 24 horas, o meio de cultura foi trocado e a placa retornada novamente à incubadora a $37 \stackrel{\circ}{\circ} \mathrm{C}, 5 \% \mathrm{CO}_{2}$.

\subsection{Seleção de células HPRT- na linhagem GM1661}

Para seleção das células HPRT-, utilizamos as células da linhagem GM1661 heterozigotas para o gene HPRT (HPRT+/-). Inicialmente cultivamos essas células em meio básico para cultivo denominado GM (descrito no item 3.2.1) para expansão. Uma vez expandidas, estas foram passadas por tripsinização na proporção 1:3 em garrafas T25 com o seguinte propósito:

- Garrafa 1: Controle não-tratado (também para geração de estoque congelado)

- Garrafa 2: Tratamento com meio HAT: seleção de células HPRT+

- Garrafa 3: Tratamento com meio contendo 6TG: seleção de células HPRT-

Para seleção positiva das células HPRT- e eliminação das células HPRT+, as células foram mantidas em meio GM contendo $60 \mu \mathrm{M}$ Hybri-Max ${ }^{\mathrm{TM}}$ 6-Thioguanine (Sigma-Aldrich $\AA$, Cat\# A-4660) por quatro semanas, enquanto que, para seleção das células HPRT+, as células foram cultivadas em meio GM suplementado com 1,5 X HAT ( $5 \mathrm{mM}$ hipoxantina de sódio, $20 \mu \mathrm{M}$ de aminopterina e $0.8 \mathrm{mM}$ de timidina) (Life 
Technologies $^{\mathrm{TM}}$ - Gibco®, Cat\# 21060-017). Durante o tratamento das células nos meios enriquecidos com HAT e 6TG a troca dos mesmos foi realizada a cada dois dias.

\subsection{Transdução das linhagens celulares GM1661 e HEK293T com shRNAs}

As partículas lentivirais para os genes $H 3 F 3 B$ e $A S F 1 A$ foram obtidas da empresa Sigma-Aldrich (MISSION® shRNA Lentiviral Transduction Particles, human) (Tabela 1). O experimento de transdução foi realizado com base nas instruções fornecidas pelo fabricante. O protocolo utilizado constou de cinco etapas. Etapa 1: Foram plaqueadas $30 \times 10^{3}$ células/poço em 10 poços de uma placa de 24wells; Etapa 2: 24 horas depois do plaqueamento, as células foram lavadas com DPBS e em seguida foi adicionado uma mistura de solução lentiviral para uma MOI de 5 em 400 $\mu \mathrm{L}$ de meio GM com 2\% FBS-ES Cell-Qualified e $1 \times$ TransDux $^{\mathrm{TM}}$ (System Biosciences, Cat\# LV850A-1); Etapa 3: 24 horas após transdução, o meio das células foi trocado para o meio GM com 20\% FBS- ES Cell-Qualified; Etapa 4: 48 horas após transdução, as células foram passadas com meio GM para uma placa de 12 poços; Etapa 5: 24 horas após a passagem, iniciou-se o tratamento com puromicina (PuromycinDihydrochloride, Life Technologies - Thermo Fisher Scientific, Cat\# A1113803) (400 ng / mL) em meio GM, para seleção das células transduzidas. A troca do meio foi realizada a cada dois dias durante oito dias. 
Tabela 1 - Genes silenciados neste estudo. Todos os vetores foram obtidos da empresa Sigma Aldrich.

\begin{tabular}{|c|c|c|l|}
\hline Gene & Código da Empresa & shRNA No & Sequência-alvo \\
\hline \multirow{4}{*}{ ASF1A } & NM_014034.1-341s1c1 & 1 & CCGGGTGAAGAATACGATCAAGTTTCTCGAGAAACTTGATCGTATTCTTCACTTTTTG \\
\cline { 2 - 5 } & NM_014034.1-462s1c1 & 2 & CCGGAGGCGTAACTGTTGTGCTAATCTCGAGATTAGCACAACAGTTACGCCTTTTTTG \\
\cline { 2 - 5 } & NM_014034.1-424s1c1 & 3 & CCGGGCACCTAATCCAGGACTCATTCTCGAGAATGAGTCCTGGATTAGGTGCTTTTTG \\
\hline \multirow{3}{*}{ H3F3B } & NM_005324.3-809s21c1 & 1 & CCGGGACTTGTTGGGTAGCTATTAACTCGAGTTAATAGCTACCCAACAAGTCTTTTTG \\
\cline { 2 - 5 } & NM_005324.3-436s21c1 & 2 & CCGGGGTGGGTCTGTTCGAAGATACCTCGAGGTATCTTCGAACAGACCCACCTTTTTG \\
\cline { 2 - 5 } & NM_005324.3-277s1c1 & 3 & CCGGGCTTCGAGAGATTCGTCGTTACTCGAGTAACGACGAATCTCTCGAAGCTTTTTG \\
\hline
\end{tabular}




\subsection{Seleção de células HPRT+ em fibroblastos primários humanos transduzidos}

Para seleção das células HPRT+, foram usadas as células transduzidas e as células não transduzidas. Primeiramente, as células foram expandidas para discos de $60 \mathrm{~mm}$ em meio GM. Uma vez atingida uma confluência de $90 \%$, estas foram passadas por tripsinização na proporção $1: 2 \mathrm{em}$ discos de $60 \mathrm{~mm}$ com o seguinte propósito:

- Disco 1: Controle 1: células HPRT- sem transdução de shRNA, cultivadas em meio GM.

- Disco 2: Controle 2: células HPRT- transduzidas com shRNA, cultivadas em meio GM.

- Disco 3: Controle 3: células HPRT- sem transdução de shRNA, cultivadas em meio HAT.

- Disco 4: análise de reativação: células HPRT- transduzidas com shRNA, cultivadas em meio HAT.

O tratamento seletivo em meio GM suplementado com 1,5 x HAT e meio GM foi realizado trocando-se o meio dos discos de cultura a cada dois dias e durou 12 dias.

\subsection{Extração de RNA}

Para a extração de RNA, as células foram coletadas em $1 \mathrm{~mL}$ de Trizol (Thermo Fisher Scientific, Cat\#15596026), adicionou-se $200 \mu \mathrm{l}$ de clorofórmio (Merck Millipore, Cat\#1024451000) e agitou-se vigorosamente. Após ter centrifugado a $12000 \mathrm{~g}$ por um período de 15 minutos a $4^{\circ} \mathrm{C}$, foi coletado o sobrenadante destas e transferido para novo tubo. Em seguida, foi adicionado um volume de isopropanol (Merck Millipore, Cat\# 1009931000) em cada tubo e misturou-se por inversão. Após deixar no gelo por 15 minutos e nova centrifugação a $12000 \mathrm{~g}$ por um período de 10 minutos a $4{ }^{\circ} \mathrm{C}$, o sobrenadante foi descartado e adicionou-se $700 \mu \mathrm{l}$ de etanol $70 \%$ ao pellet, misturou- 
se por inversão e centrifugou-se a $12.000 \mathrm{~g}$ por 5 minutos a $4{ }^{\circ} \mathrm{C}$. Finalmente, o sobrenadante foi passado pela coluna do Kit RNeasy (Qiagen, Cat\# 74106) e tratado com DNAse I para remoção de DNA total (RNase-Free DNase Set, Quiagen, Cat\# 79254) seguindo as instruções do fabricante. As amostras foram ressuspendidas em $50 \mu \mathrm{l}$ de água DEPC, quantificadas no espectrofotômetro ND1000 (NanoDrop®, Thermo Fisher Scientific Inc., USA) e guardadas a $-80^{\circ} \mathrm{C}$. Adicionalmente, para avaliar a integridade do RNA, analisaram-se $0.25 \mu \mathrm{g}$ de RNA total em gel de agarose $1 \%$.

\subsection{Síntese de cDNA}

O cDNA de cada amostra foi sintetizado a partir de $1 \mu \mathrm{g}$ de RNA previamente tratado com DNase. Para isto, utilizou-se o High-Capacity cDNA Reverse Transcription Kit (AppliedBiosystems, Cat \# 4368814) de acordo com as instruções fornecidas pelo fabricante. Para verificar se as amostras de RNA apresentavam alguma contaminação com DNA genômico, foi gerada uma alíquota da amostra onde a transcriptase reversa não era adicionada (RT-). Em seguida, para verificar a qualidade dos cDNAs, foi realizada uma PCR para o gene de controle endógeno $\beta$ actina (F: 5'- CCAGCTCACCATGGATGATG - 3' e R: 5'- ATGCCGGAGCCGTTGTC3'). Para cada reação foi usado $200 \mathrm{nM}$ de cada primer, 1 x de solução de tampão de reação, $50 \mathrm{mM}$ de $\mathrm{MgCl}_{2}, 5 \mathrm{mM}$ de dNTPs (Invitrogen - Thermo Fisher Scientific, Cat\#10297018), 50 ng de cDNA e 1 U de Taq DNA polimerase (Taq DNA Polymerase recombinant - Thermo Fisher Scientific, Cat\#10342020), em volume final de $20 \mu \mathrm{l}$. As condições de amplificação foram: Etapa 1 ( 1 ciclo) $-94{ }^{\circ} \mathrm{C} \times 5$ minutos; etapa 2 (35 ciclos) $-94^{\circ} \mathrm{C} \times 30$ segundos; $58^{\circ} \mathrm{C} \times 30$ segundos; $72{ }^{\circ} \mathrm{C} \times 45$ segundos. Após 0 termino da etapa de amplificação, as amostras foram avaliadas por corrida eletroforética em gel de agarose $3 \%$.

\subsection{RT-PCR em tempo real}

Para a amplificação de cDNA por qPCR, utilizaram-se sondas TaqMan® Gene Expression Assay (Thermo Fisher Scientific) desenhadas especificamente para cada gene a ser investigado e para o IncRNA de XIST (Tabela 2). Foi usado o 
StepOnePlus ${ }^{\mathrm{TM}}$ System (AppliedBiosystems, Thermo Fisher Scientific Inc., Califórnia, EUA). Para cada amostra, foi preparado um pré-mix de reação onde foram utilizados 7,5 $\mu$ l de TaqMan® Universal PCR Master Mix 2x (Thermo Fisher Scientific, Cat\# 4304437), 0,75 $\mu \mathrm{l}$ de Taqman array 20x (primer) (Thermo Fisher Scientific) e 5,75 $\mu \mathrm{l}$ de água DEPC. Separadamente, numa placa de 96 poços foi adicionado $14 \mu \mathrm{l}$ de solução de pré-mix por amostra. Após a adição do pré-mix nos poços das amostras, $1 \mu \mathrm{l}$ de cDNA (50 $\mathrm{ng} / \mu \mathrm{l}$ ) foi adicionado separadamente em cada poço. Antes de colocar a placa no equipamento, esta foi selada com filme e centrifugada a $800 \mathrm{rpm}$ por 1 minuto. Cada amostra foi realizada em triplicata e cada sonda Taqman utilizada teve um controle negativo. Como controle endógeno foi utilizada uma sonda para o gene da $\beta$-actina. As condições de amplificação foram: Etapa 1 ( 1 ciclo) $-50{ }^{\circ} \mathrm{C} \times 2$ minutos; etapa 2 ( 1 ciclo) $-95^{\circ} \mathrm{C} \times 10$ minutos; etapa 3 (40 ciclos) $-95{ }^{\circ} \mathrm{C} \times 15$ segundos; $60{ }^{\circ} \mathrm{C} \times 1$ minuto. Para análise dos dados obtidos, seguiram-se as indicações de Pfaffl (2001). Todas as figuras foram plotadas usando o programa GraphPad Prism 6.0 software (Califórnia, EUA).

Tabela 2 - Lista de sondas Taqman utilizadas para técnica de RT-PCR em tempo real. Todas as sondas foram obtidos da empresa Thermo Fisher Scientific.

\begin{tabular}{|c|c|c|}
\hline Gene & $\begin{array}{c}\text { Código da } \\
\text { Empresa }\end{array}$ & Fluoróforo \\
\hline$A C T B$ & Hs01060665_g1 & VIC \\
\hline$A S F 1 A$ & Hs00204044_m1 & FAM \\
\hline H3F3B & Hs00287906_s1 & FAM \\
\hline$X I S T$ & Hs01079824_m1 & FAM \\
\hline
\end{tabular}

\subsection{PCR para amplificação do gene HPRT1}

Para confirmar que a expressão alelo-específica das células transduzidas sofreu uma mudança e que tínhamos reativado o Xi, foi desenhada uma PCR para amplificação do cDNA do gene HPRT1. O desenho dos oligonucleotídeos foi baseado nas sequências dadas por Yang e colaboradores (1988). Estes amplificam dois diferentes tamanhos de fragmentos, um de $363 \mathrm{pb}$ para o alelo selvagem e um de 653 
pb para o alelo mutado. A seguir a sequência dos oligonucleotídeos $\left(\operatorname{Tm} 62^{\circ} \mathrm{C}\right)$ :

Foward: 5'- CCGTTATGGCGACCCGCAGCCCTGG- 3'

Reverse: 5'- CTCCACCAATTACTTTTATGTCCCC- 3'

As PCRs foram montadas adicionando-se $1 \mu \mathrm{l}$ de cada oligonucleotídeo (concentração final de $500 \mathrm{nM}$ ), $2 \mu \mathrm{l}$ de solução tampão $10 \times, 0,6 \mu \mathrm{l}$ de $50 \mathrm{mM} \mathrm{MgCl}$, $0,4 \mu \mathrm{l}$ de dNTPs a $10 \mathrm{mM}, 0,4 \mu \mathrm{l}$ da enzima Phire Hot Start II DNA polimerase (Thermo Fisher Scientific, Cat\# F122S), $1 \mu$ do cDNA e água deionizada para um volume final de $20 \mu \mathrm{l}$ para cada reação. As condições de amplificação foram: Etapa 1 (1 ciclo) - 98 ${ }^{\circ} \mathrm{C} \times 30$ segundos; etapa 2 (40 ciclos) $-98^{\circ} \mathrm{C} \times 15$ segundos; $62{ }^{\circ} \mathrm{C} \times 20$ segundos; $72{ }^{\circ} \mathrm{C} \times 30$ segundos; etapa 3 ( 1 ciclo) $-72{ }^{\circ} \mathrm{C} \times 4$ minutos. Após o termino da etapa de amplificação, as amostras foram avaliadas por corrida eletroforética em gel de agarose $3 \%$.

\subsection{Imunofluorescência}

\subsubsection{Marcas de Inativacão}

Para o estudo in situ das marcas de inativação do cromossomo $\mathrm{X}$, analisamos a marca de histona inativa H3K27me3 e RNA Pol II por imunofluorescência. Tanto as células GM1661 desviadas, como as células GM1661 transduzidas com o shH3F3B.2 e as células GM1661 transduzidas com o shH3F3B.2 e selecionadas em HAT foram plaqueadas em lamínulas numa confluência de $50 \%$. Após 48 horas de cultivo, estas foram lavadas duas vezes com PBS e fixadas por 40 minutos em formaldeído $2 \%$ em PBS. Após fixação, as lamínulas contendo as células foram transferidas para outra placa e lavadas três vezes com PBS por 3 minutos cada. Em seguida, para permeabilização do núcleo, colocou-se $1 \mathrm{~mL}$ de Triton $0,05 \%$ e incubou-se a temperatura ambiente por 10 minutos. Após três lavagens em PBS (Life Technologies - Gibco, Cat\# 10010-023), as células foram incubadas durante uma hora com BSA 2\% em PBS. Depois, incubou-se por 16 horas a $4{ }^{\circ} \mathrm{C}$ com o anticorpo primário diluído apropriadamente em BSA $2 \%$. Após três lavagens com PBS por 5 minutos cada, as lamínulas foram incubadas durante uma hora com o anticorpo secundário (conjugado) em diluição apropriada em tampão de bloqueio. Como anticorpos primários utilizamos 
os anticorpos anti-H3K27me3 (1:100) (Millipore, Cat\# 07-449) e anti-RNApol.II (1:100) (Millipore, Cat\# 05-623). Como anticorpos secundários utilizamos os anticorpos Alexa Fluor® 488 Goat Anti-Rabbit IgG (1:1000) (Thermo Fisher Scientific - Invitrogen, Cat\# R37116) e Alexa Fluor® 594 Goat anti-Rabbit lgG (1:1000) (Thermo Fisher Scientific - Invitrogen, Cat\# R37117). Por último, as laminas foram montadas com Vecta-shield Mounting Medium (Vector Laboratório, Cat\# H1200) contendo DAPI (marcador nuclear), as imagens foram capturadas com microscópio Confocal Zeiss LSM 880 (Carl Zeiss Inc., Jena, Alemanha) e analisadas no programa ZEN (Black Edition) (Carl Zeiss Inc., Jena, Alemanha).

\subsubsection{Proteína $\mathrm{H} 3.3$}

Para análise da proteína H3.3, tanto as células GM1661 desviadas (utilizadas como controle positivo) quanto as células transduzidas com o shH3F3B.2 foram plaqueadas em lamínulas numa confluência de 50\%. Após 48 horas de cultivo, estas foram lavadas duas vezes com PBS e fixadas por 5 minutos em metanol 100\% (Merck, Cat\# 1060091000). Após fixação, as lamínulas contendo as células foram transferidas para outra placa e lavadas três vezes com PBS por 3 minutos cada. Em seguida, para permeabilização do núcleo, colocou-se $1 \mathrm{~mL}$ de solução de permeabilização (BSA 1\%, $0.3 \mathrm{M}$ glicina, 0,1\% Tween e PBS) e deixou-se a temperatura ambiente por 1 hora. Após três lavagens em PBS, incubou-se por 16 horas a $4{ }^{\circ} \mathrm{C}$ com o anticorpo primário diluído apropriadamente em BSA 2\%. Após três lavagens com PBS por 5 minutos cada, as lamínulas foram incubadas durante uma hora com o anticorpo secundário (conjugado) em diluição apropriada em tampão de bloqueio. Como anticorpo primário foi utilizado o anticorpo anti-H3.3 (1:100) (Abcam Cat\# ab97968). Como anticorpo secundário utilizou-se o anticorpo Alexa Fluor® 488 Goat Anti-Rabbit IgG (1:1000) (Thermo Fisher Scientific - Invitrogen, Cat\# R37116). Por último, as laminas foram montadas com Vecta-shield Mounting Medium (Vector Laboratório, Cat\# H1200) contendo DAPI (marcador nuclear), as imagens foram capturadas com microscópio Confocal Zeiss LSM 880 (Carl Zeiss Inc., Jena, Alemanha) e analisadas no programa ZEN (Black Edition) (Carl Zeiss Inc., Jena, Alemanha). 


\subsection{FISH de RNA}

Este ensaio foi realizado tanto com as células GM1661 (GM1661 desviada, GM1661 desviada e transduzida com o shH3F3B.2 e GM1661 desviada, transduzida com o shH3F3B.2 e tratada com HAT), quanto as células HEK293T (utilizadas como controle positivo). As células foram plaqueadas em lamínulas numa confluência de $50 \%$. Após 48 horas de cultivo, foram lavadas duas vezes com PBS e fixadas por 20 minutos em paraformaldeído 4\% (Sigma Aldrich, Cat\# P6148) diluído em PBS. Após fixação de 24 horas em álcool 70\%, as lamínulas contendo as células foram passadas para outra placa e lavadas com tampão de lavagem ( 2 x SSC, 10\% formamida, $\mathrm{H}_{2} \mathrm{O}$ deionizada). Em seguida, incubadas overnight a $37^{\circ} \mathrm{C}$ com uma sonda para o RNA XIST (1:50) (Stellaris, Cat\# SMF-1025-5) em câmara úmida. Após lavagem de uma hora a $37^{\circ} \mathrm{C}$ com tampão de lavagem montaram-se as laminas com Vecta-shield Mounting Medium (Vector Laboratório) contendo DAPI e as imagens foram capturadas com microscópio Confocal Zeiss LSM 880 (Carl Zeiss Inc., Jena, Alemanha) e analisadas no programa ZEN (Black Edition) (Carl Zeiss Inc., Jena, Alemanha).

\subsection{Digital droplet PCR (ddPCR)}

Para investigar a expressão alelo-específica de genes do cromossomo $\mathrm{X}$, utilizou-se um SNP da região codificadora de um gene previamente identificado como heterozigoto para a linhagem GM1661 em trabalho realizado em nosso laboratório: ATRX (rs3088074). Para cada amostra realizou-se uma extração de RNA e síntese de cDNA como o descrito nos tópicos 3.6 e 3.7 respectivamente, seguido da técnica de ddPCR. Primeiramente foram desenhados primers para amplificação da região de interesse e sondas para detecção do alelo referência e do alelo variante do SNP rs3088074 (Tabela 2). Para a quantificação das amostras por ddPCR usou-se o QX200 Droplet Digital PCR system (Bio-Rad Laboratories, Inc., Pleasanton, CA) e o protocolo utilizado constou de quatro etapas. Etapa1: Foi preparado um mix de PCR onde colocamos $10 \mu \mathrm{L}$ de 2 x ddPCR Master Mix (Bio-Rad, Cat\# 186-3010), 0,95 $\mu \mathrm{L}$ de cada primer (concentração final de $900 \mathrm{nM}$ ), 1,05 $\mu \mathrm{L}$ de sonda (concentração final de $250 \mathrm{nM}$ ), 3,05 $\mu \mathrm{L}$ de água milliQ e 4,5 $\mu \mathrm{L}$ de cDNA para cada amostra. Etapa2: De 
cada poço com amostra foram transferidos $20 \mu \mathrm{L}$ do mix de PCR para o cartucho formador de gotículas (Bio-Rad, Cat\# 1864008); depois, $70 \mu \mathrm{L}$ do óleo gerador de gotículas (Bio-Rad, Cat\#186-3030) foram colocados nos poços para óleo. Em seguida, o cartucho foi vedado com uma borracha (Bio-Rad, Cat\# 1863009) e colocado no QX200 droplet generator (Bio-Rad, Cat\# 1864002). Etapa3: A emulsão de gotículas gerada foi transferida para uma placa de PCR de 96-well (Eppendorf, Cat\# 0030601106), selada com uma PX1 PCR plate sealer (Bio-Rad, Cat\# 181-4000) e sujeita a amplificação no termociclador C1000 Touch thermalcycler (Bio-Rad, Cat\# 185-1197). Para a amplificação da PCR foi usado o seguinte programa: 10 minutos a $95{ }^{\circ} \mathrm{C}$; 15 segundos a $95{ }^{\circ} \mathrm{C}$ e 60 segundos a $55^{\circ} \mathrm{C}$ (40 ciclos com uma rampa de temperatura de $2.5^{\circ} \mathrm{C} / \mathrm{s}$ ) e 10 minutos a $98^{\circ} \mathrm{C}$. Etapa4: Após concluída a PCR, transferimos a placa para o QX200 droplet reader (Bio-Rad, Cat\# 1864003) para captura da fluorescência de cada gota em cada poço e posterior analise. A distinção entre gotas positivas e negativas foi feita baseada num valor limite determinado previamente (3000 copias/ amostra). Só foram consideradas positivas as amostras que tinham pelo menos 3 gotas.

Tabela 3 - Lista dos primers e sondas utilizadas para técnica de digital droplet PCR

\begin{tabular}{|l|l|}
\hline \multicolumn{1}{|c|}{ Nome } & \multicolumn{1}{c|}{ Sequencia } \\
\hline Primer Forward & GATCGACTTCCTAAGAAGCAGCAAG \\
\hline Primer Reverse & GTTTTGGTTTTGAGATGCTTGCTC \\
\hline Sonda REF & CTGGGAAAGAGGAGAG \\
\hline Sonda VAR & CTGGGAAAGAGCAGAG \\
\hline
\end{tabular}

\subsection{RNA-Seq}

Para poder identificar mudanças no padrão de expressão alelo-específica das nossas amostras foi isolado o RNA total das amostras de células GM1661 desviadas e transduzidas com o TRC2-GFP (shScrable) (S3), células GM1661 desviadas e transduzidas com o shH3F3B.2 e selecionadas em meio HAT (S2) como descrito no item 3.5. Para o experimento de RNA-Seq, as amostras mencionadas foram 
nomeadas da seguinte maneira: S2 - células transduzidas com shRNA contra o gene candidato e selecionadas com HAT e S3 - células transduzidas com scramble.

As bibliotecas de mRNA foram preparadas de acordo com o protocolo Illumina TruSeq Stranded mRNA Sample Prep LS (Illumina, Califórnia, EUA) e o sequenciamento de última geração de RNA total (RNA-Seq) foi feito em uma HiSeq 2500 FlowCell v4, com o Kit HiSeq SBS v4 (Illumina, Cat\# FC-401-4002) e leituras pareadas de 125 bp ( $2 \mathrm{x}$ ) pelo Departamento de Genética da ESALQ/USP. Os dados brutos foram filtrados com o programa Trimmomatic (Bolger et al., 2014). As reads que passaram no controle de qualidade foram então alinhadas contra a sequência de referência humana (Hg19) usando o software livre TopHat v2.1.0 (Kim et al., 2013). Só foram consideradas as reads que apresentaram um alinhamento único no genoma e no máximo 3 mismatches.

\subsubsection{Expressão alelo-especifica}

Para poder detectar possíveis polimorfismos nas nossas amostras utilizamos os programas SAMTools e VarScan (Koboldt et al., 2009, 2012). Para avaliação da expressão alelo-específica, foi necessária a utilização de um banco personalizado de SNPs previamente construído no nosso laboratório pela doutora Joana Carvalho Moreira de Mello (Moreira de Mello, 2015). A seleção de SNPs que tiveram uma mudança de padrão de expressão foi feita utilizando os parâmetros previamente descritos por Borensztein (Borensztein et al., 2017), onde a contagem direta das reads de cobertura de cada SNP é feita baseando-se nas anotações de SNPs em regiões transcritas para depois calcular a razão relativa de expressão entre os alelos nas amostras da linhagem GM1661. Apenas foram considerados bialélicos os genes que se encontravam entre os limiares 0,85 e 0,15, como descrito por Borensztein (Borensztein et al., 2017) e apresentaram um mínimo de 8 reads de cobertura. Como controle de padrão de expressão bialélico foram utilizados os polimorfismos presentes nos genes autossômicos. Todas as figuras foram plotadas usando $R$ (version 2.15.2) software. Todas as análises foram feitas pela doutora Joana Carvalho Moreira de Mello. 


\subsubsection{Expressão gênica}

Para avaliar se existe uma diferença de expressão entre os genes das amostras, foi aplicado um teste-t univariado com uma janela móvel de 50 genes consecutivos, baseados nos dados de TPM (transcritos por milhão), para cada amostra. Para todos os testes foi utilizado um valor $p$ menor ou igual a 0,05 . Todas as figuras foram plotadas usando $R$ (version 2.15.2) software. Todas as análises foram feitas pelo doutor Gustavo Ribeiro Fernandes. 


\section{RESULTADOS}

\subsection{ASF1A}

\subsubsection{Validacão de shRNAs na linhagem HEK293T}

A linhagem HEK293T foi utilizada como modelo para seleção dos shRNAs mais eficientes para cada gene candidato, pois esta linhagem já havia demonstrado anteriormente ser uma linhagem altamente susceptível à transdução pelas partículas lentivirais (Naldini et al., 1996; Poeschla et al., 1998; Shalem et al., 2014).

Após transdução dos lentivirus contendo os diferentes shRNAs e cultivo em meio de seleção com o antibiótico puromicina, as células foram expandidas para a obtenção de amostras de RNA e realização de qPCR para verificação de silenciamento gênico. A Figura 5 mostra o gráfico com as quantificações de expressão de $A S F 1 A$ nas células transduzidas com os diferentes shRNAs, sendo que, a melhor eficiência de silenciamento foi vista com o shASF1A.3, contudo este mostrava uma baixa eficiência de transdução (dados não mostrados). Dessa maneira, foi decidido usar o shASF1A.1 nos testes da linhagem GM1661.

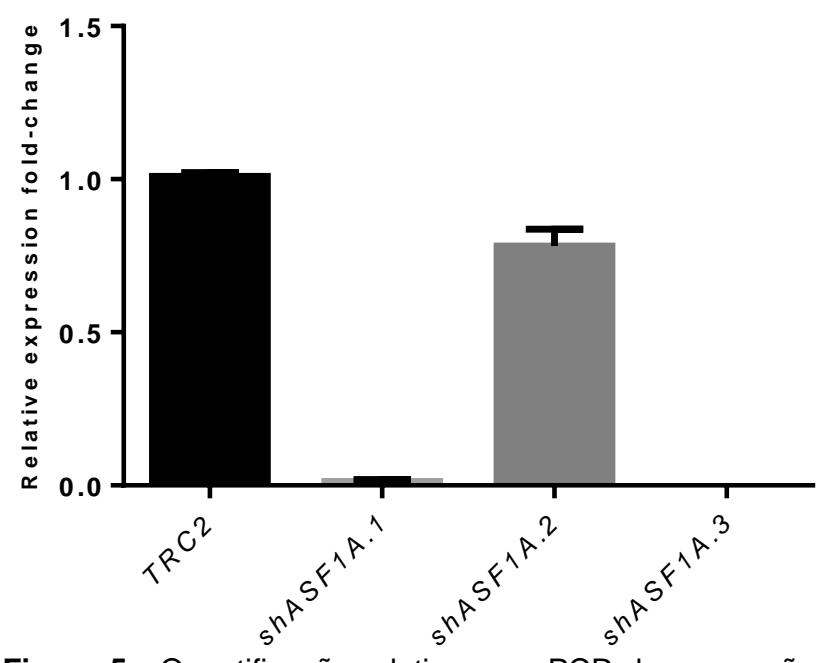

Figura 5 - Quantificação relativa por qPCR da expressão de ASF1A em células HEK293T transduzidas com lentivirus para produção de diferentes shRNAs, utilizando o gene ACTB como normalizador e a amostra "TRC2" como calibradora/referência. Os ensaios foram feitos em triplicata. 


\subsubsection{Validacão de shRNAs escolhidos na linhagem GM1661 desviada}

Uma vez que já tínhamos selecionado o shRNA com a melhor taxa de silenciamento procedemos a realizar o experimento de transdução das células GM1661 HPRT- seguindo o protocolo descrito no item 3.4. Os resultados da qPCR mostraram uma diminuição da expressão de $A S F 1 A$ de aproximadamente $80 \%$ (Figura 6).

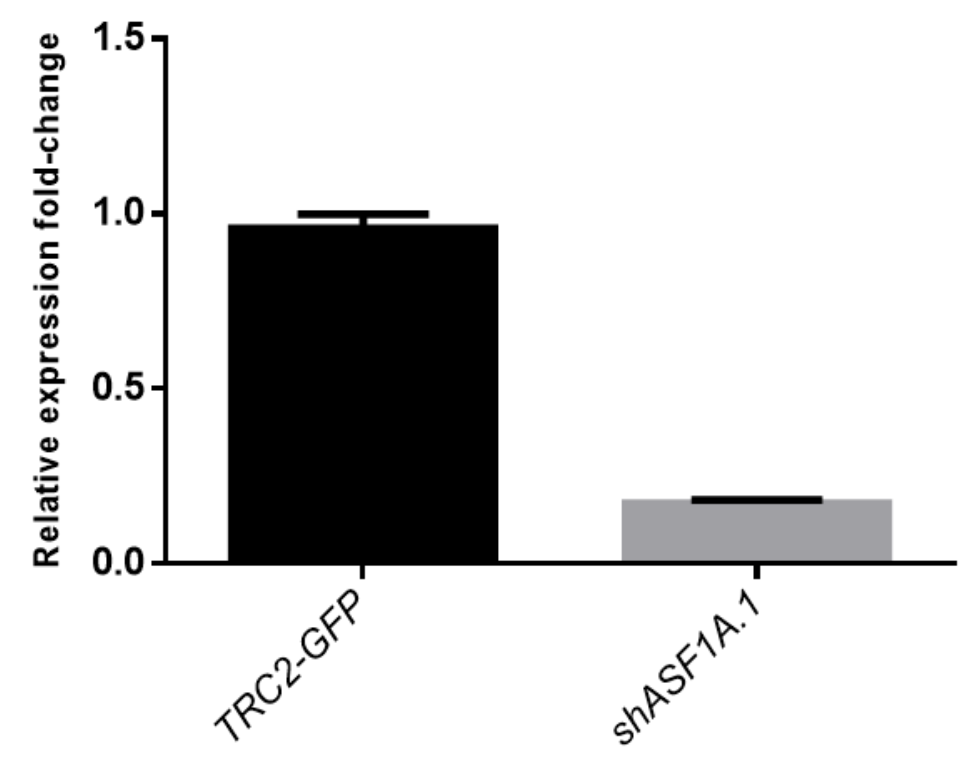

Figura 6 - Quantificação relativa por qPCR da expressão de $A S F 1 A$ em células GM1661 transduzidas com lentivirus para produção de shRNAs, utilizando o gene ACTB como normalizador e a amostra "TRC2-GFP" como calibradora/referência. Os ensaios foram feitos em triplicatas experimentais.

\subsubsection{Selecão de fibroblastos humanos primários HPRT+}

Visto que a linhagem usada nos experimentos era uma GM1661 desviada para a expressão do alelo HPRT-, se algum dos nossos genes candidatos apresentasse algum papel na manutenção da inativação do $X$, a ausência deste provocaria a reativação do cromossomo Xi e, em consequência, a expressão do alelo $H P R T^{+}$. Assim, para seleção das células reativadas, as células transduzidas foram cultivadas em meio com HAT 1,5x como descrito no item 3.5. Ao cultivar as células transduzidas com o shASF1A.1, observamos que, tanto as células transduzidas com os shRNAs quanto as células controle (células transduzidas com TRC2-GFP) morreram, restando 
aproximadamente $20 \%$ de células na placa após os 12 dias de cultivo (Figura 7 ).

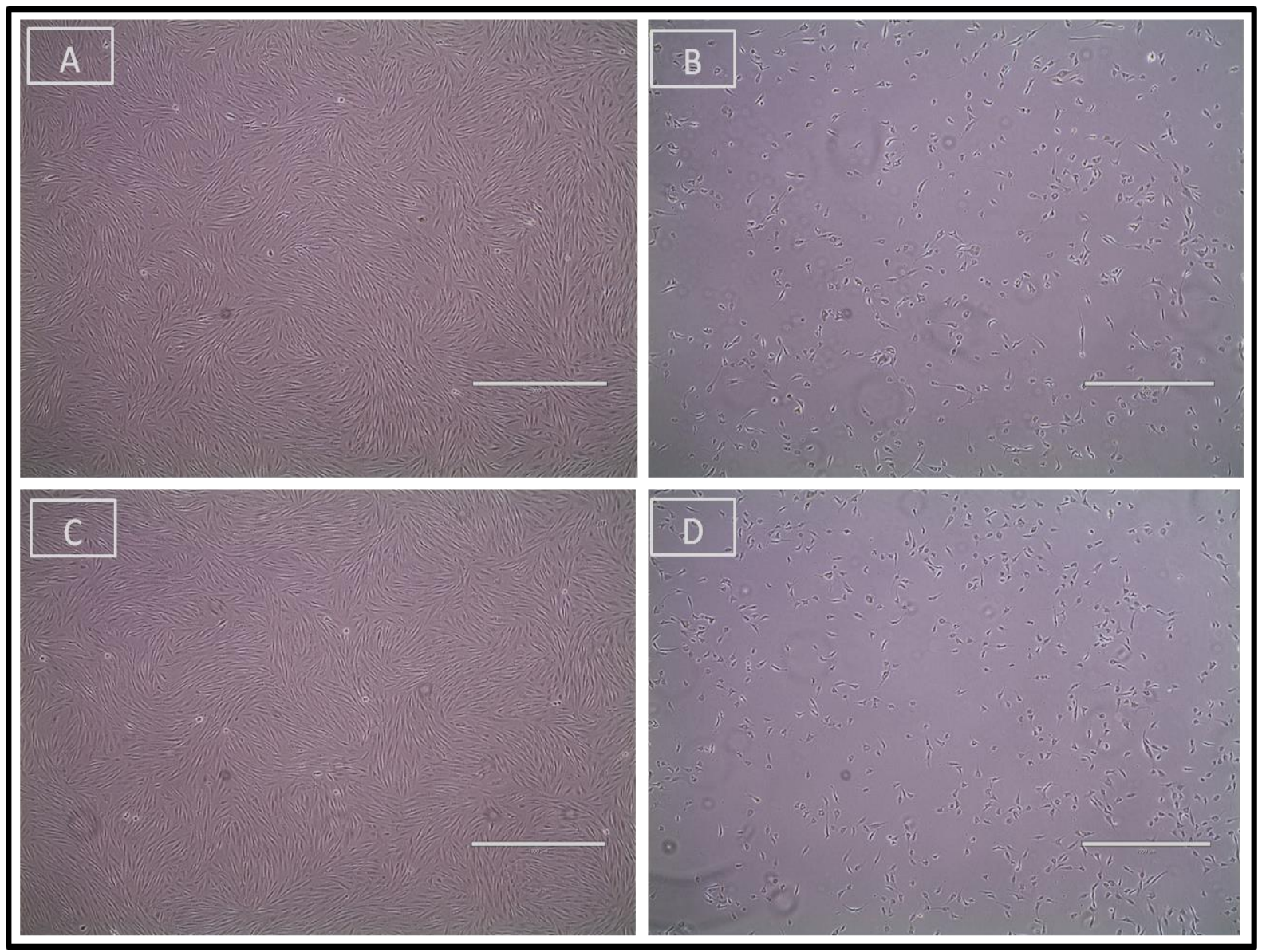

Figura 7- Células transduzidas com o shASF1A.1 no décimo segundo dia de cultivo em HAT 1,5 x. A) shASF1A.1 em meio GM; B) shASF1A.1 em meio HAT 1,5 x; C) Controle em meio GM (células transduzidas com TRC2-GFP); D) Controle em meio HAT 1,5 x (células transduzidas com TRC2-GFP). Aumento de $4 \mathrm{x}$.

\subsection{H3F3B}

\subsubsection{Validacão de shRNAs na linhagem HEK293T}

Nas células HEK293T transduzidas com diferentes shRNAs para H3F3B, a análise por qPCR mostrou que as células transduzidas com o shH3F3B.1 e shH3F3B.2 produziam uma diminuição parecida da expressão do transcrito de $H 3 F 3 B$ (Figura 8 ), $60 \%$ e $50 \%$ respectivamente. Assim, foi decidido continuar os testes de transdução na linhagem GM1661 com ambos os shRNAs. 


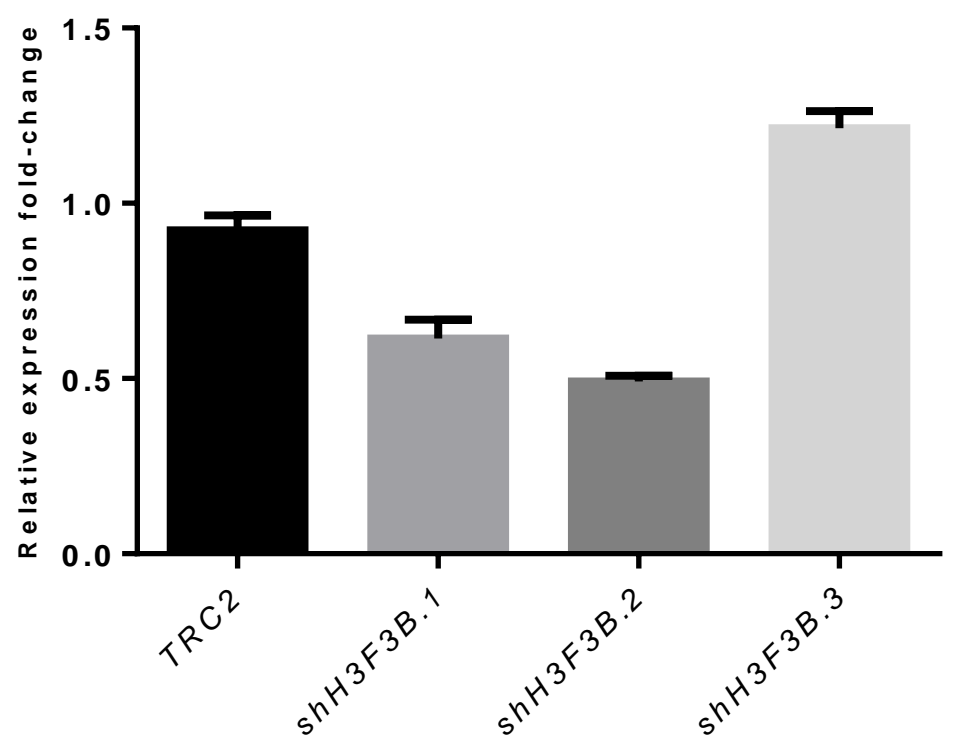

Figura 8 - Quantificação relativa por qPCR da expressão de $H 3 F 3 B$ em células HEK293T transduzidas com lentivirus para produção de diferentes shRNAs, utilizando o gene ACTB como normalizador e a amostra "TRC2" como calibradora/referência.

\subsubsection{Validacão de shRNAs escolhidos na linhagem GM1661 desviada}

Para investigarmos os níveis do transcrito do H3F3B nas células GM1661 avaliamos a sua expressão por qPCR. A Figura 9 mostra o gráfico de quantificação de expressão de H3F3B em células GM1661 transduzidas com dois diferentes shRNAs. Assim, foi possível observar que enquanto o shH3F3B.1 produzia uma diminuição do transcrito de $H 3 F 3 B$ de aproximadamente $60 \%$, o shH3F3B.2 produzia uma diminuição de aproximadamente 50\%. 


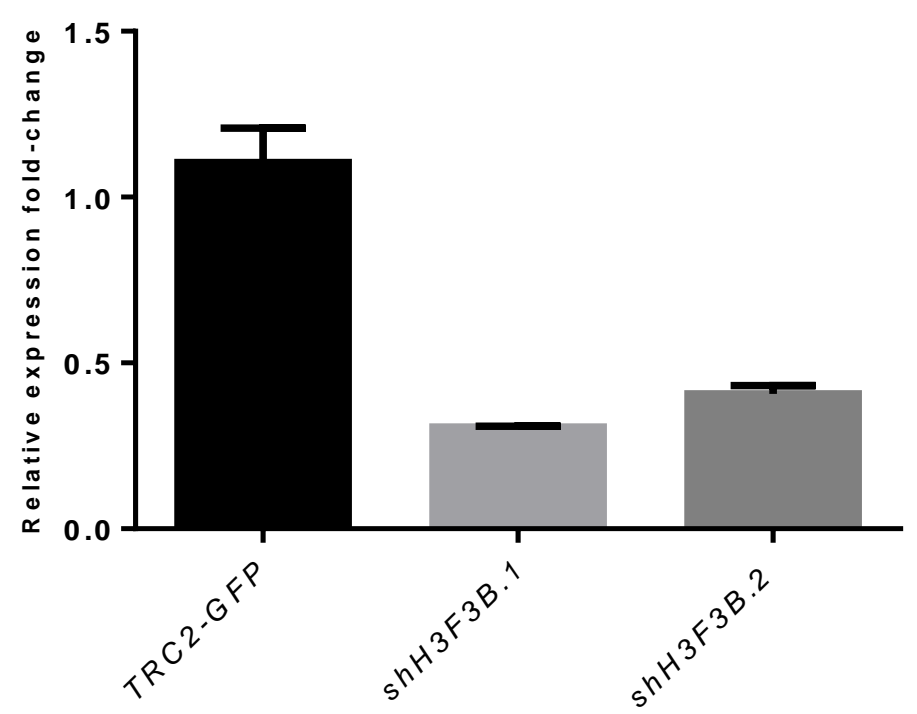

Figura 9 - Quantificação relativa por qPCR da expressão de H3F3B em células GM1661 transduzidas com lentivirus para produção de dois diferentes shRNAs, utilizando o gene $A C T B$ como normalizador e a amostra "TRC2-GFP" como calibradora/referência. Os ensaios foram feitos em triplicata técnica.

\subsubsection{Selecão de fibroblastos humanos primários HPRT+}

Uma vez determinado o shRNA que apresentava melhor eficiência de transdução e taxa de silenciamento do gene candidato, partimos para avaliar possível reativação do cromossomo Xi através de seleção das células transduzidas em meio HAT. Para isso, as células da linhagem GM1661 transduzidas com o shH3F3B.2 foram cultivadas em meio HAT 1,5x por 12 dias. Assim, no decimo terceiro dia pudemos observar que as células transduzidas e cultivadas em meio HAT sobreviveram à seleção, crescendo até atingir uma confluência de $80 \%$, sugerindo que ao menos em parte houve reativação do Xi (Figura 10B), enquanto que, as células controle (células transduzidas com TRC2-GFP) cultivadas em meio de seleção morreram, restando aproximadamente $20 \%$ de células na placa (Figura 10D). Para as células transduzidas com o shH3F3B. 1 não foi possível fazer os testes de seleção de fibroblastos humanos primários HPRT+, pois a taxa de eficiência de transdução destas foi muito baixa (dados não mostrados). 


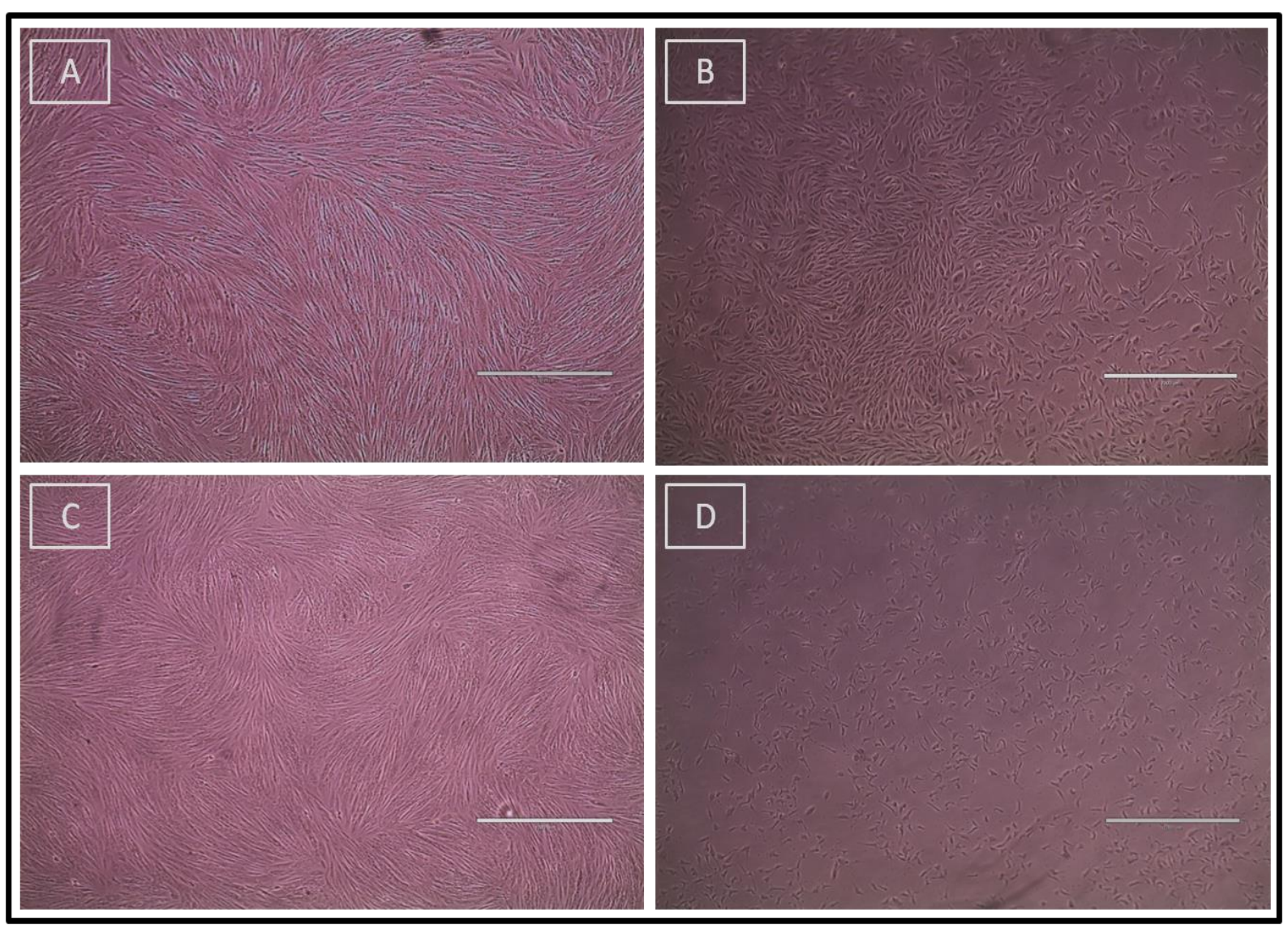

Figura 10 - Células transduzidas com o shH3F3B.2 no décimo segundo dia de cultivo em HAT 1,5 x. A) shH3F3B.2 em meio GM; B) shH3F3B.2 em meio HAT 1,5 x; C) Controle em meio GM (células transduzidas com TRC2-GFP); D) Controle em meio HAT 1,5 x (células transduzidas com TRC2-GFP). Aumento de $4 \mathrm{x}$.

\subsubsection{Análise da expressão da proteína $H 3.3$}

Para verificar que o silenciamento gênico de $H 3 F 3 B$ também tinha um efeito a nível transducional, ou seja, diminuição na produção da proteína H3.3, realizamos ensaios de imunofluorescência como descrito no item 3.11.2. Mediante uma dupla marcação para H3.3 (em verde) e DAPI (em azul) foi possível verificar que as células que foram transduzidas com o shH3F3B.2 apresentavam uma redução da proteína H3.3 em relação às células usadas como controle (Figura 11). Células da linhagem GM1661 desviadas foram usadas como controle, pois as células GM1661 transduzidas com o scramble continham GFP (células transduzidas com TRC2-GFP). Por outro lado, também foi tentado demostrar esta diminuição de proteínas através de ensaios de western blot (dados não mostrados), contudo a técnica apresentou algumas dificuldades que serão discutidas mais adiante. 


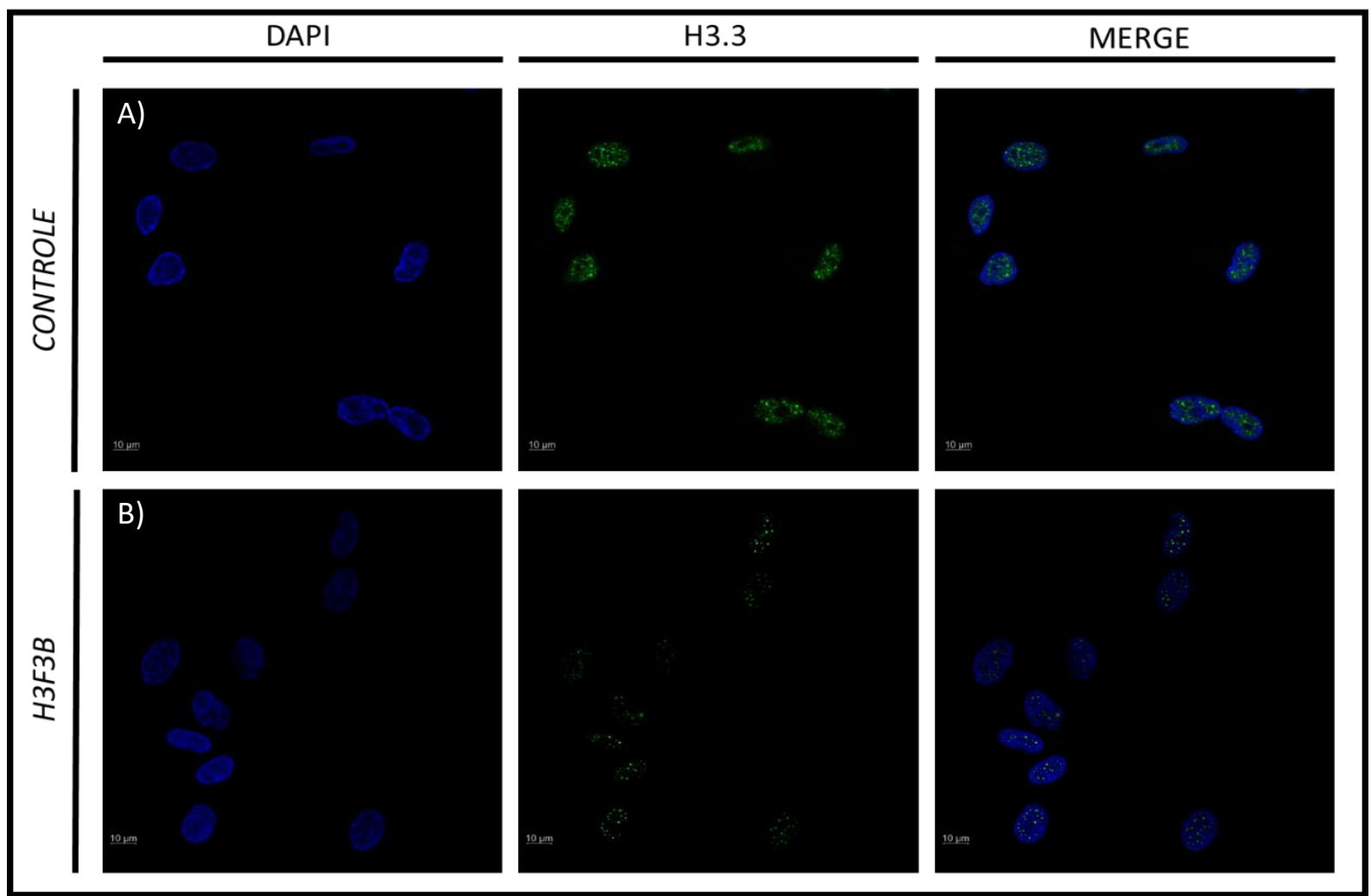

Figura 11 - Avaliação da expressão de H3.3 por Imunofluorescência. A) Células GM1661 desviadas marcadas para H3.3; B) Células GM1661 transduzidas com o shH3F3B.2 marcadas para H3.3. Em verde marcação para H3.3 e em azul marcação com DAPI. Aumento 20 x.

\subsubsection{Análise da reativacão do Xi}

\subsubsection{Análise das marcas de cromatina inativa}

Durante a ICX, o transcrito de RNA XIST cobre o Xi e em paralelo há também uma exclusão da maquinaria de transcrição dos territórios do Xi (exclusão da RNA Pol II) e um acúmulo da marca de histona inativa H3K27me3 (Chaumeil et al., 2006; Plath et al., 2003). Dessa maneira, caso as células transduzidas apresentassem uma reativação do $\mathrm{Xi}$, estas apresentariam uma perda das marcas de cromatina inativa (perda de H3K27me3 e RNA XIST, presença de RNA Pol. II). As marcas in situ de inativação foram analisadas por imunocitoquímica com os anticorpos anti- H3K27me3, anti-RNAPol II e RNA-FISH com a sonda anti-XIST segundo os protocolos descritos nos itens 3.11.1 e 3.12, respectivamente. Mediante uma dupla marcação para H3K27me3 (em verde) e RNA Pol II (em vermelho) foi possível determinar que nas células da linhagem GM1661 transduzidas com o shH3F3B.2 não havia perda das 
marcas de repressão. Todos os 60 núcleos contados apresentaram o acúmulo de histona H3K27me3 e ausência da RNA Pol Il dos domínios do Xi. O mesmo resultado foi obtido para os 60 núcleos analisados, oriundos das células transduzidas com o shH3F3B.2 selecionadas em meio HAT (Figura 12).

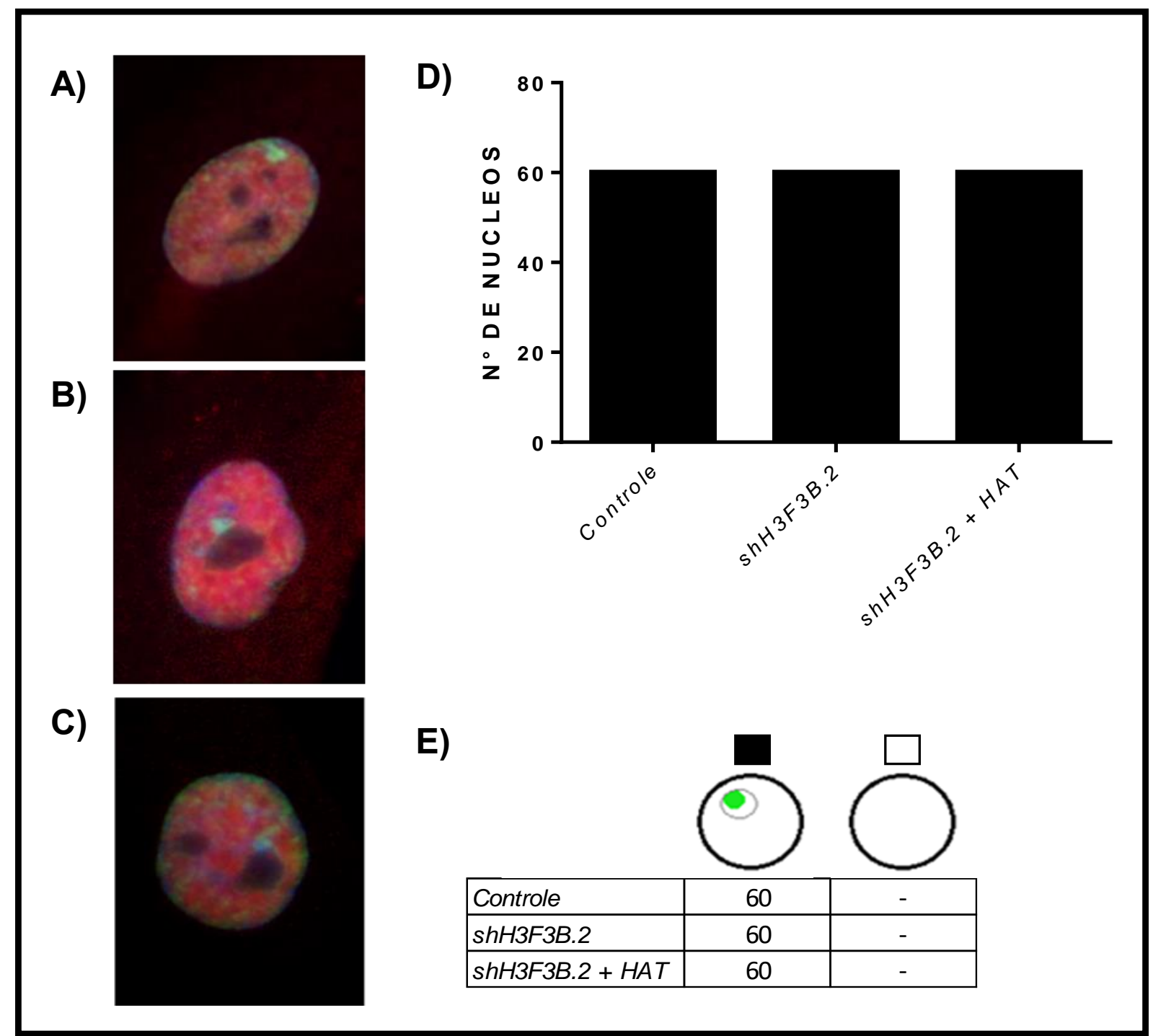

Figura 12 - Avaliação do acúmulo da H3K27me3 e exclusão da RNA Pol. II. A) Células GM1661 marcadas com os anticorpos H3K27me3 e RNA Pol. II; B) Células GM1661 transduzidas com o shH3F3B.2 marcadas para H3K27me3 e RNA Pol. II; C) Células GM1661 transduzidas com o shH3F3B.2 e selecionadas em HAT marcadas para H3K27me3 e RNA Pol. II; D) Histograma de número de núcleos positivos para marcação da H3K27me3 e RNA Pol II; E) Esquema mostrando a relação entre marcas de H3K27me3 com RNA Pol II e número de núcleos analisados. Em vermelho, marcação para RNA Pol II, em verde marcação para H3K27me3 e em azul marcação com DAPI. Aumento 40x.

Para avaliação da nuvem de XIST que é transcrita a partir do Xi, foram realizados ensaios de RNA-FISH e qPCR como descritos nos itens 3.12 e 3.8 respectivamente. Os ensaios de RNA-FISH foram realizados nas células GM1661 
desviadas, nas células GM1661 desviadas e transduzidas com o shH3F3B.2 e nas células GM1661 desviadas, transduzidas com o shH3F3B.2 e selecionadas em HAT. No primeiro teste de RNA-FISH (Figura 13) as células foram utilizadas nas passagens 29, 30 e 31 respectivamente. Todos os 50 núcleos da linhagem GM1661, acima mencionada, foram analisados e apresentaram marcação para a nuvem de XIST (em verde) (Figura 13B, 13C e 13D). Nesse experimento foi utilizada a linhagem HEK293T como controle positivo (Figura 13A), a qual apresenta aneuploidias no número de cromossomos X. No segundo teste de RNA-FISH (Figura 14) as células foram utilizadas em passagens maiores (29-35). Nestas, observamos que os núcleos contados nas células GM1661 desviadas e as células GM1661 desviadas e transduzidas com o shH3F3B.2 todos apresentavam sinal de XIST (Figura 14.1B, 14.1C), mas os núcleos contados nas células GM1661 desviadas, transduzidas com o shH3F3B.2 e selecionadas em HAT apresentavam uma população variada. Algumas células apresentaram sinal (12 núcleos) (Figura 14.1D), enquanto outras não apresentaram sinal (8 núcleos) (Figura 14.1E). Em total, foram contados 20 núcleos nas amostras de células GM1661 desviadas, células GM1661 desviadas e transduzidas com o shH3F3B.2 e células GM1661 desviadas, transduzidas com o shH3F3B.2 e selecionadas em HAT (Figura 14.2 e 14.3). Como controle negativo foram utilizadas células GM1661 sem marcação com a sonda XIST (Figura14.1A). 


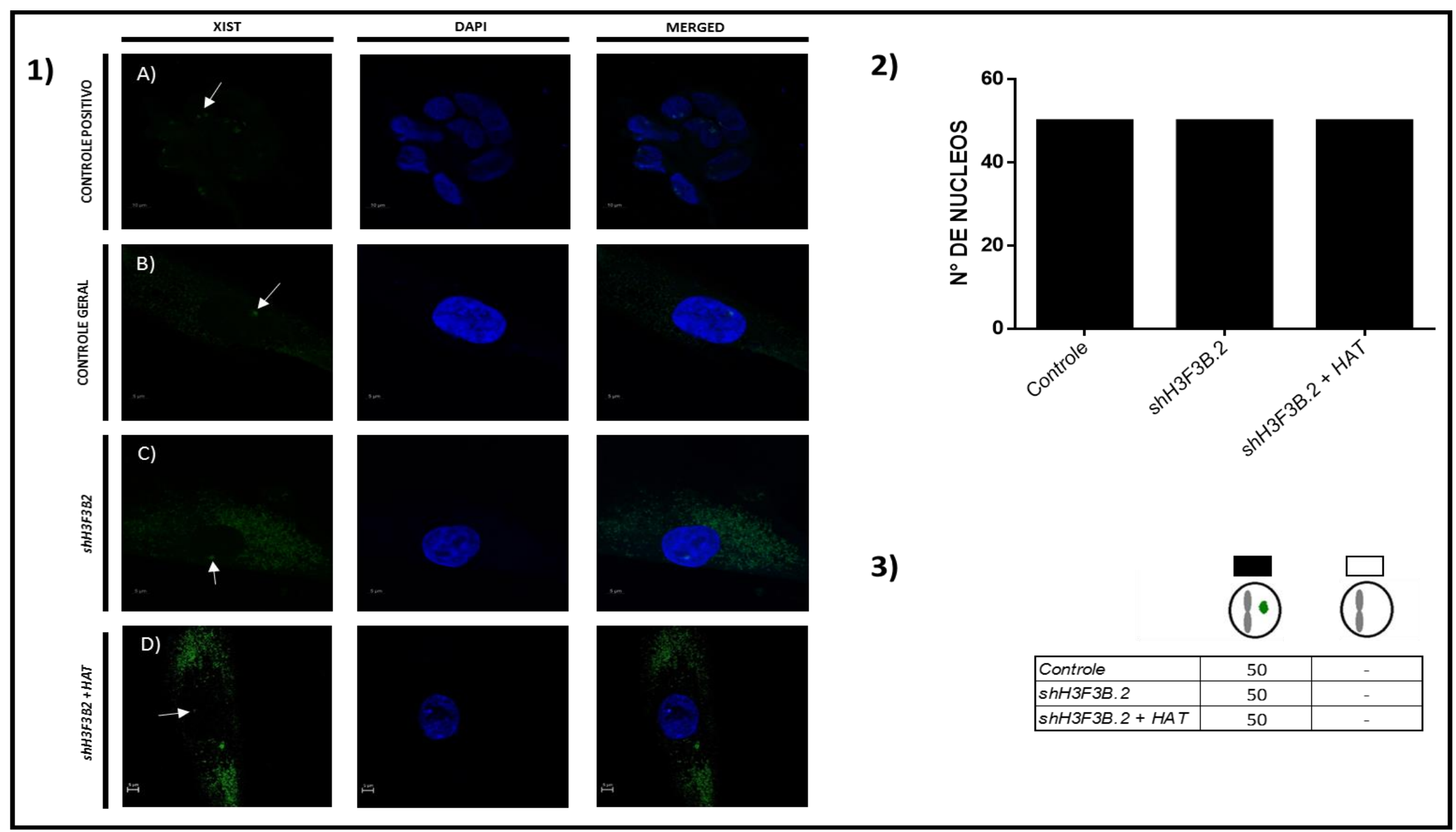

Figura 13 - Avaliação da presença da nuvem de XIST por RNA-FISH (Teste 1).1) A) Células HEK293T (controle positivo) marcadas com a sonda de RNA XIST; B) Células GM1661 marcadas com a sonda de RNA XIST; C) Células GM1661 transduzidas com o shH3F3B.2 marcadas com a sonda de RNA XIST; D) Células GM1661 transduzidas com o shH3F3B.2 + HAT marcadas com a sonda de RNA XIST;2) Histograma do número de núcleos positivos para a nuvem de XIST; 3) Esquema mostrando a relação entre células com presença/ausência da nuvem de XIST e número de núcleos analisados. Em azul marcação com DAPI e em verde marcação para o transcrito de XIST . Barra de aumento $=5$ micrômetros. 


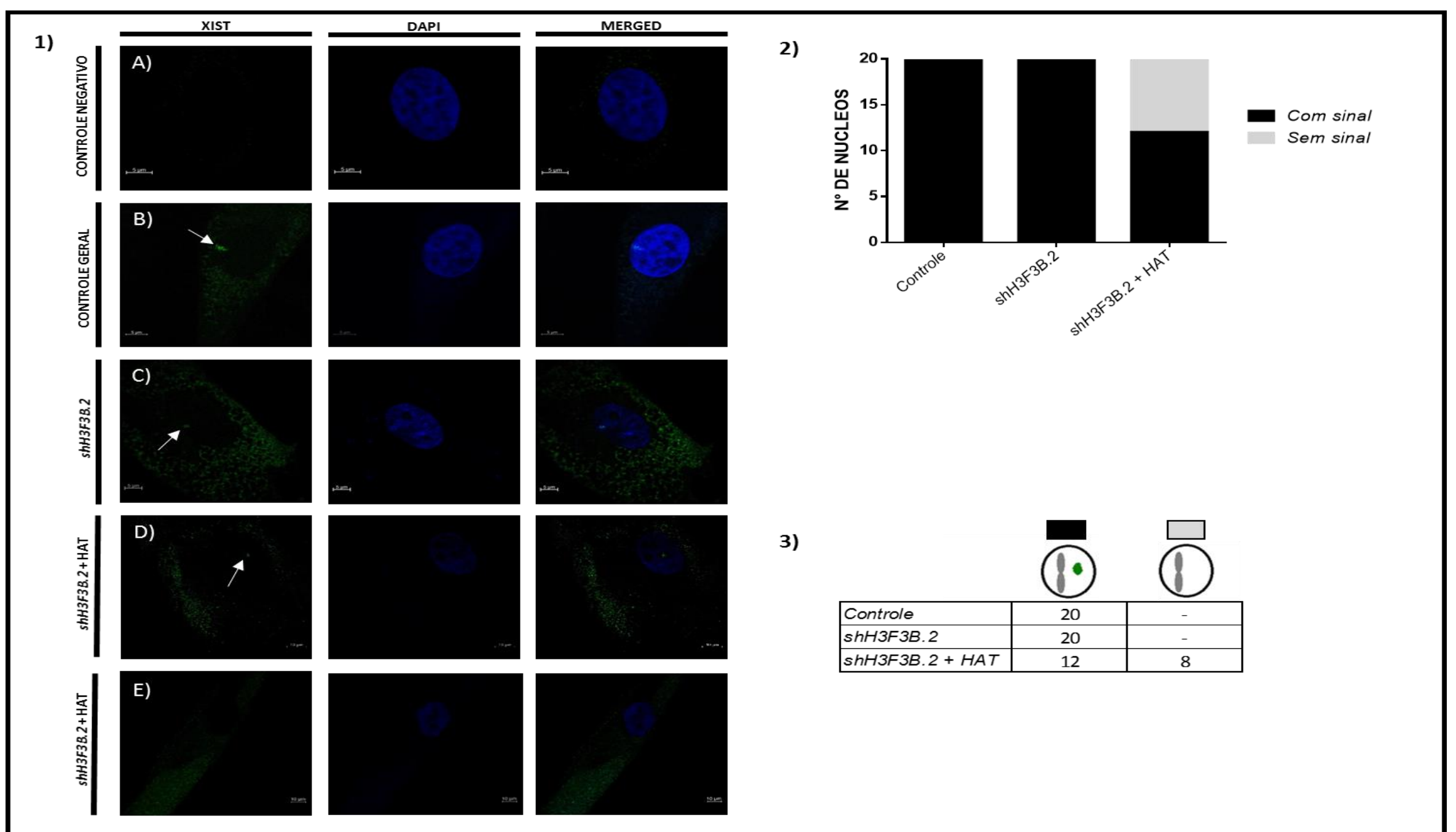

Figura 14 - Avaliação da presença da nuvem de XIST por RNA-FISH (Teste 2).1) A) Células GM1661 sem marcação (controle negativo); B) Células GM1661 marcadas com a sonda de RNA XIST; C) Células GM1661 transduzidas com o ShH3F3B.2 marcadas com a sonda de RNA XIST; D) Células GM1661 transduzidas com o shH3F3B.2+ HAT marcadas com a sonda de RNA XIST (com sinal); E) CélulasGM1661 transduzidas com o shH3F3B.2 + HAT marcadas com a sonda de RNA XIST (sem sinal). Em azul marcação com DAPI e em verde marcação para o transcrito de XIST. 2) Histograma do número de núcleos positivos para a nuvem de XIST; 3) Esquema mostrando a relação entre células com presença/ausência da nuvem de XIST e número de núcleos analisados. Barra de aumento $=5$ micrômetros. 
Por outro lado, foi observado que os níveis de expressão do transcrito de XIST nas células transduzidas com o shH3F3B.2 apresentaram uma diminuição de aproximadamente $60 \%$ (células na passagem 30 ), no entanto, as células que foram transduzidas com o mesmo shH3F3B.2 e selecionadas por 12 dias em HAT apresentavam uma diminuição maior, aproximadamente $91 \%$ (células na passagem 31) (Figura 15).

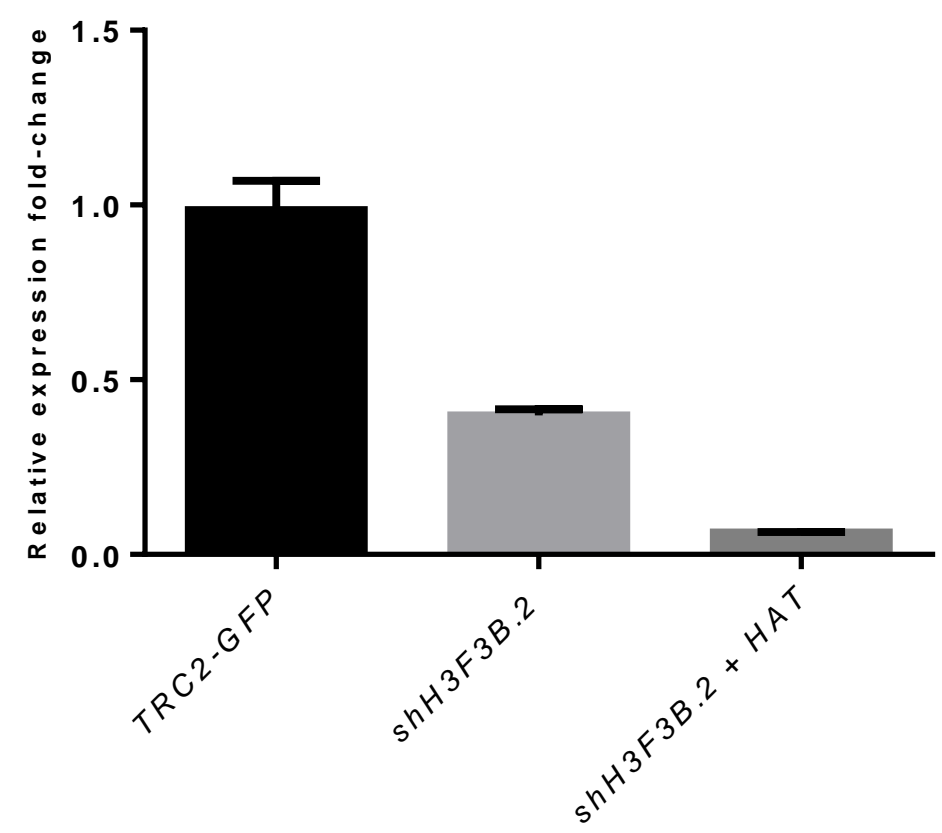

Figura 15 - Quantificação relativa por qPCR da expressão de XIST em células GM1661 transduzidas com shH3F3B.2 utilizando o gene ACTB como normalizador e a amostra "TRC2-GFP" como calibradora/referência. Os ensaios foram feitos em triplicata técnica.

\subsubsection{Avaliação da expressão do gene HPRT1}

Células heterozigotas para o gene HPRT1 (HPRT+/-) da linhagem GM1661 foram desviadas para que apresentassem a seguinte configuração: alelo HPRT- no $X$ ativo (Xa) (expressão do alelo mutante) e alelo HPRT + no X inativo (Xi) (inativação do alelo selvagem). 
A identificação de qual alelo HPRT era expresso nas amostras analisadas foi realizada por RT-PCR. Para tanto foram desenhados primers específicos para o gene HPRT1 com anelamento nos exons 1 e 4 (Figura 16). Células GM1661 cultivadas em 6TG deveriam amplificar apenas um fragmento de $653 \mathrm{pb}$, correspondente ao alelo mutante. No caso de reativação do alelo selvagem, as células, além de apresentarem o fragmento correspondente ao alelo mutante, também apresentariam um fragmento correspondente ao alelo selvagem de $363 \mathrm{pb}$.

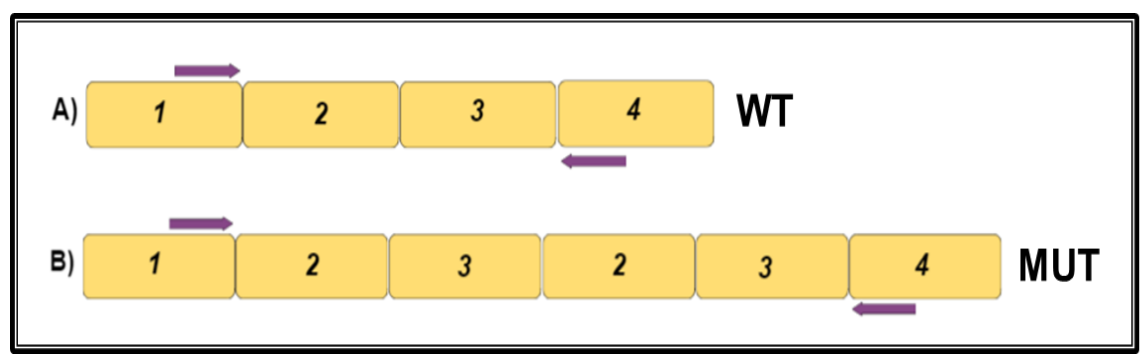

Figura 16 - Análise dos alelos do gene HPRT1 por RT-PCR. A) Diagrama do cDNA correspondente ao alelo selvagem (WT) para HPRT; B) Diagrama do cDNA correspondente ao alelo mutante (MUT) para HPRT. Foram desenhados oligonucleotídeos para anelar nos exons 1 e 4 resultando em fragmentos de $363 \mathrm{pb}$ para o alelo WT e 653pb para o alelo MUT.

Na Figura 17, podemos observar que as células desviadas para HPRTamplificaram o fragmento que seria esperado para células deficientes em HPRT (amostra 1). Já as células transduzidas com o shH3F3B.2 apresentaram dois tamanhos diferentes de fragmentos: um correspondente ao alelo selvagem (363 pb) e outro correspondente ao alelo mutante (653 pb), o que indicaria uma provável reativação do Xi (amostra 2). Além disso, para poder ter um controle positivo dos tamanhos dos fragmentos, analisamos o cDNA de células GM1660 não desviadas (fibroblastos primários obtidos da irmã da GM1661, que também apresentam a mesma mutação no gene HPRT1 e tem uma população heterozigota da mutação), que apresentou as duas bandas esperadas (amostra 3). 


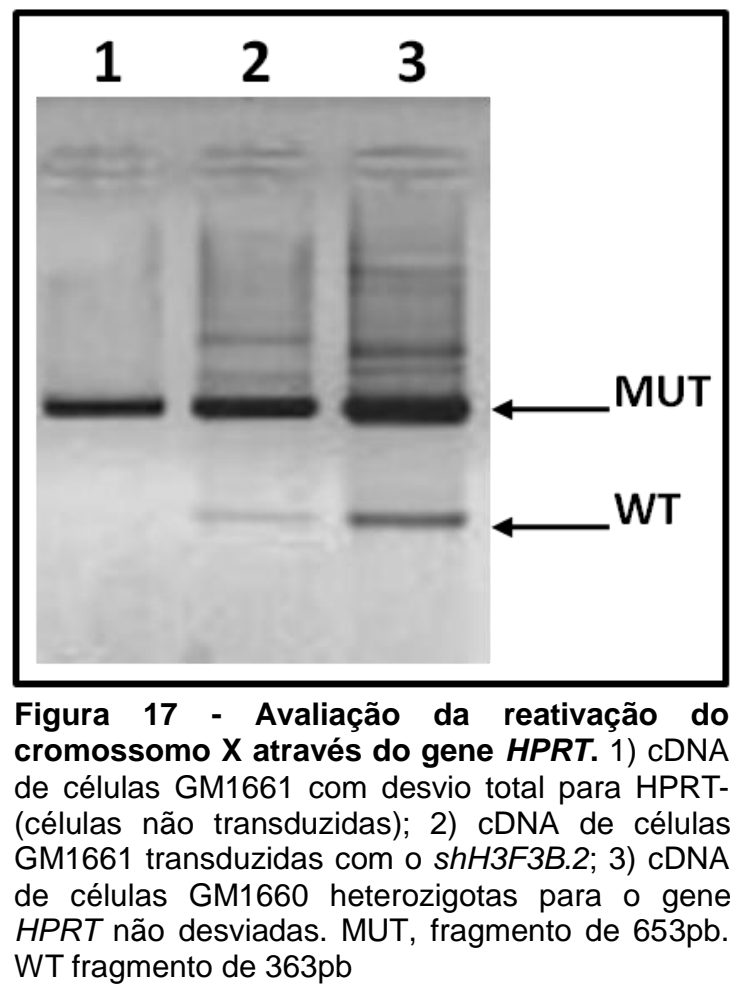

\subsubsection{Avaliação da expressão alelo-específica no cromossomo $X$}

\subsection{Avaliação da expressão alelo-específica do gene ATRX}

A detecção de expressão mono ou bi-alélica dos genes ligados ao cromossomo $X$ revela se há inativação do $X$ ou se ambos estão ativos, respectivamente. Para tanto, investigou-se a expressão alelo-específica de um gene do X utilizando-se SNPs em regiões codificadoras previamente identificados como heterozigotos para a linhagem GM1661 em trabalho realizado previamente em nosso laboratório: ATRX (rs3088074). ATRX já tem sido utilizado previamente por outros laboratórios para verificar reativação do Xi (Chaligné et al., 2015; Sarkar et al., 2015; Pasque et al., 2014). Para cada amostra realizou-se a extração de RNA e síntese de cDNA como descrito nos itens 3.6 e 3.7 respectivamente. Os ensaios foram feitos nas células GM1661 desviadas, nas células GM1661 transduzidas com o TRC2-GFP, nas células GM1661 desviadas e transduzidas com o shH3F3B.2 e nas células GM1661 desviadas, 
transduzidas com o shH3F3B.2 e cultivadas por 12 dias em HAT. Para poder determinar qual alelo estava sendo expresso no caso de reativação do Xi, chamamos de alelo referência ao alelo expresso no Xa das células GM1661 desviadas e alelo variante ao que se encontrava no Xi. Na Figura 18A, podemos observar que as amostras células GM1661 desviadas (B01-C01) e células GM1661 transduzidas com o TRC2-GFP (H01-A02) só apresentavam o alelo referência (C), confirmando assim o total desvio das células da linhagem GM1661. Além disso, com relação às amostras transduzidas com o shH3F3B.2 e selecionadas em HAT observamos que na amostra transduzida com o shH3F3B.2 (B02-C02) foi detectada apenas uma gota acima do threshold, assim como em uma das amostras controle negativo (B01) (Figura 18A). Por isso consideramos o resultado negativo. $O$ número de copias por microlitro de reação foi contado para cada duplicata de cada amostra (Figura 18B). 


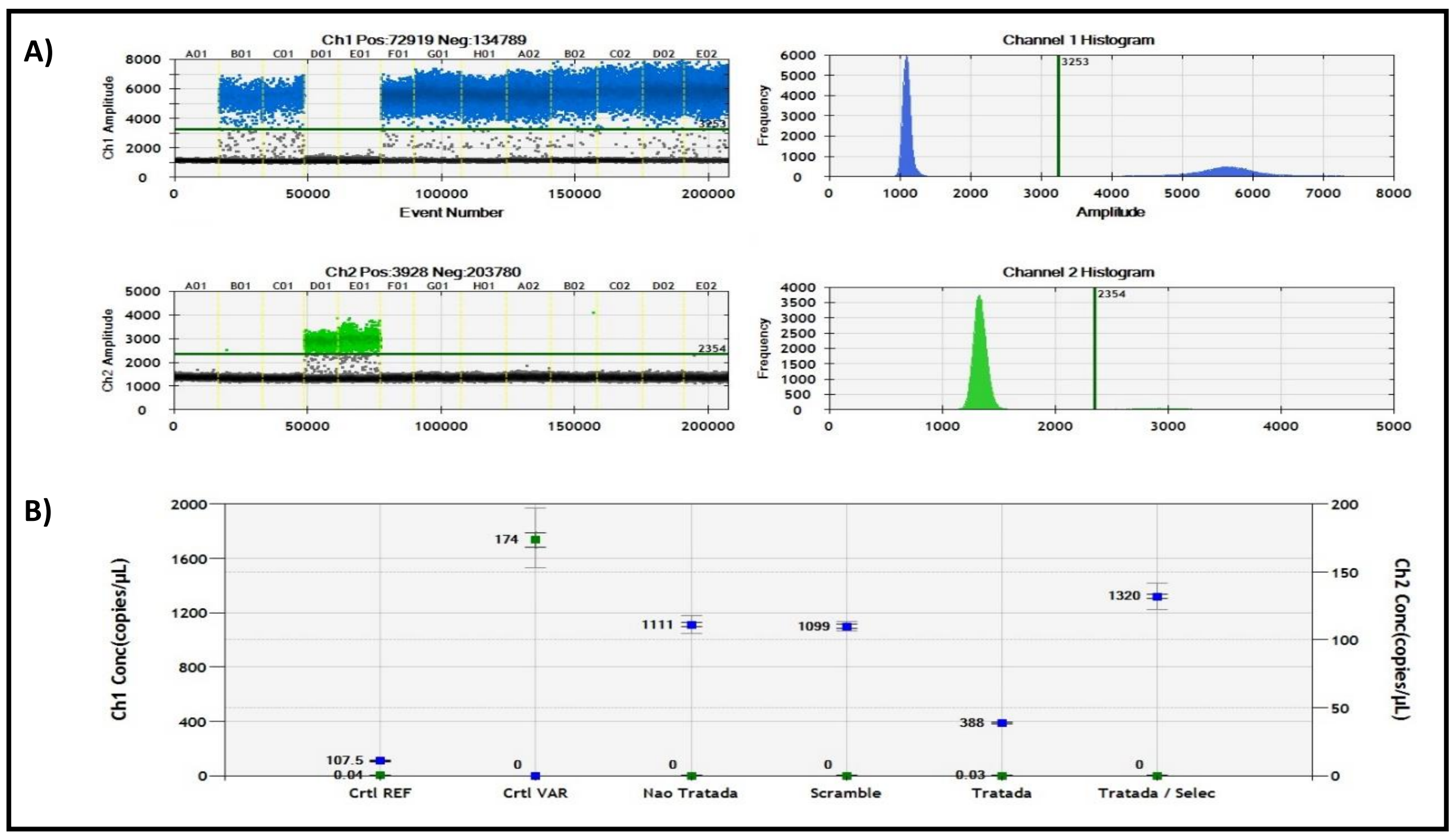

Figura 18 - Avaliação da expressão alelo-específica do gene ATRX. A) Gráficos superiores (Em azul): Análise do dotblot e histograma para a quantificação do número positivo e negativo de gotas para o alelo referência (C); Gráficos inferiores (Em verde): Análise do dotblot e histograma para a quantificação do número positivo e negativo de gotas para o alelo variante (G). A01: Controle negativo (NTC); B01-C01: Controle alelo referencia; D01-E01:Controle alelo variante; F01-G01: células GM1661 desviadas; H01A02: células GM1661 transduzidas com o TRC2-GFP (shScramble); B02-C02: GM1661 desviadas e transduzidas com o shH3F3B.2; D02-E02: células GM1661 desviadas, transduzidas com o shH3F3B.2 e cultivadas por 12 dias em HAT. B) Gráfico mostrando a média do número de copias por microlitro de reação para cada duplicatas. As gotas positivas e negativas foram determinadas usando um threshold de fluorescência determinado a partir das análises dos gráficos de dotblot e histograma para alelo. 
4.2.5.3.2 Avaliação da expressão alelo-específica ao longo do cromossomo $X$

Por conta de não terem sido detectadas mudanças de expressão do gene ATRX por ddPCR (item 4.3.5.3.1), decidimos utilizar a técnica de RNA-Seq para avaliar o perfil de expressão de um maior número de genes ao longo do cromossomo $X$, sendo que temos interesse na expressão dos genes que são submetidos à inativação. Na Tabela 4 encontram-se o número de reads obtidas para as amostras de células GM1661 desviadas e transduzidas com o TRC2-GFP (shScramble) (S3) e células GM1661 desviadas, transduzidas com o shH3F3B.2 e selecionadas em meio HAT (S2) utilizadas nas análises de expressão alelo-específica. Pode-se verificar que o processo de sequenciamento resultou num número total de reads de 139779746 e 119410422 para as amostras S2 e S3 respectivamente. As reads de baixa qualidade foram removidas da análise para que obtivéssemos uma maior confiança nas variantes detectadas. De maneira geral o filtro de qualidade manteve quase o $95 \%$ das reads originais. Das reads com qualidade adequada para análise de variante cerca de 92\% alinharam uma única vez contra o genoma de referencia $(\mathrm{Hg} 19)$.

Tabela 4 - Número de reads dos resultados de sequenciamento, de filtragem e dos alinhamentos

\begin{tabular}{|c|c|c|c|}
\hline Amostra & reads inicias & $\begin{array}{c}\text { reads com boa } \\
\text { qualidade }\end{array}$ & $\begin{array}{c}\text { Total de reads } \\
\text { alinhadas }\end{array}$ \\
\hline S2 & 139779746 & 110534844 & 104569647 \\
\hline S3 & 119410422 & 95615252 & 90339220 \\
\hline
\end{tabular}

Após análise dos SNPs pudemos ver que 5 genes mudaram seu padrão de expressão de monoalélico para bialélico na amostra transduzida com o shH3F3B.2e tratada com HAT (S2) (Figura 19). Com o intuito de ver se os 5 genes encontrados eram submetidos à ICX, estes foram classificados nos baseando em parâmetros previamente descritos por Balaton e colaboradores (2015) para os genes ligados ao cromossomo X. Dessa maneira, os genes foram classificados em genes que são submetidos e genes que escapam à ICX. Na Figura 19.1 podemos observar que os 
alelos alternativos (em vermelho) dos genes FHL1 e FLNA, descritos como submetidos à ICX (Carrel et al., 2005; Cotton et al., 2013), são responsáveis por 25\% e $40 \%$ da expressão total dos respectivos genes. No caso dos genes que escapam à IXC (JPX, SYAP1 e XG) (Carrel et al., 2005; Cotton et al., 2013), pudemos observar que a proporção de expressão do alelo alternativo estava entre 20 e 40\% (Figura 19.2). Ou seja, o nível de expressão entre os genes que escapam e aqueles que são submetidos a ICX são similares. Finalmente, ao verificar a localização dos genes informativos, observamos que estes estavam espalhados ao longo do cromossomo $\mathrm{X}$, sendo que os dois genes informativos que são submetidos à ICX se encontravam no braço longo do cromossomo junto com JPX, enquanto que SYAP1 e XG se encontravam no braço curto (Figura 19.3). Além disso, também procuramos a localização do HPRT1, gene que utilizamos como ferramenta de seleção das células que sofreram reativação do $\mathrm{Xi}$, sendo que este apresentava uma localização próxima aos genes que foram classificados como submetidos à ICX na amostra controle (S3) e que após transdução com shH3F3B.2 e seleção em HAT (amostra S2) apresentavam expressão bialélica (representado em vermelho na Figura 19.3). 


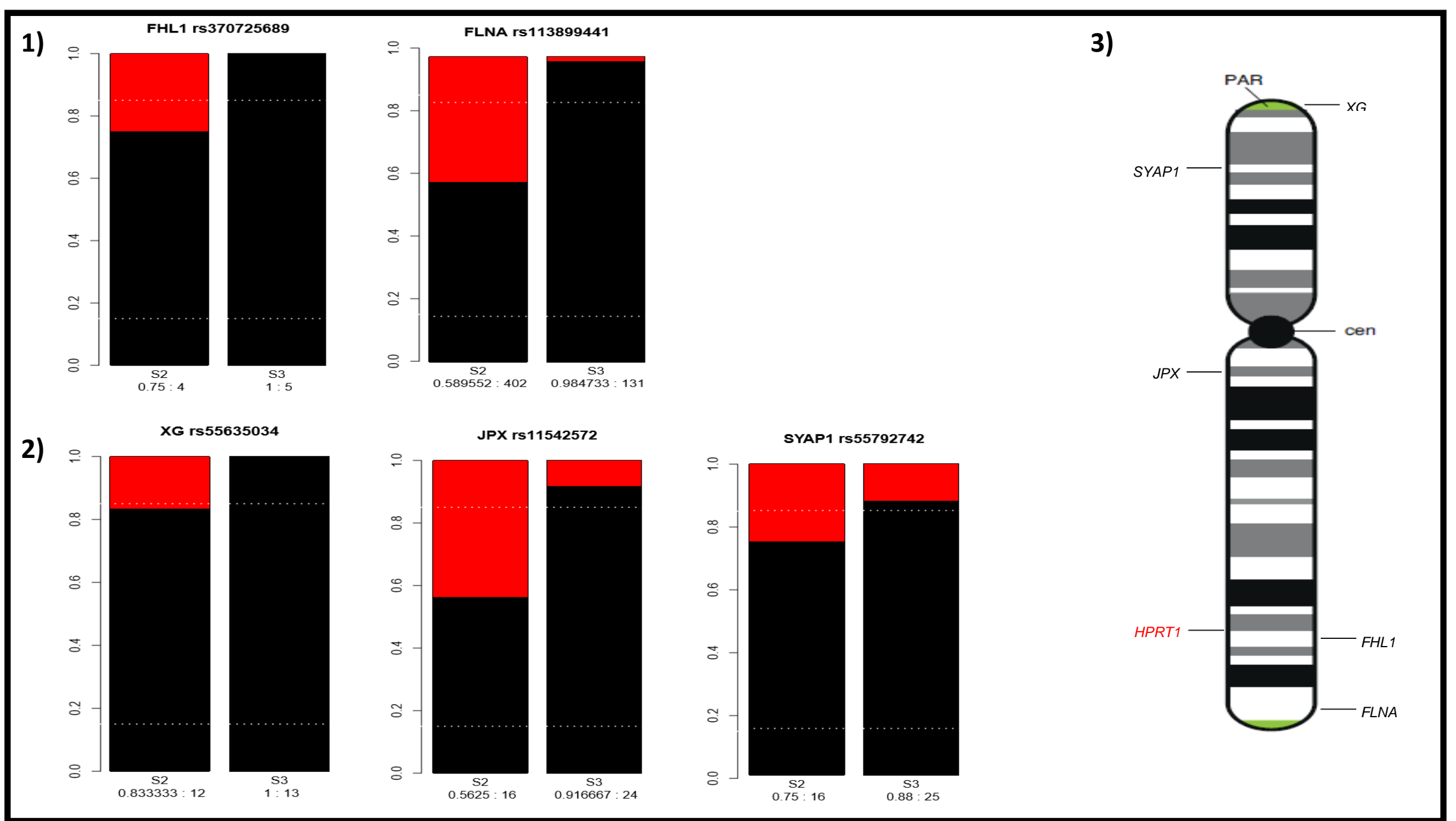

Figura 19 - Genes informativos de expressão bialélica. 1) Genes com expressão bialélica que são submetidos à inativação do cromossomo X. 2) Genes com expressão bialélica que escapam à inativação do cromossomo X. 3) Representação gráfica da posição dos genes informativos com expressão bialélica ao longo do cromossomo X. Em preto, representação da porcentagem do alelo referência (alelo encontrado no genoma referência); em vermelho, a porcentagem do alelo variante (alelo encontrado nas nossas amostras); em linhas pontilhadas brancas os thresholds estabelecidos ( 0.15 e 0.85 ) para determinar genes com expressão bialélica. Para cada gene informativo é mostrada a frequência do alelo referência e o número de reads encontrados. 


\subsection{Avaliação da expressão alelo-específica em cromossomos autossômicos}

Em geral, nos organismos diploides eucariotas, os genes dos cromossomos autossômicos expressam ambos os alelos herdados (materno e paterno) em simultâneo. Contudo, existem algumas exceções como os genes de expressão monoalélica aleatória (Gimelbrant et al., 2007), os quais podem ser usados como ferramenta para avaliar mudanças no padrão de expressão alélica das células. Assim, para verificar se a mudança de expressão alelo-especifica encontrada nas nossas células é um fenômeno exclusivo do cromossomo $\mathrm{X}$, genes informativos dos cromossomos autossômicos foram usados como controle das nossas análises. Na Figura 20 podemos observar o número e distribuição de genes que originalmente apresentavam a expressão de um dos seus alelos e que sofreram uma mudança no seu perfil de expressão alélica após o silenciamento do gene H3F3B e seleção em HAT. A maioria desses genes já haviam sido descritos como apresentando expressão monoalélica (representados em preto na figura 20), enquanto que alguns outros não tinham sido descritos antes (representados em cinza na Figura 20). A lista de genes que sofreram uma mudança no seu perfil de expressão alélica se encontra no anexo II. Estes dados indicam que o Knockdown do H3F3B (S2) altera o perfil de expressão alelo-especifico de genes ao longo de todo o genoma.

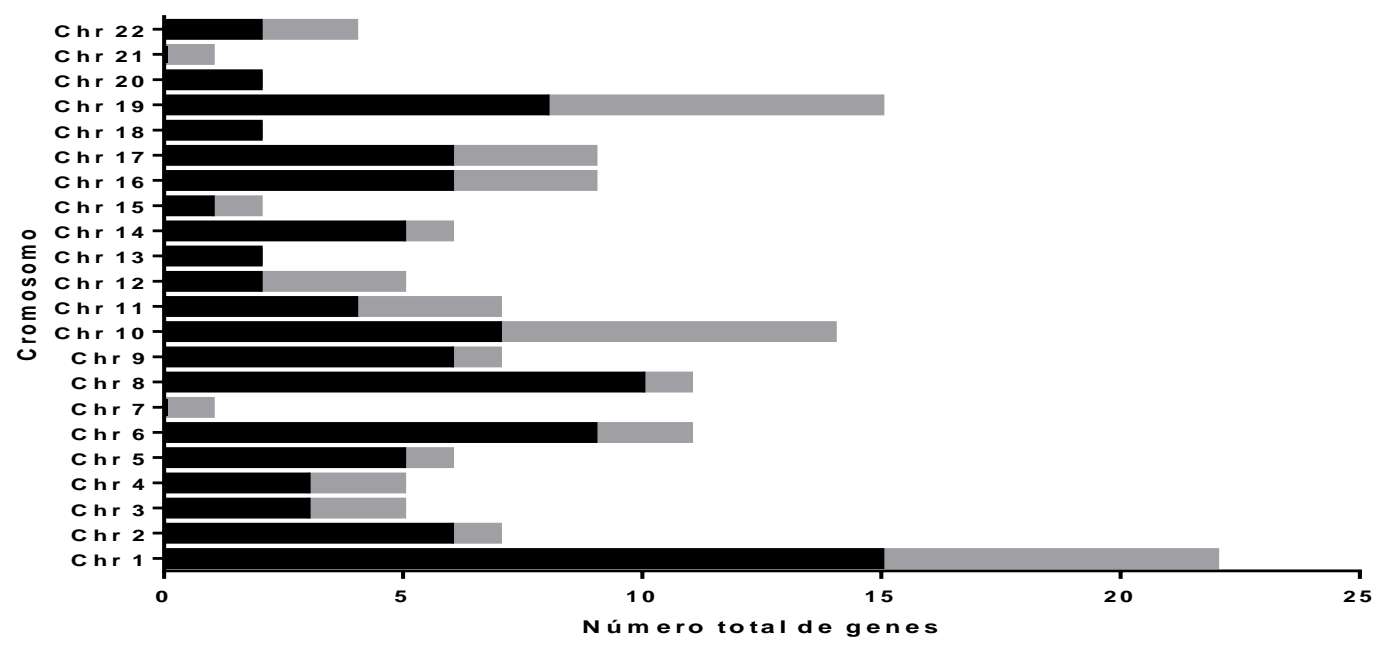

Figura 20 - Indução de expressão bialélica de genes nos cromossomos autossômicos. Gráfico representativo do número total de genes bialélicos em cromossomos autossômicos da linhagem GM1661 transduzida com shH3F3B.2 e tratada com HAT. Em preto, representação dos genes descritos na literatura como monoalélicos; Em cinza, representação dos genes ainda não descritos na literatura como monoalélicos. Na ausência de transdução e tratamento, a linhagem GM1661 apresenta expressão monoalélica desses genes. 
Também foi calculado o número de genes que apresentavam expressão bialélica em cada cromossomo na linhagem desviada e na mesma com o gene H3F3B silenciado. Todos os cromossomos autossômicos apresentaram uma porcentagem similar de genes bialélicos. Entretanto, o cromossomo $X$ apresenta uma porcentagem bem inferior de genes bialélicos (Tabela 5), corroborando que nossas células GM1661 foram selecionadas para expressar apenas um dos cromossomos $\mathrm{X}$.

Tabela 5 - Porcentagem de variantes anotadas com expressão bialélica nos cromossomos autossômicos e cromossomos sexuais

\begin{tabular}{|c|cc}
\hline Cromossomo & S2 & S3 \\
\hline chr1 & $50 \%$ & $46 \%$ \\
chr2 & $50 \%$ & $46 \%$ \\
chr3 & $51 \%$ & $47 \%$ \\
chr4 & $50 \%$ & $48 \%$ \\
chr5 & $52 \%$ & $48 \%$ \\
chr6 & $52 \%$ & $46 \%$ \\
chr7 & $54 \%$ & $49 \%$ \\
chr8 & $43 \%$ & $38 \%$ \\
chr9 & $52 \%$ & $47 \%$ \\
chr10 & $54 \%$ & $51 \%$ \\
chr11 & $52 \%$ & $47 \%$ \\
chr12 & $49 \%$ & $46 \%$ \\
chr13 & $51 \%$ & $47 \%$ \\
chr14 & $49 \%$ & $44 \%$ \\
chr15 & $48 \%$ & $46 \%$ \\
chr16 & $50 \%$ & $47 \%$ \\
chr17 & $50 \%$ & $45 \%$ \\
chr18 & $52 \%$ & $46 \%$ \\
chr19 & $48 \%$ & $45 \%$ \\
chr20 & $54 \%$ & $51 \%$ \\
chr21 & $63 \%$ & $59 \%$ \\
chr22 & $56 \%$ & $54 \%$ \\
chrX & $9 \%$ & $8 \%$ \\
\hline
\end{tabular}

* S2 - células transduzidas com shRNAs contra o gene H3F3B e selecionadas com HAT e S3 - células transduzidas com vetor scramble. 
Para poder avaliar se houve diferença na expressão global entre os genes do cromossomo $\mathrm{X}$ da amostra silenciada para o gene $H 3 F 3 B$ e selecionada em HAT (S2) e a amostra silenciada com vetor scramble (S3) seguimos o protocolo descrito no item 3.13.2. Na Figura 21, podemos observar que existe um aumento de expressão significativa nos genes presentes no intervalo de genes 125 a 226 na amostra com silenciamento para o gene $H 3 F 3 B$ e selecionada em HAT (S2) com relação à amostra controle (células transduzidas com o vetor scramble) (S3). Além disso, também podemos verificar que o gene que utilizamos como parte da ferramenta de seleção (HPRT) está presente na janela de genes que apresentaram uma expressão aumentada em relação ao controle, contudo está região não é significativa estatisticamente (Figura 21- linha vertical preta).

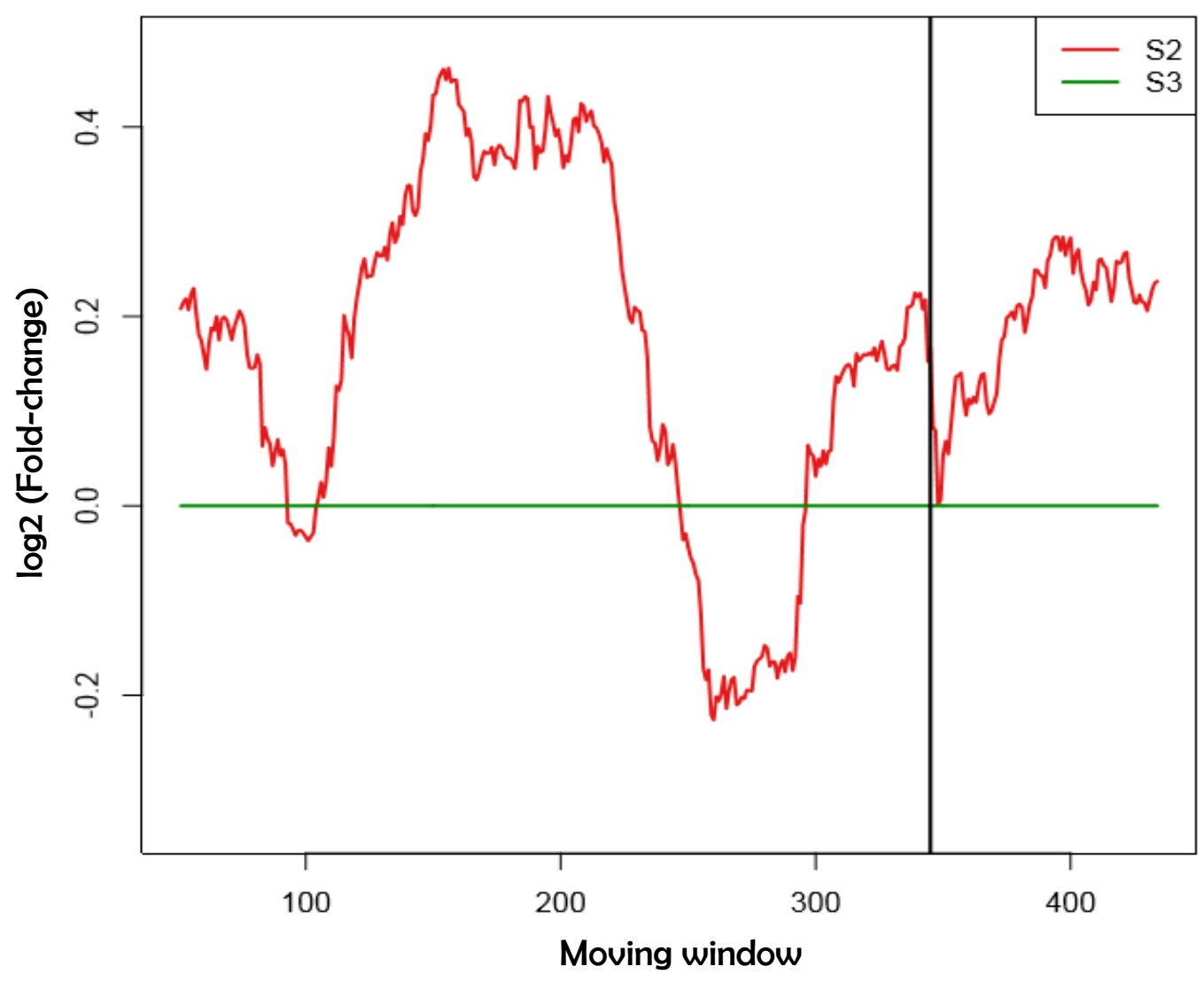

Figura 21 - Média móvel entre as amostras da linhagem GM1661. Em vermelho, S2 - células transduzidas com shRNAs contra o gene candidato e selecionadas com HAT, em verde, S3 - células transduzidas com scramble; em preto, linha representativa da localização do gene HPRT. 
Uma vez determinada a diferença de expressão significativa entre a amostra tratada (S2) e amostra controle (S3), decidimos localizar ao longo do cromossomo $\mathrm{X}$ todos os genes que apresentavam uma expressão aumentada em relação ao controle (S3) para poder determinar se a provável reativação do cromossomo $\mathrm{X}$ era um evento geral, que ocorria ao longo do $\mathrm{X}$ inteiro, ou um evento restrito a alguns genes. Dessa maneira, foram gerados 11 grupos segundo a localização dos genes, sendo que, 7 desses grupos tinham uma localização próxima ao centrômero (Figura 22). O que poderia ser explicado pela distribuição de H3.3 nos cromossomos em geral, sendo maiormente centromérica e telomérica.

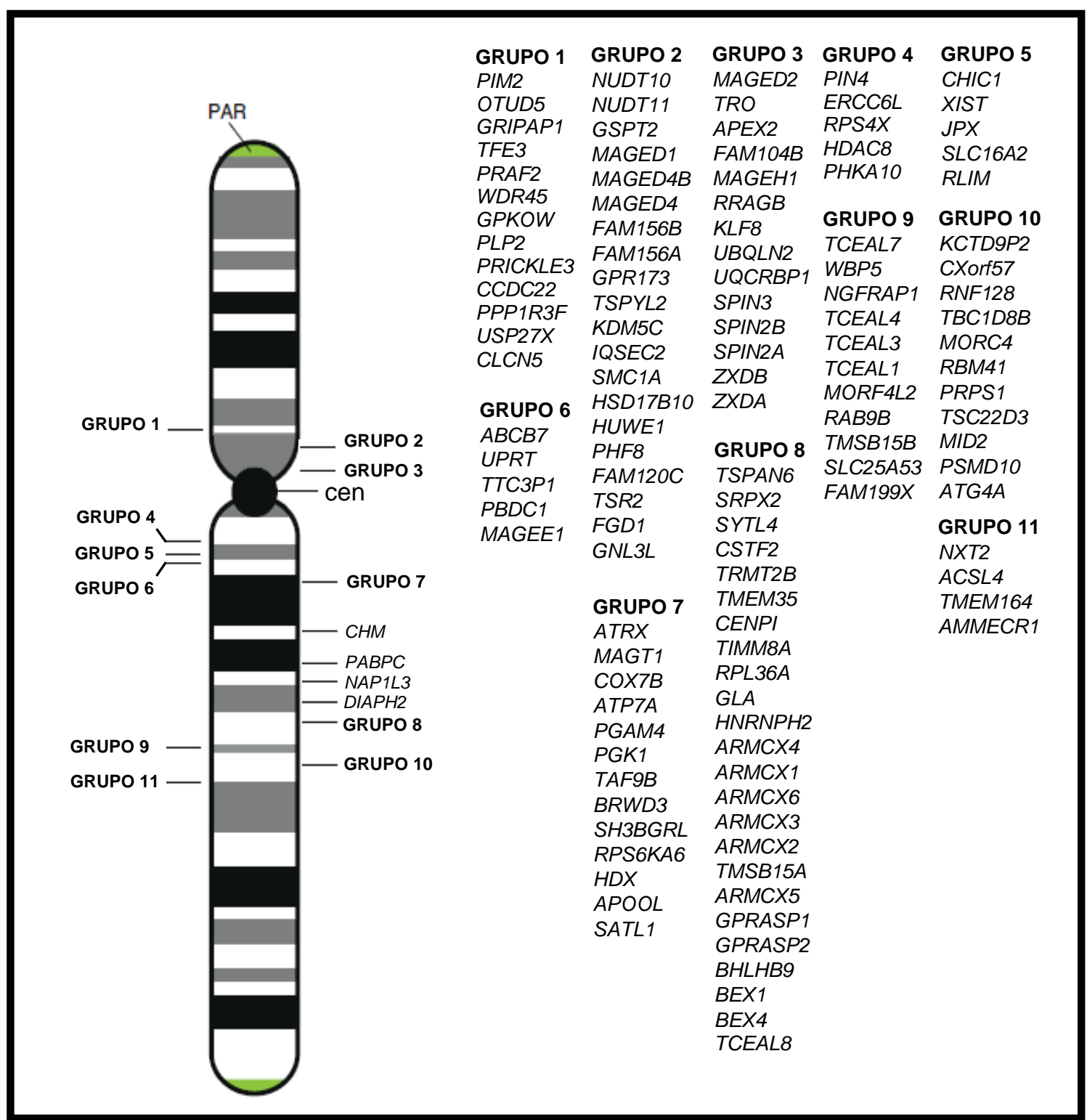

Figura 22 - Representação gráfica do grupo de genes com expressão aumentada na amostra de células transduzidas com shRNAs contra o gene candidato e selecionadas com HAT (S2) com relação a amostra controle (S3). Os genes foram agrupados segundo sua localização no cromossomo $\mathrm{X}$. 


\section{DISCUSSÃO}

\subsection{Metodologia usada}

O sistema de siRNAs é uma ferramenta valiosa para a identificação de reguladores genéticos em processos biológicos (Vergani, 2014). Contudo, múltiplos fatores exercem influência sob cada um dos passos experimentais adotados, podendo assim, afetar a qualidade e a significância biológica dos resultados obtidos (Sims et al., 2011; Strezoska et al., 2012, Zhang et al., 2004; Sack et al., 2016). Dessa maneira, cada um dos passos experimentais envolvidos na nossa validação de genes foram cuidadosamente otimizados, tais como meios de cultura, quantidade de vírus/célula (MOI), agente transdutor, entre outros. Por outro lado, como é mostrado nos nossos diferentes ensaios com as partículas de shRNA, nem todos os shRNAs utilizados para cada gene alvo apresentaram uma boa eficiência de knockdown, o que pode ocorrer em consequência do modelo celular utilizado e das diferenças entre as sequências dos diferentes shRNAs.

As curvas de crescimento geradas previamente no nosso laboratório para a linhagem GM1661 demostraram que o uso de HAT é eficiente para seleção de fibroblastos primários HPRT+, porém, não é possível ver uma depleção completa dessas células na placa de cultura ao finalizar o tratamento (Vergani, 2014), o que poderia sugerir que o desvio de nossas células não fosse completo para o fenótipo Xa hprt Xi $H^{H} R T$ e consequentemente uma pequena população destas apresentaria resistência ao tratamento com HAT. No entanto, os ensaios de ddPCR e RNA-Seq corroboraram que nossas células GM1661 previamente cultivadas em meio 6TG apresentavam um desvio total da ICX para o fenótipo Xa ${ }^{\text {hprt }} X_{i}{ }^{H P R T}$.

A análise dos efeitos do knockdown de $H 3 F 3 B$ a nível transducional através de ensaios de western blot não foi possível. H3.3 é uma proteína de 
localização nuclear que apresenta um papel importante no empacotamento de DNA (Szenker et al., 2011), assim o uso de um normalizador nuclear seria necessário para avaliar sua expressão. No entanto, isto não foi possível, pois os normalizadores nucleares caiam em duas categorias: 1) Fatores já descritos como parte da ICX (Lamina B1, YY1, HDAC1, PCNA) (Chen et al., 2016; Jeon \& Lee, 2011; Miller \& Grant, 2012; Oliveira et al., 2013), ou 2) Proteínas que sofriam alterações na sua expressão indiretamente ao alterar a expressão de H3.3 (TBP) (Chen et al., 2013). Por outro lado, o fato de não ter uma metodologia eficiente o suficiente para garantir a extração completa da proteína alvo e a quantidade necessária para os testes de western blot nos levaram a ter um viés nos resultados obtidos (dados não mostrados). Dessa maneira, resolvemos verificar a depleção da proteína H3.3 através de ensaios de imunofluorescência nas células transduzidas com shRNAs específico para $H 3 F 3 B$, sendo que observamos uma diminuição da proteína H3.3 nessa amostras ao compará-la com a amostra controle.

\subsection{Reativação do cromossomo Xi}

Os resultados obtidos das análises das marcas de repressão do Xi (perda do acúmulo de H3K27me3 e nuvem de XIST) não comportam com o que se tem descrito na literatura ao respeito das evidencias da reativação do $\mathrm{Xi}$, pois não vimos uma perda imediata da nuvem de XIST ou marcas de histona inativa uma vez que as células foram transduzidas com o gene candidato (Williams et al., 2011). No entanto, em 2015 Minaji e colaboradores avaliaram a importância de alguns fatores no processo de ICX por meio de ensaios de knockdown e concluíram que as marcas de cromatina inativa, como o acúmulo de H3K27me3, poderiam ser perdidas em longo prazo. No caso dos nossos resultados da avaliação da perda da nuvem de XIST, um estudo realizado por Vallot e colaboradores (2015) reportou que hiPSCs sofriam erosão espontânea da ICX e que no caso de reativação do Xi a perda da nuvem de XIST se dava por erosão ao longo das passagens do cultivo, o que explicaria porque vemos primeiro uma diminuição na expressão de XIST (passagens 29 a 31) e depois uma perda da nuvem de XIST em passagens mais tardias (passagens 30 a 35). Por outro lado, 
não existem estudos que relatem o que aconteceria se reativássemos o Xi de uma célula somática.

Os dados obtidos após análise da expressão alelo-específica para o gene ATRX não mostraram uma mudança na expressão alélica deste. Mesmo assim, nao se pode descartar uma reativação parcial do Xi. Dessa maneira, uma análise da expressão global do cromossomo $X$ foi necessária para poder confirmar uma provável reativação do Xi. As análises dos dados de RNA-Seq mostraram que 5 genes apresentaram uma mudança na expressão alelo-especifica, sendo que, estes tinham uma expressão monoalélica na amostra controle (S3) e mudaram para uma expressão bialélica na amostra com knockdown para $H 3 F 3 B$ e selecionada em HAT (S2). É importante assinalar que 4 destes genes apresentaram uma localização próxima à região telomérica (SYAP1, XG, FHL1 e $F L N A$ ), enquanto que só um apresentou uma localização mais centromérica (JPX). Uma provável explicação para esta distribuição pode ser o fato de H3.3 ser predominantemente incorporada, independentemente da replicação, nas regiões pericêntrica e teloméricas dos cromossomos (Delbarre et al., 2013; Drane et al., 2010; Goldberg et al., 2010). O que levaria a sugerir que estas regiões seriam mais propensas a expressão gênica no caso de um afrouxamento da cromatina pela falta de $\mathrm{H} 3.3$.

Por outro lado, uma vez determinada a localização destes genes informativos, decidimos verificar se existia algum padrão de reativação, visto que já há indícios na literatura de um estudo onde a reativação do Xi é restrita a determinadas áreas do cromossomo. Em 2015, Vallot e colaboradores avaliaram a expressão alelo-específica de genes ligados ao cromossomo $\mathrm{X}$ em hiPSC e mostraram que a reativação de genes era preferencialmente ligada a domínios ricos em H3K27me3. Nos nossos experimentos foi possível observar que os 2 genes que são submetidos a ICX ( $F H L 1$ e FLNA) estavam próximos a região telomérica do braço longo e também estavam localizados numa região próxima ao gene $H P R T$, o que nos leva a sugerir um afrouxamento da heterocromatina na região telomérica do braço longo do $X$ e uma provável reativação desta, principalmente por três motivos. Primeiro, H3.3 funciona como um repressor de transcrição na região telomérica (Goldberg et al., 2010). Segundo, os dados de 
RT-PCR para o gene HPRT mostram que a amostra com knockdown para H3F3B amplificava um fragmento para o alelo selvagem de HPRT. Finalmente, as análises de expressão global feitas na amostra com knockdown para H3F3B e selecionadas em HAT (S2) mostram que o gene HPRT se encontra numa região que apresentava uma expressão aumentada em relação a amostra controle (S3), sugerindo assim, uma expressão do alelo submetido a inativação. Porém, mais analises da expressão alelo-específica e ensaios de transcrito nascente para o gene HPRT deveram ser feitos para corroborar esses resultados.

Ainda dentre os dados de análise da expressão alelo-específica, também foram avaliados os genes informativos nos cromossomos autossômicos, visto que na literatura estes são usados como controle para avaliar se o silenciamento de nosso gene candidato apresenta um papel exclusivamente relacionado com a IXC (Keniry et al., 2016; Lessinga et al., 2016; Yang et al., 2015). Nas nossas análises os 22 cromossomos autossômicos apresentaram uma mudança no padrão de expressão alelo-especifica após silenciamento do gene $H 3 F 3 B$ e seleção em HAT. Na literatura a maioria de trabalhos que estudam candidatos a estar envolvidos na ICX não encontram uma mudança nos níveis de expressão dos cromossomos autossômicos (Bhatnagar et al., 2014; Minajigi et a., 2015). Contudo, em 2015 um trabalho feito por Yang e colaboradores demostrou que o silenciamento de Firre em células embrionárias de camundongo produzia um aumento significativo da expressão de genes nos cromossomos autossômicos. Por outro lado, em 2016, Lessinga e colaboradores realizaram uma triagem funcional em células de camundongos para identificar compostos que poderiam reativar o Xi, assim nas suas análises de RNA-Seq utilizaram o cromossomo 13 (Chr. 13) como controle de expressão alelo-específica, pois este apresenta um tamanho similar ao cromossomo $\mathrm{X}$, e encontraram que a regulação dos genes no Chr. 13 sofria alterações após tratamento. No nosso experimento, a mudança na expressão alelo-específica dos autossomos pode se dever ao fato da proteína H3.3 apresentar um papel regulatório em vários processos ligados à cromatina que acontecem fora da fase S do ciclo celular (Goldberg et al. 2010; Ray-Gallet et al., 2011). De fato, H3.3 apresenta uma função na plasticidade transcricional das células, pois é necessária tanto para manter a memória transcricional destas 
(Ng \& Gurdon, 2008) como para mudar o seu estado transcricional (Jullien et al., 2012).

A análise dos dados de avaliação dos níveis de expressão ao longo do cromossomo $X$ sugere que só determinados intervalos de genes expressos na amostra com knockdown para H3F3B e selecionada em HAT (S2) sofrem uma superexpressão em relação à amostra controle (S3). Existem já alguns indícios na literatura que sugerem que a reativação do cromossomo $X$ pode ser parcial $e$ ligada a marcas epigenéticas. Em 2015, Vallot e colaboradores avaliaram o padrão de expressão alélica de genes ligados ao cromossomo $X$ em células hiPSC e encontraram que todos os genes que foram considerados como reativados estavam preferencialmente localizados em regiões ricas em H3K27me3. Por outro lado, segundo a classificação de Balaton, 90\% dos genes que apresentavam superexpressão na amostra S2 era submetido a ICX (Balaton et al., 2015). Ao investigar a função destes genes no genecard (http://www.genecards.org/), encontramos que 60\% destes apresentavam funções relacionadas com processo de manutenção da célula como apoptose e ciclo celular, um 30\% eram usados como marcadores de diferentes tipos de câncer ou doenças ligadas ao X e um 10\% apresentavam função como remodeladores de cromatina (Ver Anexo III). Por outro lado, ao localizar estes genes informativos no cromossomo $\mathrm{X}$, pudemos observar que a maioria deles tinha uma localização pericêntrica, portanto a expressão aumentada destes poderia ser devido ao fato de H3.3 ter sido depletado nas nossas amostras, gerando assim um afrouxamento da heterocromatina da região.

\subsection{Genes candidatos}

É importante assinalar que a proteína H3.3 é codificada por dois genes (H3F3A e H3F3B), entretanto, o grau de expressão destes é tecido dependente (Lindroth e Plass, 2013). Assim, por exemplo, um estudo realizado com fibroblastos embrionários de camundongo (MEF) demonstrou que o knockout do gene $H 3 f 3 b$ reduzia drasticamente a produção da proteína $H 3.3$, ainda que o gene HЗfЗa não sofrera nenhuma alteração. De fato, as células com Knockout para $H 3 f 3 b$ e não para $H 3 f 3 a$, apresentaram uma série de problemas, como 
anormalidades nos cromossomos, problemas no ciclo celular e mudanças gerais no trascriptoma, o que sugere um papel fundamental da proteína H3.3 na regulação da atividade transcricional de genes em geral (Bush et al., 2013). Nossos resultados também sugerem que H3.3 é uma proteína importante para o controle epigenético da célula, pois sua depleção produz uma mudança no perfil de expressão de genes ao longo de todo o genoma.

Atualmente, sabe-se que inúmeros tipos de câncer apresentam alterações no processo de inativação do X. Em 2006, Richardson e colaboradores usaram um modelo de câncer de mama para demonstrar que aproximadamente um 50\% das células tumorais apresentam uma duplicação do $X$ ativo e perda do Xi. Sete anos depois, Jäger e colaboradores (2013) demonstraram que o cromossomo $X$ inativo apresenta mais mutações que qualquer cromossomo autossômico. Por outro lado, um estudo que utilizou a técnica de Knockout in vivo do RNA Xist em células hematopoiéticas de camundongo, demonstrou que a perda deste podia acarretar o desenvolvimento de câncer (Yildirim et al., 2013). Ao mesmo tempo, diversos estudos já têm relacionado alterações nos níveis de expressão do gene H3F3B com tumorigênese e alterações na manutenção da inativação do Xi (Bender et al., 2013; Chan et al., 2013; Lana et al., 2015). Outro trabalho que relaciona os níveis de expressão do gene $H 3 F 3 B$ e alterações na ICX é o trabalho feito por Lewis e colaboradores (2013), o qual demonstrou que mutantes para H3.3K27 apresentam modificações em marcas epigenéticas que são normalmente ligadas à cromatina inativa (PCR2 e H3K27me3).

Em nossos testes, não houve nenhuma evidencia que relacione $A S F 1 A$ à manutenção da ICX em humanos, contudo, isto pode ter sido em decorrência dos shRNAs usados e não pelo próprio fato deste não estar envolvido no processo de ICX. Na literatura, existem algumas evidências que sugerem a ASF1A como fator provável da ICX. Primeiramente, a proteína ASF1A faz parte do complexo SAHF, domínios relacionados à heterocromatina facultativa em células senescentes (Zhang et al., 2007). Depois, o complexo HIRA, que já tem função descrita dentro da ICX, trabalha em conjunto com a proteína ASF1A para montar/desmontar o arcabouço da cromatina e ambas são relacionadas com a 
ativação/repressão a nível transcricional de genes. Por último, deve se mencionar que uma triagem feita em 2015 por Minkovsky e colaboradores mencionou a ASF1A como provável candidato a estar envolvido na ICX, no entanto, os estudos de validação para confirmação do seu papel na ICX não foram feitos.

$\mathrm{Na}$ literatura existem vários trabalhos que mencionam as interações que existem entre H3F3B e ASF1A (Elsässer et al., 2014; Rai et al., 2011; Ricketts et al., 2015). Contudo, não foi possível realizar um teste de sinergismo entre ambos os genes, pois estes apresentavam o mesmo antibiótico para seleção após transdução. Dessa maneira, partículas lentivirais de shRNAs para os genes H3F3B e ASF1A com diferentes antibióticos de seleção devem ser usadas em conjunto, pois ainda que nossos resultados até agora indicam que o gene ASF1A não seria um candidato a estar envolvido na manutenção do ICX; estes (H3F3B e ASF1A) poderiam ter possíveis efeitos sinergísticos no processo de manutenção da ICX em humanos. 


\section{CONCLUSÕES}

Nos testes de validação realizados nas células que sofreram knockdown para o gene $H 3 F 3 B$ foi possível ver múltiples indícios de uma provável reativação do $\mathrm{Xi}$, visto que uma pequena população das suas células mostraram sobrevivência ao cultivo em meio HAT, perderam marcas de inativação como RNA XIST e mostraram uma mudança no perfil de expressão alelo-específico. $O$ que sugere um provável papel do gene $H 3 F 3 B$ na manutenção do $\mathrm{XCl}$ em humanos.

No caso da validação das células que sofreram knockdown do gene ASF1A não foi possível observar nenhuma modificação no fenótipo destas ao cultivá-las em meio HAT, assim, os ensaios de avaliação da reativação do Xi não foram levados a frente.

Finalmente, nos testes de avaliação da expressão alelo-específica dos cromossomos autossômicos nas células que sofreram silenciamento para 0 gene $H 3 F 3 B$, todos os cromossomos apresentaram uma mudança no seu perfil de expressão após silenciamento e seleção em HAT, mostrando assim que H3.3 apresenta funções de remodelamento epigenético gerais e não só para a ICX. 


\section{REFERÊNCIAS*}

Agez M, Chen J, Guerois R, van Heijenoort C, Thuret JY, Mann C, Ochsenbein F. Structure of the histone chaperone ASF1 bound to the histone H3 C-terminal helix and functional insights. Structure. 2007; 15(2):191-99.

Balaton BP, Cotton AM, Brown CJ. Derivation of consensus inactivation status for Xlinked genes from genome-wide studies. Biol Sex Differ. 2015; 6:35.

Banumathy G, Somaiah N, Zhang R, Tang Y, Hoffmann J, Andrake M, Ceulemans $H$, Schultz D, Marmorstein R, Adams PD. Human UBN1 is an ortholog of yeast Hpc2p and has an essential role in the HIRA/ASF1a chromatinremodeling pathway in senescent cells. Mol Cell Biol. 2009; 29(3):758-70.

Barakat TS, Gunhanlar N, Pardo CG, Achame EM, Ghazvini M, Boers R, Kenter A, Rentmeester E, Grootegoed JA, Gribnau J. RNF12 Activates Xist and Is Essential for X Chromosome Inactivation. PLoS Genet. 2011; 7(1):e1002001.

Barr ML, Bertram EG. A morphological distinction between neurones of the male and female, and the behaviour of the nucleolar satellite during accelerated nucleoprotein synthesis. Nature. 1949; 163(4148):676.

Bender S, Tang Y, Lindroth AM, Hovestadt V, Jones DT, Kool M, Zapatka M, Northcott PA, Sturm D, Wang W, Radlwimmer B, Hojfeldt JW, Truffaux N, Castel D, Schubert S, Ryzhova M, Seker-Cin H, Gronych J, Johann PD, Stark S, Meyer J, Milde T, Schuhmann M, Ebinger M, Monoranu CM, Ponnuswami A, Chen S, Jones C, Witt O, Collins VP, Von DA, Jabado N, Puget S, Grill J, Helin K, Korshunov A, Lichter P, Monje M, Plass C, Cho YJ, Pfister SM. Reduced H3K27me3 and DNA hypomethylation are major drivers of gene expression in K27M mutant pediatric high-grade gliomas. Cancer Cell. 2013; 24:660-72.

Beutler E, Yeh M, Fairbanks VF. The normal human female as a mosaic of Xchromosome activity: studies using the gene for C-6-PD-deficiency as a marker. Proc Natl Acad Sci. 1962; 48:9-16.

Bhatnagar S, Zhu X, Ou J, Lin L, Chamberlain L, Zhu LJ, Wajapeyee N, Green MR. Genetic and pharmacological reactivation of the mammalian inactive $X$ chromosome. Proc Natl Acad Sci. 2014; 111(35):12591-98.

Blewitt ME, Gendrel AV, Pang Z, Sparrow DB, Whitelaw N, Craig JM, Apedaile A, Hilton DJ, Dunwoodie SL, Brockdorff N, Kay GF, Whitelaw E. SmcHD1, containing a structural-maintenance-of-chromosomes hinge domain, has a critical role in X inactivation. Nat Genet. 2008; 40(5):663-69.

Boggs BA, Connors B, Sobel RE, Chinault AC, Allis CD. Reduced levels of histone $\mathrm{H} 3$ acetylation on the inactive $X$ chromosome in human females. Chromosoma. 1996; 105(5):303-9.

${ }^{*}$ De acordo com: International Committee of Medical Journal Editors. [Internet]. Uniform requirements for manuscripts submitted to biomedical journals. [2011 Jul 15]. Available from: http://www.nlm.nih.gov/bsd/uniform_requirements.htlm 
Bolger AM, Lohse M, Usadel B. Trimmomatic: a flexible trimmer for Illumina sequence data. Bioinformatics. 2014; 30(15):2114-20.

Borensztein M, Syx L, Ancelin K, Diabangouaya P, Picard C, Liu T, Liang JB, Vassilev I, Galupa R, Servant N, Barillot E, Surani A, Chen CJ, Heard E.Xistdependent imprinted $X$ inactivation and the early developmental consequences of its failure. Nat Struct Mol Biol. 2014; 24(3):226-33.

Brown CJ, Lafreniere RG, Powers VE, Sebastio G, Ballabio A, Pettigrew AL, Ledbetter DH, Levy E, Craig IW, Willard HF. Localization of the $X$ inactivation centre on the human X chromosome in Xq13. Nature. 1991; 349(6304):82-84.

Bull JJ, Vogt RC. Temperature-dependent sex determination in turtles. Science. 1979; 206(4423):1186-8.

Bush KM, Yuen BT, Barrilleaux BL, Riggs JW, O'Geen H, Cotterman RF, Knoepfler PS. Endogenous mammalian histone H3.3 exhibits chromatin-related functions during development. Epigenetics Chromatin. 2013; 6:7.

Carrel L, Willard HF. X-inactivation profile reveals extensive variability in X-linked gene expression in females. Nature. 2005;434(7031):400-4.

Casas-Delucchi CS, Brero A, Rahn HP, Solovei I, Wutz A, Cremer T, Leonhardt $\mathrm{H}$, Cardoso MC. Histone acetylation controls the inactive $\mathrm{X}$ chromosome replication dynamics. Nat Commun. 2011; 2:222.

Chadwick BP, Willard H.F. Multiple spatially distinct types of facultative heterochromatin on the human inactive $X$ chromosome. Proc. Natl. Acad. Sci. 2004 ; 101(50): 17450-17455.

Charlesworth B. The evolution of sex chromosomes. Science. 1991; 8, 931-933.

Chaligné R, Popova T, Mendoza-Parra MA, Saleem MA, Gentien D, Ban K, Piolot T, Leroy O, Mariani O, Gronemeyer H, Vincent-Salomon A, Stern MH, Heard E. The inactive $X$ chromosome is epigenetically unstable and transcriptionally labile in breast cancer. Genome Res. 2015; 25(4):488-503.

Chan KM, Fang D, Gan H, Hashizume R, Yu C, Schroeder M, Gupta N, Mueller $S$, James CD, Jenkins $R$, et al. The histone H3.3K27M mutation in pediatric glioma reprograms H3K27 methylation and gene expression. Genes Dev. 2013; 27:985-90.

Chan KM, Zhang H, Malureanu L, van Deursen J, Zhang Z. Diverse factors are involved in maintaining $X$ chromosome inactivation. Proc Natl Acad Sci. 2011; 108(40):16699-704. Chang SC, Brown CJ. Identification of regulatory elements flanking human XIST reveals species differences. BMC Mol Biol. 2010; 11:20.

Chaumeil J, Le Baccon P, Wutz A, Heard E. A novel role for Xist RNA in the formation of a repressive nuclear compartment into which genes are recruited when silenced. Genes Dev. 2006; 20(16):2223-37.

Chen M, Li G, Yan J, Lu X, Cui J, Ni Z, Cheng W, Qian G, Zhang J, Tu H. Reevaluation of glypican-3 as a serological marker for hepatocellular carcinoma. Clin Chim Acta. 2013; 423:105-11. 
Chu C, Zhang QC, da Rocha ST, Flynn RA, Bharadwaj M, Calabrese JM, Magnuson T, Heard E, Chang HY. Systematic discovery of Xist RNA binding proteins. Cell. 2015; 161:404-16.

Clemson CM, Chow JC, Brown CJ, Lawrence JB Stabilization and Localization of Xist RNA are Controlled by Separate Mechanisms and are Not Sufficient for $X$ Inactivation. J Cell Biol. 1998; 142(1):13-23.

Conover DO, Heins SW. Adaptive variation in environmental and genetic sex determination in a fish. Nature. 1987; 326(6112):496-8.

Costanzi C, Pehrson JR. Histone macroH2A1 is concentrated in the inactive $X$ chromosome of female mammals. Nature. 1998; 393:599-601.

Cotton AM, Ge B, Light N, Adoue V, Pastinen T, Brown CJ. 2013. Analysis of expressed SNPs identifies variable extents of expression from the human inactive X chromosome. Genome Biol 14: R122.

Creppe C, Janich P, N. Cantariño, M. Noguera, V. Valero, E. Musulén, et al., MacroH2A1 regulates the balance between self-renewal and differentiation commitment in embryonic and adult stem cells., Mol Cell Biol. 2012; 32:1442-52.

Csankovszki G, Nagy A, Jaenisch R. Synergism of Xist RNA, DNA methylation, and histone hypoacetylation in maintaining $X$ chromosome inactivation. $J$ Cell Biol. 2001; 153:773-84.

Delbarre E, Ivanauskiene K, Kuntziger T, Collas P. DAXX-dependent supply of soluble (H3.3-H4) dimers to PML bodies pending deposition into chromatin. Genome Res. 2013; 23:440-51.

Dixon-McDougall T, Brown C. The making of a Barr body: the mosaic of factors that eXIST on the mammalian inactive X chromosome. Biochem Cell Biol. 2016; 94(1):5670.

Drane P, Ouararhni K, Depaux A, Shuaib M, Hamiche A. The death-associated protein DAXX is a novel histone chaperone involved in the replicationindependent deposition of H3.3. Genes Dev. 2010; 24:1253-65.

Elsässer SJ, Noh KM, Diaz N, Allis CD, Banaszynski LA. Histone H3.3 is required for endogenous retroviral element silencing in embryonic stem cells. Nature. 2015; 522(7555):240-4.

Escamilla-Del-Arenal M, da Rocha ST, Spruijt CG, Masui O, Renaud O, Smits $\mathrm{AH}$, Margueron R, Vermeulen $\mathrm{M}$, Heard $\mathrm{E}$. Cdyl, a new partner of the inactive $\mathrm{X}$ chromosome and potential reader of H3K27me3 and H3K9me2. Mol Cell Biol. 2013; 33(24):5005-20.

Francesco Ferrari, Artyom A. Alekseyenko, Peter J. Park, and Mitzi I. Kuroda. Transcriptional control of a whole chromosome: emerging models for dosage compensation. Nat Struct Mol Biol. 2014; 21(2): 118-25.

Gamble MJ, Kraus WL. Multiple facets of the unique histone variant macroH2A: from genomics to cell biology. Cell Cycle. 2010; 9(13):2568-74. Gilbert SL, Sharp PA. Promoter-specific hypoacetylation of X-inactivated genes. Proc Natl Acad Sci. 1999; 96:13825-30. 
Gimelbrant A, Hutchinson JN, Thompson BR, Chess A. Widespread monoallelic expression on human autosomes. Science. 2007; 318(5853):1136-40.

Goldberg A, Banaszynski L, Noh K, Lewis P, Elsaesser S, Stadler S, Dewell S, Law M, Guo X, Li X, Wen D, Chapgier A, DeKelver R, Miller J, Lee Y, Boydston E, Holmes M, Gregory P, Greally J, Rafii S, Yang C, Scambler P, Garrick D, Gibbons R, Higgs D, Cristea I, Urnov F, Zheng D, Allis C. Distinct factors control histone variant H3.3 localization at specific genomic regions. Cell. 2010; 140(5):678-91.

Graves JA. Sex chromosome specialization and degeneration in mammals. Cell. 2006; 124:901-14.

Graves JA. The evolution of mammalian sex chromosomes and the origin of sex determining genes. Philos Trans R Soc Lond B Biol Sci. 1995; 350(1333):30511.

Hasegawa Y, Brockdorff N, Kawano S, Tsutui KK, Tsutui KK, Nakagawa S, The matrix protein hnRNP $U$ is required for chromosomal localization of Xist RNA. Dev Cell. 2010; 19:469-76.

Hayflick $L$. The limited in vitro lifetime of human diploid cell strains. Exp Cell Res. 1965; 37:614-36. Hellman A, Chess A. Gene body-specific methylation on the active $X$ chromosome. Science. 2007; 315:1141-3.

Jacobs PA, Strong JA. A case of human intersexuality having a possible XXY sexdetermining mechanism. Nature. 1959; 183:302-03.

Jäger N, Schlesner M, Jones DT, Raffel S, Mallm JP, Junge KM, Weichenhan D, Bauer T, Ishaque N, Kool M, Northcott PA, Korshunov A, Drews RM, Koster J, Versteeg R, Richter J, Hummel M, Mack SC, Taylor MD, Witt H, Swartman B, Schulte-Bockholt D, Sultan M, Yaspo ML, Lehrach H, Hutter B, Brors B, Wolf S, Plass C, Siebert R, Trumpp A, Rippe K, Lehmann I, Lichter P, Pfister SM, Eils R. Hypermutation of the inactive $X$ chromosome is a frequent event in cancer. Cell. 2013; 155(3):567-81.

Jeon $Y$, Lee JT: YY1 tethers Xist RNA to the inactive $X$ nucleation center. Cell. $2011 ; 146: 119-33$.

Jullien J, Astrand C, Szenker E, Garrett N, Almouzni G, Gurdon J. HIRA dependent H3.3 deposition is required for transcriptional reprogramming following nuclear transfer to Xenopus oocytes. Epigenetics Chromatin. 2012; $5: 17$.

Kalantry S, Magnuson T. The Polycomb group protein EED is dispensable for the initiation of random X-chromosome inactivation. PLoS Genet. 2006; 2(5):e66.

Kalantry S. Recent advances in X-chromosome inactivation. J Cell Physiology. 2011; 226(7):1714-8. Kay GF, Penny GD, Patel D, Ashworth A, Brockdorff N, Rastan S. Expression of Xist during mouse development suggests a role in the initiation of X chromosome inactivation. Cell. 1993; 72:171-182.

Keniry A, Gearing LJ, Jansz N, Liu J, Holik AZ, Hickey PF, Kinkel SA, Moore DL, Breslin K, Chen K, Liu R, Phillips C, Pakusch M, Biben C, Sheridan JM, Kile BT, Carmichael C, Ritchie ME, Hilton DJ, Blewitt ME. Setdb1-mediated H3K9 
methylation is enriched on the inactive $X$ and plays a role in its epigenetic silencing. Epigenetics Chromatin. 2016; 9:16.

Kim D, Pertea G, Trapnell C, Pimentel H, Kelley R, Salzberg SL. TopHat2: accurate alignment of transcriptomes in the presence of insertions, deletions and genefusions. Genome Biol. 2013; 25;14(4):R36.

Kim KY, Hysolli E, Tanaka Y, Wang B, Jung YW, Pan X, Weissman SM, Park IH. $X$ Chromosome of female cells shows dynamic changes in status during human somatic cell reprogramming. Stem Cell Reports. 2014; 2(6):896-909.

Koboldt DC, Zhang Q, Larson DE, Shen D, McLellan MD, Lin L, Miller CA, Mardis ER, Ding L, Wilson RK. VarScan 2: somatic mutation and copy number alteration discovery in cancer by exome sequencing. Genome Res.2012; 22(3):568-76.

Koopman P, Gubbay J, Vivian N, Goodfellow P, Lovell-Badge R. Male development of chromosomally female mice transgenic for Sry. Nature. 1991; 351(6322):117-21.

Lana F, Shi Y. Histone H3.3 and cancer: A potential reader connection. Proc Natl Acad Sci. 2015; 112(22): 6814-19. Lee EA, Darrah LL, Coe EH. Dosage effects on morphological and quantitative traits in maize aneuploids. Genome. 1996; 39(5):898-908.

Leeb M, Wutz A. Ring1B is crucial for the regulation of developmental control genes and PRC1 proteins but not X inactivation in embryonic cells. J Cell Biol. 2007; 178(2):219-29.

Lengner CJ, Gimelbrant AA, Erwin JA, Cheng AW, Guenther MG, Welstead GG, Alagappan R, Frampton GM, Xu P, Muffat J, Santagata S, Powers D, Barrett CB, Young RA, Lee JT, Jaenisch R, Mitalipova M. Derivation of pre-X inactivation human embryonic stem cells under physiological oxygen concentrations. Cell. 2010; 141: 872-883.

Lessing D, Dial TO, Wei C, Payer B, Carrette LL, Kesner B, Szanto A, Jadhav A, Maloney DJ, Simeonov A, Theriault J, Hasaka T, Bedalov A, Bartolomei MS, Lee JT. A high-throughput small molecule screen identifies synergism between DNA methylation and Aurora kinase pathways for $X$ reactivation. Proc Natl Acad Sci. 2016; 113(50):14366-71.

Lewis PW, Muller MM, Koletsky MS, Cordero F, Lin S, Banaszynski LA, Garcia BA, Muir TW, Becher OJ, Allis CD. Inhibition of PRC2 activity by a gain-offunction H3 mutation found in pediatric glioblastoma. Science. 2013; 340:857861.

Lindroth AM, Plass C. Recurrent H3.3 alterations in childhood tumors. Nat Genet. 2013; 45(12):1413-4.

Lindsley DL, Sandler L, Baker BS, Carpenter AT, Denell RE, Hall JC, Jacobs PA, Miklos GL, Davis BK, Gethmann RC, Hardy RW, Steven AH, Miller M, Nozawa H, Parry DM, Gould-Somero M, Gould-Somero M..Segmental aneuploidy and the genetic gross structure of the Drosophila genome. Genetics. 1972; 71: 157-84.

Lock LF, Takagi N, Martin gr, Methylation of the Hprt gene on the inactive $X$ occurs after chromosome inactivation, Cell. 1987; 48:39-46. 
Lyon MF. Gene action in the X-chromosome of the mouse (Mus musculus L.). Nature. 1961; 190:372-73.

Lyon MF. Sex chromatin and gene action in the mammalian X-chromosome. Am J Hum Genet. 1962; 14:135-48.

Makhlouf M, Ouimette JF, Oldfield A, Navarro AP, Neuillet D, Rougeulle C. A prominent and conserved role for YY1 in Xist transcriptional activation. Nat Commun. 2014; 5:4878.

Margueron R, Reinberg D. The Polycomb complex PRC2 and its mark in life. Nature. 2011; 469(7330):343-9.

McHugh CA, Chen CK, Chow A, Surka CF, Tran C, McDonel P, Pandya-Jones A, Blanco M, Burghard C, Moradian A, Sweredoski MJ, Shishkin AA, Su J, Lander ES, Hess S, Plath K, Guttman M. The Xist IncRNA interacts directly with SHARP to silence transcription through HDAC3. Nature. 2015; 521: 232-36.

Mekhoubad S, Bock C, de Boer AS, Kiskinis E, Meissner A, Eggan K. Erosion of dosage compensation impacts human iPSC disease modeling. Cell Stem Cell. 2012; 10(5):595-609.

Mermoud JE, Costanzi C, Pehrson JR, Brockdorff N, Histone macroH2A1.2 relocates to the inactive $X$ chromosome after initiation and propagation of $X$ inactivation, J. Cell Biol. 1999; 147:1399-408.

Migeon BR, Jan de Beur S, Axelman J. Frequent derepression of G6PD and HPRT on the marsupial inactive $X$ chromosome associated with cell proliferation in vitro. Exp Cell Res. 1989; 182: 597-609.

Miller JL, Grant PA. The role of DNA methylation and histone modifications in transcriptional regulation in humans. Sub Cell Biochem. 2012; 61:289-317.

Minajigi A, Froberg JE, Wei C, Sunwoo H, Kesner B, Colognori D, Lessing D, Payer B, Boukhali M, Haas W, Lee JT. Chromosomes. A comprehensive Xist interactome reveals cohesin repulsion and an RNA-directed chromosome conformation. Science. 2015; 349:6245.

Minkovsky A, Sahakyan A, Bonora G, Damoiseaux R, Dimitrova E, Rubbi L, Pellegrini M, Radu CG, Plath K. A high-throughput screen of inactive $X$ chromosome reactivation identifies the enhancement of DNA demethylation by 5-aza-2'-dC upon inhibition of ribonucleotide reductase. Epigenetics Chromatin. 2015; 8:42.

Minkovsky A, Sahakyan A, Rankin-Gee E, Bonora G, Patel S, Plath K. The Mbd1Atf7ip-Setdb1 pathway contributes to the maintenance of $X$ chromosome inactivation. Epigenetics Chromatin. Epigenetics Chromatin. 2014; 26(7):12.

Moindroit B, Cerase A, Coker H, Masui O, Grijzenhout A, Pintacuda G, Schermelleh L, Nesterova TB, Brockdorff N. A pooled shRNA screen identifies Rbm15, Spen, and Wtap as factors required for Xist RNA-mediated silencing. Cell Rep. 2015; 12:562-72.

Monfort A, Di Minin G, Postlmayr A, Freimann R, Arieti F, Thore S, Wutz A. Identification of Spen as a crucial factor for Xist function through forward genetic screening in haploid embryonic stem cells. Cell Rep. 2015; 12:554-61. 
Moreira de Mello, Joana. Estudos da inativação do cromossomo X em humanos: iniciação e imprinting. [Tese (Doutorado em Biologia)] - Instituto de Biociências da USP. Departamento de Genética e Biologia Evolutiva. Universidade São Paulo, São Paulo; 2015.

Morey C, Avner P. Genetics and epigenetics of the X chromosome. Ann N Y Acad Sci. 2010;1214:E18-33.

Muller HJ. A gene for the fourth chromosome of Drosophila. J Exp Zool. 1914; 17:325-36.

Naldini L, Blömer U, Gallay P, Ory D, Mulligan R, Gage FH, Verma IM, Trono D. In vivo gene delivery and stable transduction of nondividing cells by a lentiviral vector. Science. 1996; 272(5259):263-7.

Ng K, Pullirsch D, Leeb M, Wutz A. Xist and the order of silencing. EMBO Rep. 2007; 8:34-39.

$\mathrm{Ng} \mathrm{RK}$, Gurdon JB. Epigenetic memory of an active gene state depends on histone H3.3 incorporation into chromatin in the absence of transcription. Nat Cell Biol. 2008; 10(1):102-9.

Ngo VN, Davis RE, Lamy L, Yu X, Zhao H, Lenz G, Lam LT, Dave S, Yang L, Powell J, Staudt LM. A loss-of-function RNA interference Screen for Molecular Targets in Cancer. Nature. 2006; 441(7089):106-110.

Nguyen DK, Disteche CM. Dosage compensation of the active X chromosome in mammals. Nat Genet. 2006; 38:47-53.

Ohhata T, Tachibana M, Tada M, Tada T, Sasaki H, Shinkai Y, Sado T. Xinactivation is stably maintained in mouse embryos deficient for histone methyl transferase G9a. Genesis. 2004; 40(3):151-6.

Ohno S. Evolution of sex chromosomes in mammals. Annu Rev Genet. 1969; 3:495- 524.

Okamoto I, Otte AP, Allis CD, Reinberg D, Heard E, Epigenetic dynamics of imprinted $X$ inactivation during early mouse development, Science. 2004; 303(5658):644-9.

Panning B, Dausman J, Jaenisch R. X Chromosome Inactivation Is Mediated by Xist RNA Stabilization. Cell. 1997; 90(5): 907-16.

Pasque V, Radzisheuskaya A, Gillich A, Halley-Stott RP, Panamarova M, ZernickaGoetz M, Surani MA, Silva JC. Histone variant macroH2A marks embryonic differentiation in vivo and acts as an epigenetic barrier to induced pluripotency. J Cell Sci. 2012; 125:6094-104.

Pastor WA, Chen D, Liu W, Kim R, Sahakyan A, Lukianchikov A, Plath K, Jacobsen SE, Clark AT. Naive Human Pluripotent Cells Feature a Methylation Landscape Devoid of Blastocyst or Germline Memory. Cell Stem Cell. 2016; 18(3): 323-29.

Paterno GD, Adra CN, Mcburney MW. X Chromosome reactivation in mouse embryonal carcinoma cells. Mol Cell Biol. 1985; 2705-12. Payer B, Lee JT. X 
Chromosome Dosage Compensation: How Mammals Keep the Balance. Annu.Rev.Genet. 2008; 42:733-72.

Pehrson JR, Changolkar LN, Costanzi C, Leu NA. Mice without macroH2A histone variants. Mol Cell Biol. 2014; 34(24): 4523-33.

Pfaffl M. A new mathematical model for relative quantification in real-time RTPCR. Nucleic Acids. 2001; 29(9): 45.

Pinter SF. A Tale of Two Cities: How Xist and its partners localize to and silence the bicompartmental X. Semin Cell Dev Biol. 2016; 56:19-34.

Plath K, Fang J, S.K. Mlynarczyk-Evans, R. Cao, K.A. Worringer, H. Wang, et al., Role of histone H3 lysine 27 methylation in $X$ inactivation, Science. 2003; 300(5616):131-5.

Poeschla E, Wong-Staal F, Looney D. Efficient transduction of nondividing cells by feline immunodeficiency virus lentiviral vectors. Nat Med. 1998; 4:354-57.

Rai TS, Puri A, McBryan T, Hoffman J, Tang Y, Pchelintsev NA, van Tuyn J, Marmorstein R, Schultz DC, Adams PD. Human CABIN1 is a functional member of the human HIRA/UBN1/ASF1a histone H3.3 chaperone complex. Mol Cell Biol. 2011; 31:4107-18.

Ray-Gallet D, Woolfe A, Vassias I, Pellentz C, Lacoste N, Puri A, Schultz DC, Pchelintsev NA, Adams PD, Jansen LE, Almouzni G. Dynamics of histone H3 deposition in vivo reveal a nucleosome gap-filling mechanism for $\mathrm{H} 3.3$ to maintain chromatin integrity. Mol Cell. 2011; 44(6):928-41.

Rice WR. Evolution of the $Y$ sex chromosome in animals. Bioscience. 1996; 46: 331-43.

Richardson AL, Wang ZC, De Nicolo A, Lu X, Brown M, Miron A, Liao X, Iglehart JD, Livingston DM, Ganesan S. X chromosomal abnormalities in basal-like human breast cancer. Cancer Cell. 2006; 9(2): 121-32.

Ricketts MD, Frederick B, Hoff H, Tang Y, Schultz DC, Singh Rai T, Grazia Vizioli M, Adams PD, Marmorstein R. Ubinuclein-1 confers histone H3.3-specificbinding by the HIRA histone chaperone complex. Nat Commun. 2015; 6:7711.

Sack LM, Davoli T, Xu Q, Li MZ, Elledge SJ. Sources of Error in Mammalian Genetic Screens. G3 (Bethesda). 2016; 6(9): 2781-2790.

Sado T, Fenner MH, Tan SS, Tam P, Shioda T, Li E. X inactivation in the mouse embryo deficient for Dnmt1: distinct effect of hypomethylation on imprinted and random X inactivation. Dev Biol. 2000; 225(2): 294-303.

Sado T, Okano M, Li E, Sasaki H. De novo DNA methylation is dispensable for the initiation and propagation of $X$ chromosome inactivation. Development. 2004; 131:975-82.

Sarkar MK, Gayen S, Kumar S, Maclary E, Buttigieg E, Hinten M, Kumari A, Harris C, Sado T, Kalantry S. An Xist-activating antisense RNA required for Xchromosome inactivation. Nat Commun. 2015; 6:8564. 
Shalem O, Sanjana NE, Hartenian E, Shi X, Scott DA, Mikkelsen TS, Heckl D, Ebert BL, Root DE, Doench JG, Zhang F. Genome-scale CRISPR-Cas9 knockout screening in human cells. Science. 2014; 343:84-87.

Siegel JJ \& Amon A. New insights into the troubles of aneuploidy. Annu Rev Cell Dev Biol. 2012; 28:189-214.

Silva W, Mak I, Zvetkova R, Appanah T.B. Nesterova, Z. Webster, et al., Establishment of histone $\mathrm{h} 3$ methylation on the inactive $\mathrm{X}$ chromosome requires transient recruitment of Eed-Enx1 polycomb group complexes, Dev Cell. 2003; $4: 481-95$.

Sims D, Mendes-Pereira AM, Frankum J, Burgess D, Cerone MA, Lombardelli C, Mitsopoulos C, Hakas J, Murugaesu N, Isacke CM, Fenwick K, Assiotis I, Kozarewa I, Zvelebil M, Ashworth A, Lord CJ. High-throughput RNA interference screening using pooled shRNA libraries and next generation sequencing. Genome Biol. 2011; 12(10):R104.

Stingele S, Stoehr G, Peplowska K, Cox J, Mann M, Storchova Z. Global analysis of genome, transcriptome and proteome reveals the response to aneuploidy in human cells. Mol Syst Biol. 2012; 8:608.

Straub T, Becker PB. Dosage compensation: the beginning and end of generalization. NatRev.Genet. 2007; 8:47-57.

Strezoska Ž, Licon A, Haimes J, Spayd KJ, Patel KM, Sullivan K, Jastrzebski K, Simpson KJ, Leake D, van Brabant Smith A, Vermeulen A. Optimized PCR conditions and increased shRNA fold representation improve reproducibility of pooled shRNA screens. PLoS One. 2012; 7: e42341.

Sun S, Del Rosario BC, Szanto A, Ogawa AY, Jeon Y, Lee JT. Jpx RNA activates Xist by evicting CTCF, Cell. 2013; 153: 1537-1551.

Takagi N, Sasaki M. Preferential inactivation of the paternally derived $X$ chromosome in the extraembryonic membranes of the mouse. Nature. 1975; 256:640-42.

Torres EM, Sokolsky T, Tucker CM, Chan LY, Boselli M, Dunham MJ, Amon A. Effects of aneuploidy on cellular physiology and cell division in haploid yeast. Science. 2007; 317:916-24.

Vallot C, Huret C, Lesecque Y, Resch A, Oudrhiri N, Bennaceur-Griscelli A, Duret $\mathrm{L}$, Rougeulle $\mathrm{C}$. XACT, a long noncoding transcript coating the active $\mathrm{X}$ chromosome in human pluripotent cells. Nat. Genet. 2013; 45:239-41.

Vallot C, Ouimette JF, Makhlouf M, Féraud O, Pontis J, Côme J, Martinat C, Bennaceur-Griscelli A, Lalande $\mathrm{M}$, Rougeulle $\mathrm{C}$. Erosion of $\mathrm{X}$ Chromosome Inactivation in Human Pluripotent Cells Initiates with XACT Coating and Depends on a Specific Heterochromatin Landscape. Cell Stem Cell. 2015; 16(5):533-46.

Vasques LR, Schoof CRG, Botelho EL. MicroRNAs: A New Paradigm for Gene Regulation. In: Gaur RK; Gafni Y; Sharma P; Gupta VK. (Org.). RNAi Technology. 1ed.Enfield, New Hampshire: Science Publishers. 2011; 1:135-53. 
Veitia RA, Veyrunes F, Bottani S, Birchler JA. X chromosome inactivation and active $X$ upregulation in therian mammals: facts, questions, and hypotheses. $J$ Mol Cell Biol. 2015; 7(1):2-11.

Vergani, Naja. Triagem funcional de genes envolvidos no processo de manutenção da inativação do cromossomo $X$ em humanos. [Tese (Doutorado em Biologia)] - Instituto de Biociências da USP. Departamento de Genética e Biologia Evolutiva. Universidade São Paulo, São Paulo; 2014.

Watson JM, McKay LM, Marshall Graves JA. Genome instability in interspecific cell hybrids II. Aminopterin resistance and gene amplification in lines arising from fusions of cells from divergent mammalian species. J Genet. 1988; 67(2):75-86.

Yang TP, Stout JT, Konecki DS, Patel PI, Alford RL, Caskey CT. Spontaneous Reversion of Novel Lesch-Nyhan Mutation by HPRT Gene Rearrangement. Som Cell Mol Genet. 1988; 14(3):293-303.

Yasukochi Y, Maruyama O, Mahajan MC, Padden C, Euskirchen GM, Schulz V, Hirakawa H, Kuhara S, Pan XH, Newburger PE. X chromosome-wide analyses of genomic DNA methylation states and gene expression in male and female neutrophils. Proc Natl Acad Sci. 2010; 107: 3704-09.

Yildirim E, Kirby JE, Brown DE, Mercier FE, Sadreyev RI, Scadden DT, Lee JT. Xist RNA Is a Potent Suppressor of Hematologic Cancer in Mice. Cell. 2013; 152:727-42.

Zhang B, Metharom P, Jullie H, Ellem KA, Cleghorn G, West MJ, Wei MQ. The significance of controlled conditions in lentiviral vector titration and in the use of multiplicity of infection (MOI) for predicting gene transfer events. Genet Vacc Ther. 2004; 2:6.

Zhang LFF, Huynh KD, Lee JT, Perinucleolar targeting of the inactive X during S phase: evidence for a role in the maintenance of silencing, Cell. 2007; 129:693706.

Zhang R, Chen W, Adams PD. Molecular dissection of formation of senescence associated heterochromatin foci. Mol Cell Biol. 2007; 27(6):2343-58. 


\section{ANEXOS}

\section{ANEXO I}

\section{Resumo do Plano Experimental de RNA-Seq adotado para as análises de expressão alelo-específica}

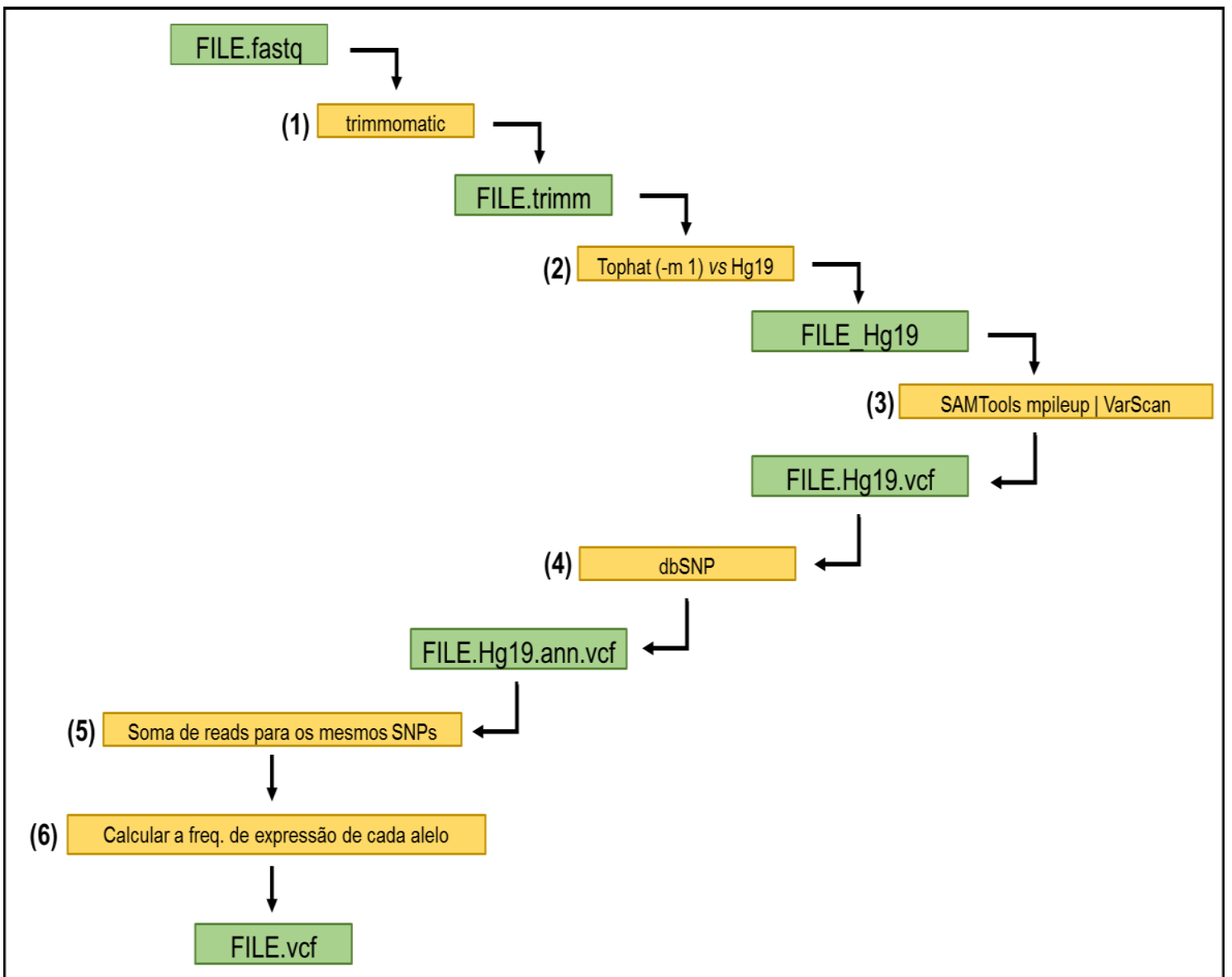

Diagrama do plano de trabalho. Estão apresentadas as etapas desde a formatação das reads até a obtenção do arquivo final com os SNPs anotados. Os números entre parêntese fazem referência ao subitem com maiores explicações dos parâmetros utilizados. Fonte: Modificado de Moreira de Mello, 2015.

\section{(1) Trimmomatic}

\subsection{Controle de qualidade das reads}

Diagrama do plano de trabalho. Estão apresentadas as etapas desde a formatação das reads até a obtenção do arquivo final com os SNPs anotados. Os números entre parêntese fazem referência ao subitem com maiores explicações dos parâmetros utilizados. Fonte: Modificado de Mello, 2015. 
- Q-score maior ou igual a 3

1.2 Remoção dos adaptadores e seqüências de baixa qualidade

- Linha de comando utilizada:

java -jar trimmomatic-0.33.jar $\mathrm{PE}$-phred33 $<\$ 1 \backslash$ 1.fastq $><\$ 1 \backslash 2$.fastq $>$ $<\$ 1 \backslash 1$ 1_paired.fq.gz $><\$ 1 \backslash 1$ 1_unpaired.fq.gz $><\$ 1 \backslash 2$ _paired.fq.gz $>$ $<\$ 1 \backslash 2$ _unpaired.fq.gz> LEADING:3 TRAILING:3 SLIDINGWINDOW:4:15 MINLEN:36

Parâmetros utilizados:

- Remoção do adaptador (ILLUMINACLIP):TruSeq3-PE-2.fa:2:30:10

- Remoção das primeiras 15 bases (HEADCROP):15

- Limiar de corte da região 5' (LEADING): 3;

- Limiar de corte da região 3' (TRAILING): 3;

- Tamanho da janela deslizante e qualidade média mínima de corte (SLIDINGWINDOW): 4: 15;

- Tamanho mínimo do fragmento resultante (MINLEN): 36; adicionando-se a opção PE (paired-end) e -phred33.

1.3 Reads Obtidos

\begin{tabular}{|l|c|c|}
\cline { 2 - 3 } \multicolumn{1}{c|}{} & \multicolumn{2}{c|}{ Amostra } \\
\cline { 2 - 3 } \multicolumn{1}{c|}{} & S2 & S3 \\
\hline Input Read Pairs & 69889873 & 59705211 \\
\hline Both Surviving & $67947379(97,22 \%)$ & $58308076(97,66 \%)$ \\
\hline Forward Only Surviving & $1445653(2,07 \%)$ & $958571(1,61 \%)$ \\
\hline Reverse Only Surviving & $319917(0,46 \%)$ & $312483(0,52 \%)$ \\
\hline Dropped & $176924(0,25 \%)$ & $126081(0,21 \%)$ \\
\hline
\end{tabular}

(2) TopHat

Alinhamento contra genoma de referência (Hg19)

- Linha de comando utilizada:

tophat --bowtie1 -N 3 --read-edit-dist 3 -g 1 --library-type fr-unstranded --nonovel-juncs -G <UCSC_hg19_refGene.gtf> $><\$ 1.0 u t>$ > Hg19_index> $<\$ 1 \backslash 1 \_$paired.fq $><\$ 1 \backslash 2 \_$paired.fq $>$

*O FILE de saída contem só as reads q alinharam uma única vez no genoma

(3) SAMTools e VarScan

- Linha de comandos utilizados: 
samtools mpileup -B -f < Hg19.fa $>$-q $1<$ FILE.bam $>$ | java -jar

VarScan.v2.3.7.jar mpileup2cns --output-vcf <FILE_Hg19.vcf0>.

grep -v "\.^." FILE_Hg19.vcf0 > FILE_Hg19.vcf

\section{(4) Anotação de possíveis variantes}

Alinhamento contra banco de referência (dbSNPnnn)

- Programa utilizado (Feito pela profa. Maria Vibranovski):

insert_rs_toDB_new.pl

- Comando utilizado:

perl insert_rs_toDB_new.pl -r 1_FILE_L005_female.vcf -s dbSNP -o

FILE_ann.vcf

(5) Soma de reads que cobrem a região de um mesmo SNP

- Mínimo 8 reads por SNP

(6) Calcular a frequência de expressão de cada alelo

- Contar o número de reads para cada alelo dos SNP anotados (limiares para ser considerado bialélico entre 0.85 e 0.15 ).

${ }^{*}$ Os nomes dos arquivos de entrada e saída aqui são genéricos (FILE) e variaram de acordo com a identificação da amostra. 


\section{ANEXO II}

Lista de genes com expressão monoalélica na amostra S3 que mostraram expressão bialélica após tratamento nos cromossomos autossômicos

\begin{tabular}{|c|c|c|c|c|c|c|c|c|c|c|c|c|c|c|c|c|c|c|c|c|c|c|}
\hline Chr 1 & SLC35E2B & NBPF15 & NBPF3 & NBPF9 & CROCC & DDAH1 & GPR157 & HHAT & PDE4DIP & TMEM81 & GAS5 & CPSF3L & RPL11 & SERBP1 & SRP9 & FAM72D & NBPF1 & PPIAL4G & FMN2 & GBP3 & SEPN1 & SOAT1 \\
\hline Chr 2 & |TGB1BP1 & LIMS1 & BOK & CCNYL1 & COL6A3 & RANBP2 & ANKRD36 & & & & & & & & & & & & & & & \\
\hline Chr 3 & DHFRL1 & EHHADH & TMEM44 & \begin{tabular}{|l|} 
IFT122 \\
\end{tabular} & NDUFB4 & & & & & & & & & & & & & & & & & \\
\hline Chr 4 & TMEM128 & CRIPAK & LIMCH1 & UFSP2 & COX18 & & & & & & & & & & & & & & & & & \\
\hline Chr 5 & CHSY3 & $\operatorname{IRX2}$ & MRPL36 & PCDHB2 & SFXN1 & PCDHB8 & & & & & & & & & & & & & & & & \\
\hline Chr 6 & HLA-A & HLA-B & HLA-C & MICAL1 & MICB & FAM120B & RPL10A & RPS10 & PNISR & RUNX2 & SIM1 & & & & & & & & & & & \\
\hline Chr 7 & MAGI2 & & & & & & & & & & & & & & & & & & & & & \\
\hline Chr 8 & FAM86B1 & TNFRSF $10 \mathrm{C}$ & ANK1 & CTSB & FGFR1 & LY6K & TOX & ZBTB10 & CTSB & LYGK & TRPS1 & & & & & & & & & & & \\
\hline \begin{tabular}{|l|} 
Chr 9 \\
\end{tabular} & RPS6 & TPM2 & TTLL11 & VLDLR & CNTRL & INIP & PHYHD1 & & & & & & & & & & & & & & & \\
\hline Chr 10 & AGAP4 & EXOC6 & PDZD8 & PDZD8 & ARHGAP22 & FRMD4A & STK32C & APBB1IP & APBB1IP & FUT11 & KAT6B & KLF6 & SAR1A & SIRT1 & & & & & & & & \\
\hline Chr 11 & APLP2 & DCHS1 & MCAM & PLEKHA7 & CCDC84 & MAML2 & RPS3 & & & & & & & & & & & & & & & \\
\hline Chr 12 & NUDT4 & STX2 & EMG1 & RPL6 & ХРОТ & & & & & & & & & & & & & & & & & \\
\hline Chr 13 & NBEA & WASF3 & & & & & & & & & & & & & & & & & & & & \\
\hline \begin{tabular}{|l|} 
Chr 14 \\
\end{tabular} & FOXN3 & PACS2 & PYGL & AHNAK2 & SAMD4A & L3HYPDH & & & & & & & & & & & & & & & & \\
\hline Chr 15 & GOLGA8A & UBE2Q2 & & & & & & & & & & & & & & & & & & & & \\
\hline Chr 16 & KIAA0513 & PKD1 & ZNF213 & FLYWCH1 & SLC9A3R2 & SULT1A1 & FOXL1 & VAT1L & LONP2 & & & & & & & & & & & & & \\
\hline \begin{tabular}{|l|} 
Chr 17 \\
\end{tabular} & KLHL11 & NPTX1 & RPTOR & SLC43A2 & SLFN5 & SLFN13 & DCAF7 & OGFOD3 & RPL23 & & & & & & & & & & & & & \\
\hline Chr 18 & HSBP1L1 & LAMA3 & & & & & & & & & & & & & & & & & & & & \\
\hline Chr 19 & ZNF536 & ZNF880 & MKNK2 & NOTCH3 & PTPRS & RPS15 & SLC27A5 & SSC5D & ZNF667 & PSG11 & PSG2 & PSG8 & PSG9 & TRPM4 & RPL13A & & & & & & & \\
\hline Chr 20 & BLCAP & $\mathrm{CDH} 4$ & & & & & & & & & & & & & & & & & & & & \\
\hline Chr 21 & YBEY & & & & & & & & & & & & & & & & & & & & & \\
\hline Chr 22 & APOL1 & PLXNB2 & APOL6 & FAM118A & & & & & & & & & & & & & & & & & & \\
\hline
\end{tabular}

*Em azul escuro, genes que já foram descritos na literatura como genes monoalélicos em humanos. Em azul claro, genes que ainda não foram descritos para humanos. 


\section{ANEXO III}

Lista de genes ligados ao cromossomo $X$ que apresentaram uma expressão aumentada significativa estadisticamente na amostra $\mathbf{S 2}$ ao compará-la com a amostra S3.

\begin{tabular}{|c|l|l|}
\hline $\begin{array}{c}\text { Balaton } \\
\text { consensus }\end{array}$ & Nome do gene & \multicolumn{1}{|c|}{ Função Relacionada } \\
\hline S & IM2 & Manutenção celular \\
\hline S & OTUD5 & Manutenção celular \\
\hline S & GRIPAP1 & Manutenção celular \\
\hline Mostly S & TFE3 & Remodelador de cromatina \\
\hline S & PRAF2 & Manutenção celular \\
\hline S & WDR45 & Manutenção celular \\
\hline Mostly S & GPKOW & Remodelador de cromatina \\
\hline S & PLP2 & Manutenção celular \\
\hline S & PRICKLE3 & Manutenção celular \\
\hline S & CCDC22 & Marcador de doença ligada ao X \\
\hline S & PPP1R3F & Manutenção celular \\
\hline- & USP27X-AS1 & IncRNA \\
\hline S & USP27X & Manutenção celular \\
\hline S & CLCN5 & Manutenção celular \\
\hline S & NUDT10 & Manutenção celular \\
\hline S & NUDT11 & Manutenção celular \\
\hline S & GSPT2 & Manutenção celular \\
\hline S & MAGED1 & Relacionado com câncer \\
\hline S & MAGED4B & Relacionado com câncer \\
\hline S & MAGED4 & Relacionado com câncer \\
\hline S & FAM156B & Remodelador de cromatina \\
\hline S & FAM156A & Remodelador de cromatina \\
\hline Mostly S & GPR173 & Manutenção celular \\
\hline S & TSPYL2 & Remodelador de cromatina \\
\hline- & RP11-258C19.4 & Pseudogene \\
\hline - & RP11-258C19.7 & IncRNA \\
\hline Mostly E & KDM5C & Remodelador de cromatina \\
\hline Mostly E & IQSEC2 & Manutenção celular \\
\hline Mostly E & SMC1A & Remodelador de cromatina \\
\hline Mostly S & HSD17B10 & Manutenção celular \\
\hline Mostly S & HUWE1 & Relacionado com doença ligada ao X \\
\hline S & PHF8 & Relacionado com doença ligada ao X \\
\hline S & FAM120C & Relacionado com Autismo \\
\hline S & TSR2 & Manutenção celular- proliferação celular \\
\hline Mostly S & FGD1 & Relacionado com doença ligada ao X \\
\hline Mostly S & GNL3L & Manutenção celular- apoptose \\
\hline Mostly S & MAGED2 & Relacionado com câncer \\
\hline & & \\
\hline
\end{tabular}




\begin{tabular}{|c|c|c|}
\hline Mostly S & TRO & Manutenção celular \\
\hline $\mathrm{S}$ & APEX2 & Remodelador de cromatina \\
\hline $\mathrm{S}$ & FAM104B & Não descrito \\
\hline $\mathrm{S}$ & MAGEH1 & Manutenção celular \\
\hline Mostly S & RRAGB & Manutenção celular \\
\hline S & KLF8 & Remodelador de cromatina \\
\hline $\mathrm{S}$ & UBQLN2 & Manutenção celular \\
\hline- & RP11-622K12.1 & No descrito \\
\hline S & UQCRBP1 & Pseudogene \\
\hline Mostly S & SPIN3 & Relacionado com câncer \\
\hline Mostly S & SPIN2B & Manutenção celular \\
\hline S & SPIN2A & Manutenção celular \\
\hline S & ZXDB & Remodelador de cromatina \\
\hline S & ZXDA & Remodelador de cromatina \\
\hline Discordant & PIN4 & Remodelador de cromatina \\
\hline $\mathrm{S}$ & ERCC6L & Manutenção celular \\
\hline Mostly E & RPS4X & Manutenção celular \\
\hline S & HDAC8 & Remodelador de cromatina \\
\hline Mostly S & PHKA1 & Manutenção celular \\
\hline S & $\mathrm{CHIC} 1$ & Não descrito \\
\hline Mostly S & XIST & Remodelador de cromatina \\
\hline $\mathrm{E}$ & JPX & Remodelador de cromatina \\
\hline - & RP13-216E22.4 & IncRNA \\
\hline - & RP3-368A4.5 & IncRNA \\
\hline Mostly S & SLC16A2 & Manutenção celular \\
\hline $\mathrm{S}$ & RLIM & Relacionado com doença ligada ao X \\
\hline Mostly S & ABCB7 & Manutenção celular \\
\hline Mostly S & UPRT & $\begin{array}{l}\text { Relacionado com metabolismo de } \\
\text { nucleotídeos }\end{array}$ \\
\hline - & TTC3P1 & Pseudogene \\
\hline $\mathrm{s}$ & PBDC1 & Não descrito \\
\hline Discordant & MAGEE1 & Relacionado com doença ligada ao X \\
\hline $\mathrm{S}$ & ATRX & Remodelador de cromatina \\
\hline $\mathrm{S}$ & MAGT1 & Relacionado com doença ligada ao X \\
\hline VE & COX7B & Manutenção celular \\
\hline Mostly S & ATP7A & Manutenção celular \\
\hline
\end{tabular}

* Classificação de genes ligados ao cromossomo X segundo Balaton: S(submetido), Mostly S (Maiormente submetido), E (Escapa), Mostly E (Maiormente escapa), VE (Escape variável, dependente do tipo de tecido, espécie, etc.), Discordant (Informação na literatura discordante ao respeito do seu estado no X). 